\title{
The use of South African botanical species for the control of blood
}

\section{sugar}

\author{
I.E. Cock ${ }^{\mathrm{a}, \mathrm{b}}$, N. Ndlovu ${ }^{\mathrm{c}}$, S.F. Van Vuuren ${ }^{\mathrm{c}^{*}}$
}

a School of Environment and Science, Nathan Campus, Griffith University, 170 Kessels Rd, Nathan, Queensland 4111, Australia

${ }^{b}$ Environmental Futures Research Institute, Nathan Campus, Griffith University, 170 Kessels Rd, Nathan, Queensland 4111, Australia

${ }^{c}$ Department of Pharmacy and Pharmacology, Faculty of Health Sciences, University of the Witwatersrand, Parktown, Gauteng 2193, South Africa

${ }^{*}$ Corresponding author.

E-mail address: sandy.vanvuuren@,wits.ac.za (S. Van Vuuren)

\begin{abstract}
Ethnopharmacological relevance: Diabetes mellitus (DM) is one of the most prevalent diseases globally and is of considerable concern to global health. Approximately 425 million people are estimated to have DM globally and this is predicted to increase to $>642$ million by 2040. Whilst the prevalence of DM in South Africa is slightly lower than the global average, it is expected to rise rapidly in future years as more South Africans adopt a high calorie "Westernised" diet. Traditional medicines offer an alternative for the development of new medicines to treat DM and the usage of South African plants is relatively well documented.
\end{abstract}


Aim of the study: To critically review the literature on the anti-diabetic properties of South African plants and to document plant species used for the treatment of DM. Thereafter, a thorough examination of the related research will highlight where research is lacking in the field.

Materials and methods: A review of published ethnobotanical books, reviews and primary scientific studies was undertaken to identify plants used to treat DM in traditional South African healing systems and to identify gaps in the published research. The study was nonbiased, without taxonomic preference and included both native and introduced species. To be included, species must be recorded in the pharmacopeia of at least one South African ethnic group for the treatment of DM.

Results: One hundred and thirty-seven species are recorded as therapies for DM, with leaves and roots most commonly used. The activity of only 43 of these species have been verified by rigorous testing, although relatively few studies have examined the mechanism of action.

Conclusion: Despite relatively extensive ethnobotanical records and a diverse flora, the antidiabetic properties of South African medicinal plants is relatively poorly explored. The efficacy of most plants used traditionally to treat DM are yet to be verified and few mechanistic studies are available. Further research is required in this field.

Keywords:

Diabetes, hyperglycaemia, glycosylated haemoglobin, blood glucose concentration, traditional medicine, ethnomedicine, South African plants 


\section{Contents}

1. Introduction

1.1. Classes of diabetes

1.2. Causes of diabetes mellitus

1.3. Symptoms of diabetes mellitus

1.4. Current treatment options for diabetes mellitus and role of alternate therapies

1.5. The use of medicinal plants in diabetes treatment

2. An overview of diabetes mellitus in South Africa

3. Materials and methods

4. South African medicinal plants traditionally used to treat diabetes mellitus

5. Scientific studies into the anti-diabetes mellitus activity of South African plants

6. Discussion and conclusions

Abbreviations: DM, diabetes mellitus; (GDM), gestational diabetes mellitus; WHO, The World Health Organisation; UTIs, urinary tract infections.

\section{Introduction}

Diabetes is a chronic metabolic disease that manifests as hyperglycaemia over prolonged periods. The symptoms of diabetes include frequent urination as well as increased thirst and hunger. If not effectively treated, the elevated blood glucose levels can induce many metabolic and physiological complications including ketoacidosis and serious damage to cardiac, neuronal, hepatic and renal tissue, as well as to the eyes and blood vessels. The disease 
can arise either through the inability of the pancreas to produce functional insulin, or from an inability to effectively use the insulin that is produced.

Whilst historically, diabetes is well-known, modern lifestyles with their high energy diets and low exercise levels have resulted in a dramatic increase in diabetes associated diseases. The World Health Organisation (WHO) now considers the global burden of diabetes to be of considerable concern (WHO, 2019). In 1980, the WHO estimated the cases of diabetes mellitus (DM) to be 108 million worldwide (WHO, 2019). By 2017, this figure had increased dramatically to 425 million people with diabetes, an increase of almost $400 \%$ across that period. This figure equates to approximately $9 \%$ of the adult population over 18 years of age globally, with equal representation from both males and females. The increasing rates of diabetes have been most notable in low-middle income developing countries, with rates of increase substantially higher than the global average. Of further concern, the number of people suffering from DM is expected to continue to rise at similar rates and it is estimated that $>642$ million people will have DM by 2040 (International Diabetes Federation, 2015). Notably, all these figures document the reported number of cases of DM. As many cases remain unreported, particularly in the early phases, the prevalence of diabetic related disease may be substantially under-estimated.

Not only does the disease cause serious morbidities including blindness, coronary and renal disease, stroke and often the need for limb amputation, DM more than doubles an individual's risk of early death (WHO, 2019). Indeed, it was estimated in 2017 that DM was directly responsible for 3.2-5.0 million deaths globally (International Diabetes Federation, 2017). Notably, substantial further deaths that are not directly attributed with DM also result from hyperglycaemia. Indeed, high blood sugar levels were noted in 2.12 million further deaths not attributed to DM in 2012 (WHO, 2019). With current trends, the condition is anticipated to become one of the world's leading causes of disability and death in the next 25 years (Malviya 
et al., 2010). The high levels of morbidity and mortality caused by DM also place an increasing burden on the health care system, with the global cost of DM estimated to be US\$727 billion in 2017 (International Diabetes Federation, 2017). These costs are expected to increase in parallel with the projected increases in DM levels in the future.

In South Africa, the prevalence of DM is estimated to be between $4 \%$ and $6 \%$ of the adult population (Deutschländer et al., 2009), making it similar to, but slightly below the global average. Furthermore, DM was recorded as the fifth leading cause of death in the country (WHO, 2016). Several reports have highlighted the higher levels of mortality from diabetes amongst black South African populations, compared with other South African ethnic groups (Erasto et al., 2005). Women are of the highest risk group based in part towards sociocultural aspects (Goedecke et al., 2017). It is likely that the prevalence amongst black South Africans will continue to increase at greater rates than the South African average as the economic position of the population improves and more people adopt higher energy diets. In the face of this growing epidemic, new safe and efficient DM treatments are urgently required (Mbanya et al., 2010). A re-examination of traditional therapeutic options is promising for the development of new therapies. Whilst reviews are available on medicinal plants for the control of blood sugar from various countries and geographical areas (Table 1) there has been very little consolidated literature of natural product leads for DM from South Africa and the neighbouring countries. This review focuses on these aspects with the aim to 1.) Provide a background of DM, the treatment options and the need to examine natural products as alternative treatment options. 2.) Document the medicinal plants used in South Africa for the control of blood sugar and lastly 3.) Correlate the scientific findings of traditionally used plants in order to identify frequently used plant species with anti-DM potential and hence stimulate further research in this field. 


\section{Table 1}

Reviews on diabetes

\begin{tabular}{|c|c|c|c|c|}
\hline Subject matter & $\begin{array}{l}\text { Geographical } \\
\text { focus }\end{array}$ & $\begin{array}{l}\text { Number of } \\
\text { plant species } \\
\text { covered }\end{array}$ & Recommendations & Authors \\
\hline $\begin{array}{l}\text { In vivo anti-diabetic } \\
\text { activity }\end{array}$ & South Africa & 32 & $\begin{array}{l}\text { 1) Identified a number of promising taxa } \\
\text { for further investigation. }\end{array}$ & Afolayan and Sunmonu, 2010 \\
\hline $\begin{array}{l}\text { Herbal medicines } \\
\text { for diabetes }\end{array}$ & $\begin{array}{l}\text { Global } \\
\text { perspective }\end{array}$ & 35 & $\begin{array}{l}\text { 1) Isolation and identification of active } \\
\text { constituents. } \\
\text { 2) Preparation of standardized doses. } \\
\text { 3) Provide Evidence-Based alternative } \\
\text { medicine. }\end{array}$ & Upendra Rao et al., 2010 \\
\hline $\begin{array}{l}\text { Antidiabetes } \\
\text { activity of African } \\
\text { medicinal plants }\end{array}$ & Africa & 42 & $\begin{array}{l}\text { 1) Novel therapeutic agents for diabetes } \\
\text { management should be further } \\
\text { investigated. }\end{array}$ & Ndip et al., 2013 \\
\hline
\end{tabular}




\begin{tabular}{|l|l|l|l|l|}
\hline Subject matter & Geographical & Number of & Recommendations & Authors \\
plant species & covered & & & \\
plants with & Africa & 185 & $1)$ Governmental support in research. & Mohammed et al., 2014 \\
antidiabetic & & & 1) Isolation, purification and & Mohammed et al., 2015 \\
potential & India and Africa & 9 & characterization of the bioactive & \\
\hline $\begin{array}{l}\text { Lesser known } \\
\text { medicinal plants for }\end{array}$ & & & compounds. & \\
diabetes & & & & \\
\hline
\end{tabular}




\begin{tabular}{|c|c|c|c|c|}
\hline Subject matter & $\begin{array}{l}\text { Geographical } \\
\text { focus }\end{array}$ & $\begin{array}{l}\text { Number of } \\
\text { plant species } \\
\text { covered }\end{array}$ & Recommendations & Authors \\
\hline $\begin{array}{l}\text { Medicinal plants } \\
\text { used for } \\
\text { management of } \\
\text { diabetes in the } \\
\text { Eastern Cape }\end{array}$ & $\begin{array}{l}\text { Eastern Cape } \\
\text { Province, South } \\
\text { Africa }\end{array}$ & 45 & $\begin{array}{l}\text { 1) The identification of the active } \\
\text { compounds. } \\
\text { 2) Emphasis on neglected botanical } \\
\text { families for further studies. } \\
\text { 3) Mechanism of action studies and } \\
\text { comparison with existing conventional } \\
\text { drugs. }\end{array}$ & Odeyemi and Bradley, 2018 \\
\hline $\begin{array}{l}\text { Hypoglycaemic and } \\
\text { anti-diabetic } \\
\text { activity }\end{array}$ & Africa & 16 & $\begin{array}{l}\text { 1) Identify phytochemical constituents } \\
\text { linked to hypoglycaemic and anti- } \\
\text { diabetic activity. } \\
\text { 2) Conduct clinical trials. } \\
\text { 3) Investigate combinations with } \\
\text { synthetic drugs. }\end{array}$ & Oguntibeju, 2019 \\
\hline
\end{tabular}




\begin{tabular}{|c|c|c|c|c|}
\hline Subject matter & $\begin{array}{l}\text { Geographical } \\
\text { focus }\end{array}$ & $\begin{array}{l}\text { Number of } \\
\text { plant species } \\
\text { covered }\end{array}$ & Recommendations & Authors \\
\hline & & & $\begin{array}{l}\text { 4) Monitor and determine long-term } \\
\text { effects of medicinal plants. } \\
\text { 5) Investigate inter and intra-species } \\
\text { variation of secondary metabolites. } \\
\text { 6) Formulation studies. } \\
\text { 7) Develop acceptable approach of } \\
\text { fortifying local foods with herbal } \\
\text { products that have displayed significant } \\
\text { hypoglycaemic and anti-diabetic } \\
\text { activities. }\end{array}$ & \\
\hline $\begin{array}{l}\text { Diabetes mellitus } \\
\text { and antidiabetic } \\
\text { plants }\end{array}$ & \multicolumn{2}{|c|}{$\begin{array}{l}\text { None, but general overview of } \\
\text { global perspective }\end{array}$} & $\begin{array}{l}\text { 1) More emphasis on medicinal plants to } \\
\text { manage diabetes. }\end{array}$ & Chinsembu, 2019 \\
\hline
\end{tabular}




\begin{tabular}{|c|c|c|c|c|}
\hline Subject matter & $\begin{array}{l}\text { Geographical } \\
\text { focus }\end{array}$ & $\begin{array}{l}\text { Number of } \\
\text { plant species } \\
\text { covered }\end{array}$ & Recommendations & Authors \\
\hline $\begin{array}{l}\text { Medicinal plants } \\
\text { with concomitant } \\
\text { anti-diabetic effects } \\
\text { against diabetes }\end{array}$ & $\begin{array}{l}\text { Global } \\
\text { perspective }\end{array}$ & 64 & $\begin{array}{l}\text { 1) Need for dual acting anti-diabetic and } \\
\text { anti-hypertensive agents. } \\
\text { 2) Methodologically-balanced analyses } \\
\text { conducted on in vivo investigations. } \\
\text { 3) Toxicity and safety profile of the } \\
\text { majority of the medicinal plants. }\end{array}$ & Chukwuma et al., 2019 \\
\hline $\begin{array}{l}\text { Medicinal herbs, } \\
\text { spices, and food } \\
\text { plants for diabetes } \\
\text { management }\end{array}$ & $\begin{array}{l}\text { Global } \\
\text { perspective }\end{array}$ & 94 & $\begin{array}{l}\text { 1) Taxonomic classification should be } \\
\text { strictly adhered to. } \\
\text { 2) Ethnomedicinal uses more vigorously } \\
\text { reported. } \\
\text { 3) Attention given to traditional modes } \\
\text { of preparation. }\end{array}$ & Seetaloo et al., 2019 \\
\hline
\end{tabular}




\begin{tabular}{|c|c|c|c|c|}
\hline Subject matter & $\begin{array}{l}\text { Geographical } \\
\text { focus }\end{array}$ & $\begin{array}{l}\text { Number of } \\
\text { plant species } \\
\text { covered }\end{array}$ & Recommendations & Authors \\
\hline & & & $\begin{array}{l}\text { 4) Interactions and toxicology should be } \\
\text { studied. } \\
\text { 5) Standard use of methodology. }\end{array}$ & \\
\hline $\begin{array}{l}\text { Traditional uses } \\
\text { with } \\
\text { pharmacological } \\
\text { and toxicity focus }\end{array}$ & Nigeria & $\begin{array}{l}115 \text { plant } \\
\text { species }\end{array}$ & $\begin{array}{l}\text { 1) Need for pharmacovigilance and } \\
\text { standardization. } \\
\text { 2) Clinical evidence. }\end{array}$ & $\begin{array}{l}\text { Ezuruike and Prieto, } 2020 \text { in } \\
\text { press }\end{array}$ \\
\hline
\end{tabular}




\subsection{Classes of diabetes}

Diabetes mellitus is classified into four broad categories based on causes and physiological and metabolic features:

- Type $1 \mathrm{DM}$ is also called juvenile-onset DM. It is characterised by a loss of insulin producing $\beta$-cells in the Islets of Langerhans of the pancreas and is auto-immune related (Shafrir, 1996; American Diabetes Association, 2010; Cock and Cheesman, 2019). Type 1 DM accounts for approximately $10 \%$ of the cases of DM in Western countries. This disease may begin in either children or adults.

- Type $2 \mathrm{DM}$ is the most common class of DM with an adult onset. Type $2 \mathrm{DM}$ is caused by the resistance of the body to the action of insulin and is believed to result from nonfunctional/decreased functional insulin receptors (American Diabetes Association, 2010). This class of DM is most frequently caused by lifestyle factors including obesity, lack of physical activity, poor diet and stress. Genetic factors may also be involved and a higher correlation with obesity has been noted for some ethnic groups.

- Gestational DM (GDM) has features that resemble both type 1 and type 2 DM, with both inadequate levels of insulin secretion and substantially decreased responsiveness. It occurs in up to $10 \%$ of pregnancies and the symptoms often disappear following delivery, although the symptoms remain in up to $10 \%$ of women with GDM (American Diabetes Association, 2010). Despite the transient nature of this disease, GDM may cause considerable damage to both the mother and foetus if not effectively treated.

- Type $3 \mathrm{DM}$ is a relatively new area of diabetic associated insulin deficiency, where cognitive functions decline. There has been some interlinked association between types 1 and 2 diabetes with a positive correlation to enhancing Alzheimer's disease (Kandimalla et al., 2017).

\subsection{Causes of diabetes mellitus}


Diabetes is caused by carbohydrate metabolism abnormalities which may be linked to low blood insulin levels or to target organ insensitivity to insulin (Maiti et al., 2004). The key function of insulin is to respond to the combined action of several hyperglycaemia-generating hormones and to maintain glucose levels at a normal level of less than $5.6 \mathrm{mmol} / \mathrm{L}$, particularly in response to food consumption (King, 2014). The increase in the number of people suffering from DM is linked in part to the ageing global population. It is also caused by calorie-rich diet consumption, obesity and a sedentary lifestyle which has resulted from changes that have occurred in the human environment, human behaviour and lifestyle due to globalisation (Zimmet et al., 2001; Oyedemi et al., 2009).

\subsection{Symptoms of diabetes mellitus}

High blood sugar levels can induce a variety of physiological symptoms. Due to loss of glucose, individuals with untreated DM frequently have sudden and substantial unintentional weight loss. Polyuria (increased urine volume), polydipsia (increased thirst), polyphagia (increased hunger), are all common symptoms (American Diabetes Association, 2010). The onset of symptoms is generally rapid in people with type $1 \mathrm{DM}$ and the symptoms are generally evident within weeks of the onset of the disease. The onset of symptoms is generally substantially slower in people with type $2 \mathrm{DM}$ and may be much more subtle.

Several other signs and symptoms may also manifest in DM, although they are not specific to the disease. These include fatigue, headache, blurred vision, dry, itchy skin and the slow healing of cuts and abrasions. Prolonged hyperglycaemia can also result in high blood pressure. This in turn can cause glucose absorption into the lens in the eye, thereby changing its shape and affecting visual acuity. Long-term hyperglycaemia can cause more severe damage, resulting in vision loss (diabetic retinopathy). Skin rashes (diabetic dermadrones) are also frequently encountered. 


\subsection{Current treatment options for diabetes mellitus and role of alternate therapies}

Several methods are used to treat diabetes. For type $1 \mathrm{DM}$, treatment with exogenous insulin is usually effective. For type $2 \mathrm{DM}$, lifestyle modifications including a change of diet and increased exercise are often effective. Pharmacotherapy with drugs such as metformin and selective low-affinity sodium glucose cotransporter (SGLT2) inhibitors are also often effective (Mudaliar and Henry, 2001; Klein et al., 2004; Chao and Henry, 2010). Metformin functions by improving glucose tolerance, lowering both basal and postprandial plasma glucose levels. It decreases the gluconeogenesis production in the liver, lowers absorption of glucose in the intestine and leads to improvement of insulin sensitivity through the increase of peripheral glucose uptake and consumption (Bailey and Turner, 1996). The SGLT2 inhibitors work by inducing glucosuria, resulting in increased excretion of glucose in the urine. When these drugs are co-administered over a longer period, a lower level of glycated haemoglobin is observed (Abdul-Ghani et al., 2012).

Another method used to treat, and control DM is with medicinal plants and traditional medicines. Consultation with traditional and folk medicine healers for the treatment of DM is particularly prevalent among rural patients (Semenya et al., 2012). Modern antidiabetic drug therapy is costly and is not affordable to the people in the low-income groups living in the rural areas such as the Eastern Cape and Limpopo provinces of South Africa (Erasto et al., 2005). Furthermore, inhabitants of these regions may be long distances from medical clinics and allopathic medicines are not always available. Thus, there is a need for cheaper, more readily available therapeutic alternatives. Allopathic drug therapy for DM may also induce a wide range of side effects including hypoglycaemia, weight gain, gastrointestinal discomfort, nausea, liver and heart failure, as well as diarrhoea (Stack, 2008). Conversely, if not effectively 
treated, the long-term effects of hyperglycaemia may lead to damage, dysfunction and failure of various organs including the eyes, kidneys, nerves, heart and blood vessels and can result in renal failure and amputation (American Diabetes Association, 2010). An examination of the hypoglycaemic effects of traditional medicines may highlight new drug leads with enhanced efficacy and fewer or less severe side effects.

One aspect only recently considered is the role of the gut microflora in the control of DM. Studies have shown that an imbalance in the distribution of microbial communities in the gut can result in a malfunction of bacterial metabolic activity resulting in obesity, insulin resistance and the onset of type 2 diabetes. Prebiotics, probiotics, and feacal microbiota transplantation have been proposed has therapeutic options to correct microbial balance and therefore indirectly control DM (Leylabadlo et al., 2020). From an African perspective (Nigerian context), it has been shown that the gut microbiota of elderly people living with Type 2 diabetes is not consistent with a healthy gut biome, and gut microbiota modification are warranted (Afolayan et al., 2020).

\subsection{The use of medicinal plants in diabetes treatment}

Prior to the advancements of modern medicine over the last century, plant-based therapies were used for the treatment and maintenance of DM. Their usage dates back to the earliest written records, and likely much earlier. Indeed, the Egyptian Papyrus Ebers (circa $1550 \mathrm{BC}$ ) records the usage of various grains in the treatment of DM (Bailey and Day, 1989), and numerous other texts have described the use of herbs, spices and other plant materials for the same purposes (Ryan et al., 2001; Upendra Rao et al., 2010). With the more recent availability of insulin and oral antidiabetic agents (e.g. sulfonylureas, biguanides, $\alpha$ glucosidease inhibitors, glinides), the use of herbal medicines to treat DM has almost disappeared in Western medicine systems. However, traditional use remains common in 
developing countries, as well as in rural and isolated areas of more developed countries. Even in Western countries that use allopathic therapies almost exclusively, there has been a recent revival in the use of herbal medicines and some studies have reported that up to a third of people with DM in those countries take herbal medicines, usually as an adjunct to allopathic therapies (Ryan et al, 2001).

It has been estimated that more than 1000 plant remedies are used globally for the treatment and maintenance of DM (Marles and Farnsworth, 1995). However to date, relatively few of these have had their usage validated by rigorous scientific evaluation and fewer have had their mechanisms of action determined. Of these, the therapeutic properties and usage of specific species have been reviewed elsewhere (El Haouari et al, 2019; Yusuf et al, 2012; Baskaran et al 1990). Many of these species are widely distributed and cultivated and have been naturalised globally. For example, Allium sativum L (garlic; origin unknown although the high diversity in central Asia indicates China may be the origin), Annona squamosa L. (custard apple, sweetsop; origin, tropical region of the Americas). Berberis vulgaris L. (sugarbeet, beetroot, chard, spinach beet; origin, Southeast Europe to Western Asia), Lantana camara L. (lantana, big-sage; origin, American tropics) and Momordica charantia L. (bitter melon; origin, India) are distributed globally and their therapeutic usage is often better known in areas where they have been naturalised than in their area of origin. Notably, several of these species are grown in South Africa and are used in South African traditional medicine systems, including for the treatment of DM. A study group on the management of diabetes among Zulu traditional health practitioners revealed that the majority of treatments involved herbal mixtures referred to as Amakhambi. The exact composition is unknown, but plant species dominant to the mixture include Aloe vera (L.) Burm.f. and A. sativum (Frimpong and Nlooto, 2019)

Many of these species have been relatively well-studied (as reviewed in Upendra Rao et al., 2010) and the major active components have been identified. All have been shown to 
have hypoglycaemic effects. However, with very few exceptions, the efficacy of these plants (and purified compounds) have been investigated using in vivo model systems. Whilst these studies have verified the therapeutic efficacy of these species, they have done little to elucidate the mechanism of action and substantial more work is required in this field. Furthermore, whilst many other species have been recorded in the traditional medicine literature as therapies for diabetes, they are often yet to be evaluated. Future studies to verify the efficacy of these species, and to determine how they decrease blood glucose levels are required.

Interestingly, even in developed countries where allopathic medicine dominates, plant derived compounds are widely used to treat DM. Several biguanide drugs including metformin, phenormin and buformin were initially isolated from Galega officinalis L. (commonly known as French lilac, goat's rue). All of these drugs are noted to specifically lower blood glucose levels. Whilst phenormin and buformin were withdrawn from clinical usage in the maintenance of DM in the 1970s due to toxicity concerns (Tonascia and Meinert, 1986), metformin remains a first-line medication for the treatment of type 2 DM (Maruthur et al., 2016). These drugs function via a variety of mechanisms that increase insulin sensitivity, without affecting insulin production and/or secretion. Instead, their therapeutic effects are due to a direct stimulation of glucose uptake and an inhibition of gluconeogenesis, both of which decrease blood glucose levels (Song, 2016). Two recent reviews (Apaya et al., 2020; Rasouli et al., 2020), provide an extensive overview of plant compounds together with emerging trends toward mechanistic studies and clinical perspectives.

\section{An overview of diabetes mellitus in South Africa}


It was estimated that in 2009, approximately two million South Africans over the age of 30 (9\% of that age group nationally) had diabetes (Bertram et al., 2013). This represents an almost doubling in prevalence from nine years earlier, when it was reported that $5.5 \%$ of South Africans above the age of 30 had the disease (Bertram et al., 2013). Of concern, the incidence is expected to continue to rise at similar rates in coming years. In part, the South African situation relates to recent economic successes and the upward mobility of the poorer classes into middle- and higher-income brackets. These increases in wealth bring with them associated lifestyle changes including higher food intake and the consumption of an increasing 'Westernised' diet high in fats, coupled with lower levels of activity (Kengne et al., 2013; Peer et al., 2014; Pheiffer et al., 2017). Similarly, greater urbanisation due to the availability of employment opportunities has also accelerated these social and nutritional changes (Steyn et al., 1997; Vorster et al., 2005). These factors are directly related to obesity, which in turn is related to several morbidities, including DM. Indeed, it was estimated in 2000 that $87 \%$ of DM cases directly correlated with excess body weight (Joubert et al., 2007). This is particularly concerning as a recent survey estimated that $38 \%$ of men and $69 \%$ of women in South Africa are overweight or obese (Ng et al., 2014).

Socio-economic status and the level of education are perhaps the factors most correlated with the incidence of DM in South Africa. A recent epidemiological study reported that economic status was the most important factor in the development of DM (Soetedjo et al., 2018). Indeed, the highest prevalence of DM was in South Africans from the richest socioeconomic group ( $42 \%$ of all the surveyed South Africans with DM), with individuals in the upper middle (33.3\%) and middle-income brackets (14.8\%) also having high rates of DM. In contrast, only $9.8 \%$ of South Africans with DM were poor. It is evident that the lifestyle changes associated with increased income are largely responsible for the prevalence of DM in South Africa. Educational level was also a major contributing factor to the development of 
DM. The same study reported that $74.4 \%$ of the South Africans with DM had no formal education, or had only a primary school level of education, whilst a further $17.1 \%$ had secondary education. In comparison, $6.1 \%$ had completed high school education and only $1 \%$ had university education. It is likely that an understanding of DM and the lifestyle factors from formal education significantly decreases the likelihood that South Africans to develop DM.

A correlation between ethnicity and the prevalence of DM is also evident. A higher than average incidence of morbidity and mortality from DM has been reported in black South African populations compared with other South African ethnic groups (Erasto et al., 2005). As DM correlates with economic transition, increased urbanisation and the consumption of high fat, high energy foods, it is likely that the prevalence of DM amongst black South Africans will continue to rise more rapidly than the South African average as their economic conditions continue to improve. A recent survey also highlighted several other risk factors in South Africans with DM and reported that an aging population also contributes to the increased incidence of DM, with a median age of 54 years estimated for South Africans with DM (Soetedjo et al., 2018). With better medical access becoming available to many South Africans, the life expectancy has increased, resulting in an aging population. As DM is most prevalent in the older age groups, it is possible that this increased life expectancy is at least partly responsible for the current South African situation. That study also identified several other risk factors. There was a substantially higher prevalence of women with DM. Indeed, an estimated $65 \%$ South Africans with DM are female. This closely correlates with recent estimates of the rates of overweight and obesity in South Africans (38\% of men, $69 \%$ of women; $\mathrm{Ng}$ et al, 2013), further confirming the importance of obesity as a risk factor for DM.

Furthermore, gestational diabetes mellitus (GDM) also occurs at greater prevalence in black South Africans (also in Asian South Africans), than in other ethnic groupings (Macaulay et al., 2018). Indeed, that study reported that $9.1 \%$ of pregnant black South African women 
tested had GDM, a risk factor for the development of type 2 DM in both the mother and the unborn child (Dabelea and Crume, 2011). The higher prevalence of GDM in black South African populations results in further health complications and morbidities, as well as decreased longevity. Furthermore, the increasing prevalence of DM places further burden on the South African healthcare system.

\section{Materials and methods}

Information presented in this review was sourced from a variety of southern African related ethnobotanical books (Watt and Breyer-Brandwijk, 1962; Hutchings et al., 1996; Von Koenen, 1996; Van Wyk et al., 2009) and various ethnobotanical reviews (Erasto et al., 2005; Thring and Wietz, 2006; Afolayan and Mbaebie, 2010; Semenya et al., 2012; Mahwasane et al., 2013; Chauke et al., 2015; Davids et al., 2016; Moteetee et al., 2019; Hulley and Van Wyk, 2019). Original scientific research papers were identified and selected using the GoogleScholar, PubMed, Scopus and Science-Direct electronic databases. The filters used included the following terms, searched either alone or in combinations: "South African", "medicinal plant", "traditional medicine", "ethnobotany", "diabetes" and "blood sugar". The study was non-biased, without emphasis on endemic species, date of publishing nor with any taxonomic preference. One hundred and thirty-seven southern African plant species were identified as traditional therapies for the treatment of DM. The vast majority of these are native South African plants, although a few introduced species that are widely cultivated and are now considered an integral part of the pharmacopeia of at least one ethnic group were also included. A thorough literature review was then undertaken on each of the identified plant species to identify any research studies examining the identified species for DM related therapeutic 
activities. While the authors are cognisant that some literature sources may be of higher credibility than others, the goal here was to provide an unbiased and comprehensive approach.

Criteria for inclusion in this study included ethnomedicine, human usage, medicinal plants of South African and other key words related to DM and treatment. To be included in this study, each plant had to have been recorded as being use traditionally in South Africa to treat DM, or its symptoms. Plants that were used within land locked countries within South Africa such as Lesotho were included, but those that were further scattered into mid-Africa or further afield were excluded. Also excluded were terms such as "diabetic wounds" or "obesity" or other health conditions associated with diabetes complications. Scientific evidence to support traditional use was not included in the initial ethnobotanical literature search but was included in follow-up searches to determine if the traditional usage has been validated. Our study aimed to update these earlier reviews and to take a broader approach to the ethnobotanical usage of South African plants in the treatment of DM, with the hopes of highlighting plant species for future research in this area. All taxonomic revisions were considered by checking with the database "The Plant List. A Working List of All Plant Species" (http://www.theplantlist.org/tpl1.1/search?).

\section{South African medicinal plants traditionally used to treat diabetes mellitus}

Traditional medicines are often used to target disease symptoms and therefore it may often be difficult to discern between treatments for diseases with similar symptoms. For example, ethnobotanical records may list a traditional medicine as useful in the treatment of increased urine output, which may be a symptom of numerous diseases including DM, benign prostatic hyperplasia, or several urinary tract infections (UTIs). Indeed, in other parts of the world, U. dioica is indicated for inflammation and prostatic hyperplasia (Upton, 2013), as well 
as for diabetes (El Haouari and Rosado, 2019). Whether the usage of $U$. dioacia in traditional South African medicine is due to symptomatic relief, or if its use is targeted more specifically at DM is unclear. Similarly, increased thirst and hunger may also be symptoms of numerous other diseases, such as intestinal worms and helminths (Cock et al., 2018a). Only plant species that were reported to be treatments for DM are included here. Where the basis for the therapeutic usage was ambiguous, the plant species has been excluded from this review.

Reference to a total of 137 plants from 36 families that are used in the management of blood sugar were found in literature (Table 2). Some plant species such as Aloe ferox Mill., Artemisia afra Jacq. ex Wild., Dicoma anomala Sond. subsp. anomala, Momordica balsamina L, Opuntia ficus-indica L., Pentanisia prunelloides (Klotzch ex. Edd \& Zeyh.) Walp., Lessertia frutescens subsp. frutescens (L.) Goldblatt \& J.C. Manning (previously referred to as Sutherlandia frutescens) and Eriocephalus punctulatus DC have been cited by various sources providing validity to their traditional use to treat DM, while others $(64 \%)$ have been only mentioned once. The South African plant species that are commonly used in the treatment of diabetes come from a wide range of families (Figure 1a). The Asteraceae family were consistently the most highly represented family for the treatment and maintenance of DM. Indeed, the usage of 26 species from the Asteraceae family was recorded as treatments for DM (Table 2). This is not unexpected, as a recent family-level floristic study lists Asteraceae as one of the top families represented in African traditional medicine (Van Wyk, 2020)

Apocynaceae (10 species), Lamiaceae (nine species) and Xanthorrhoeaceae (nine species) were also well represented. This is consistent with similar reports examining the antiDM properties of plants in other parts of Africa (Abo et al., 2008; Keter and Mutiso, 2012).

Figure $1 \mathrm{~b}$ shows the usage distribution of the different plant parts for the treatment of blood sugar. The most common plant part used in the treatment of diabetes is the leaves $(39 \%)$ (Fig 1b) as the leaves are believed to be the most potent part of many plants (Davids et al., 
2016). The leaves of multiple Aloe species including A. arborescens Mill., A. ferox Mill., A. greatheadii (Schönland) Glen \& D.S.Hardy, A. maculata All., A. marlothii A. Berger, A. microstigma Salm-Dyck and $A$. vera were listed in South African ethnobotanical records as the sole (or main) plant part used to treat DM. Many other studies have documented the use of leaves for medicinal purposes (Nain et al., 2012; Yassa and Tohamy, 2014; Baldissera et al., 2016; Cock and Cheesman, 2018b). Interestingly, for several of these species, the roots, bark, twigs or whole plant were also sometimes used. It is unclear from the published records whether these differences relate to the practices of different ethnic groups, the availability of the plant part, or if they were targeted at different symptoms of DM.

Other parts of the plant used in the treatment of diabetes include roots, bulbs, bark, stems and the whole plant. The roots were particularly widely used, being the sole or main plant part used for approximately $21 \%$ of the recorded species. It is believed that the healing power of the plant is often stored in the roots, in the same way that it is stored in the leaves. The roots were the third most frequently used plant part (Fig.1b, Table 2). Fruits and seeds are rarely used because they are only available during certain seasons of the year. Similarly, bark is not always available for wild harvesting as it may often be stripped off by African macrofauna. Furthermore, bark should only be used sparingly as its removal damages the plant and may kill the more sensitive species. Notably, many herbaceous species are used for the treatment of diabetes (Semenya et al., 2012). The use of these parts of the plant have implications for sustainable harvesting (Davids et al., 2016). Many medicinal plants are endangered and some are close to extinction (Street et al., 2008) and therefore the usage of plant parts where harvesting does not cause extensive damage is encouraged.

For some of the plants (29\%) used to treat DM, we were unable to determine which plant part is traditionally used as it has not been specified in the available literature. It is often difficult to identify the most active part of plant because of the difference in preparation and in 
the doses and duration that the medicine is used to be effective. Furthermore, variation in methods used to determine the antidiabetic parameters also makes comparisons difficult (Mohammed et al., 2014). Further research is required to determine the part(s) of these species that is best suited for the treatment of DM. 
(A)

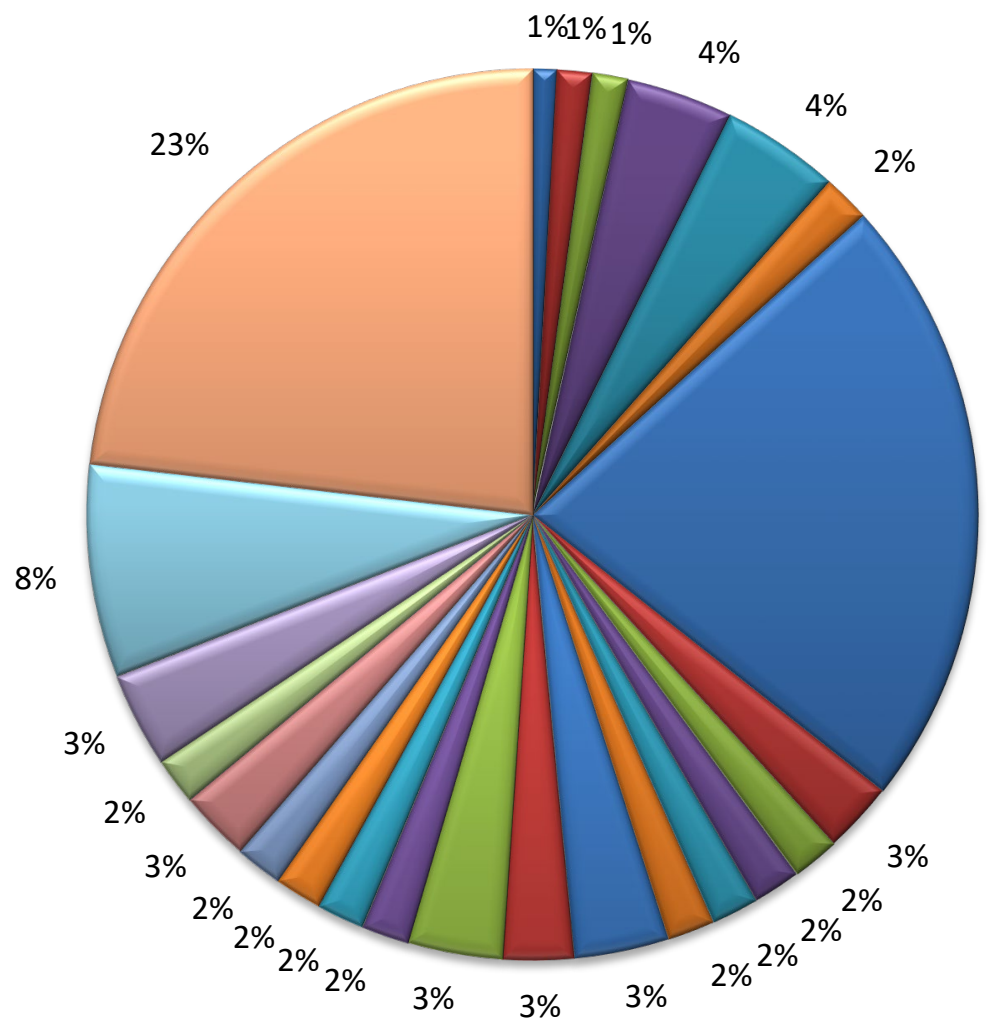

- Amaryllidaceae

- Apiaceae

- Asteraceae

ㄴamiaceae

- Apocynaceae

$\square$ Amaranthaceae

口 Asteraceae

$22 \%$

Ebenaceae

$\square$ Euphorbiaceae

口 Anacardiaceae

$\square$ Cactaceae

$\square$ Crassulaceae

- Cucurbitaceae

- Leguminosae 
(B)

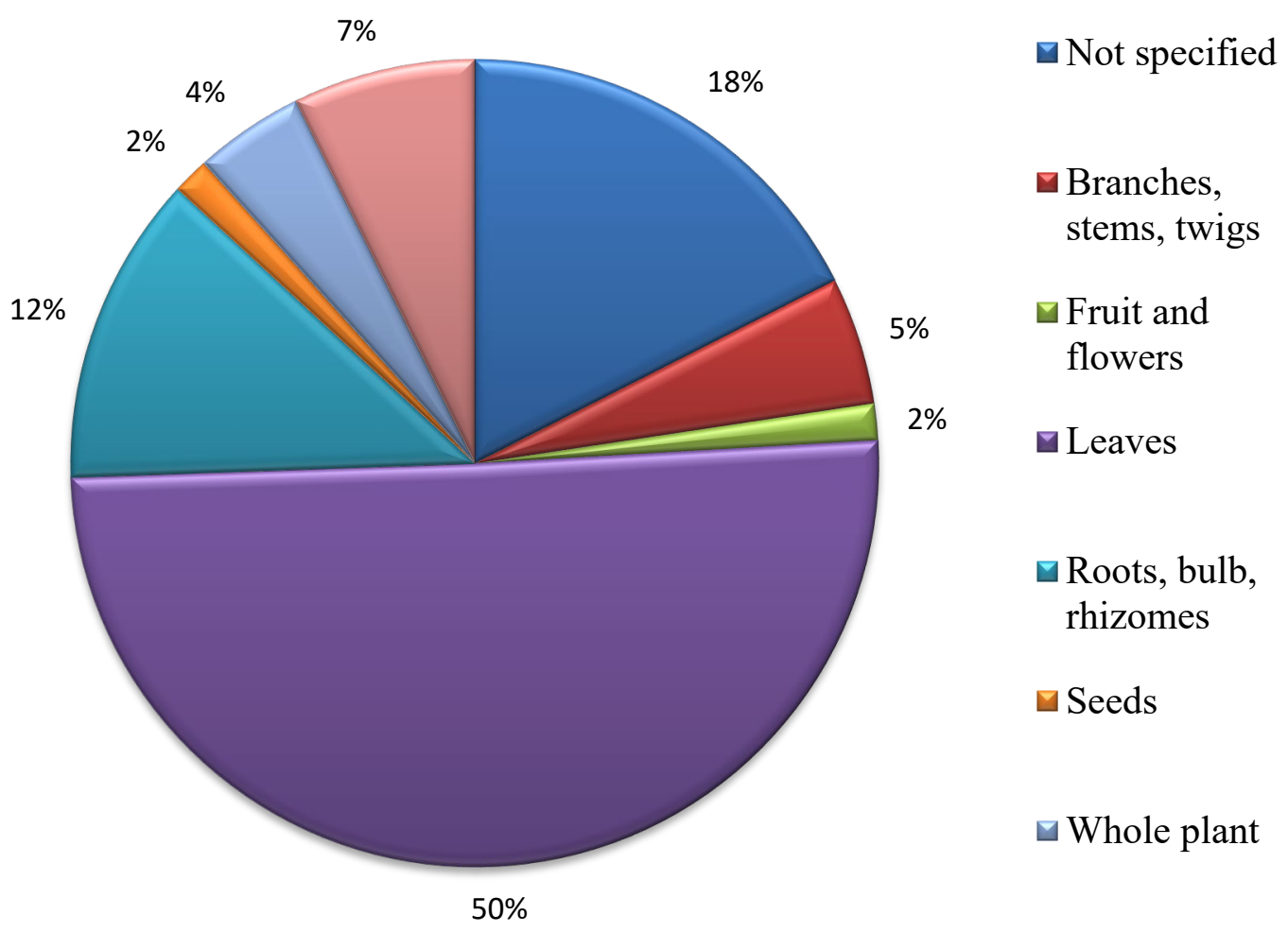

Fig 1. The plant (A) families and (B) parts used traditionally in South Africa to reduce blood glucose concentrations in the treatment of DM. 


\section{Table 2}

South African plant species used for the treatment of blood sugar.

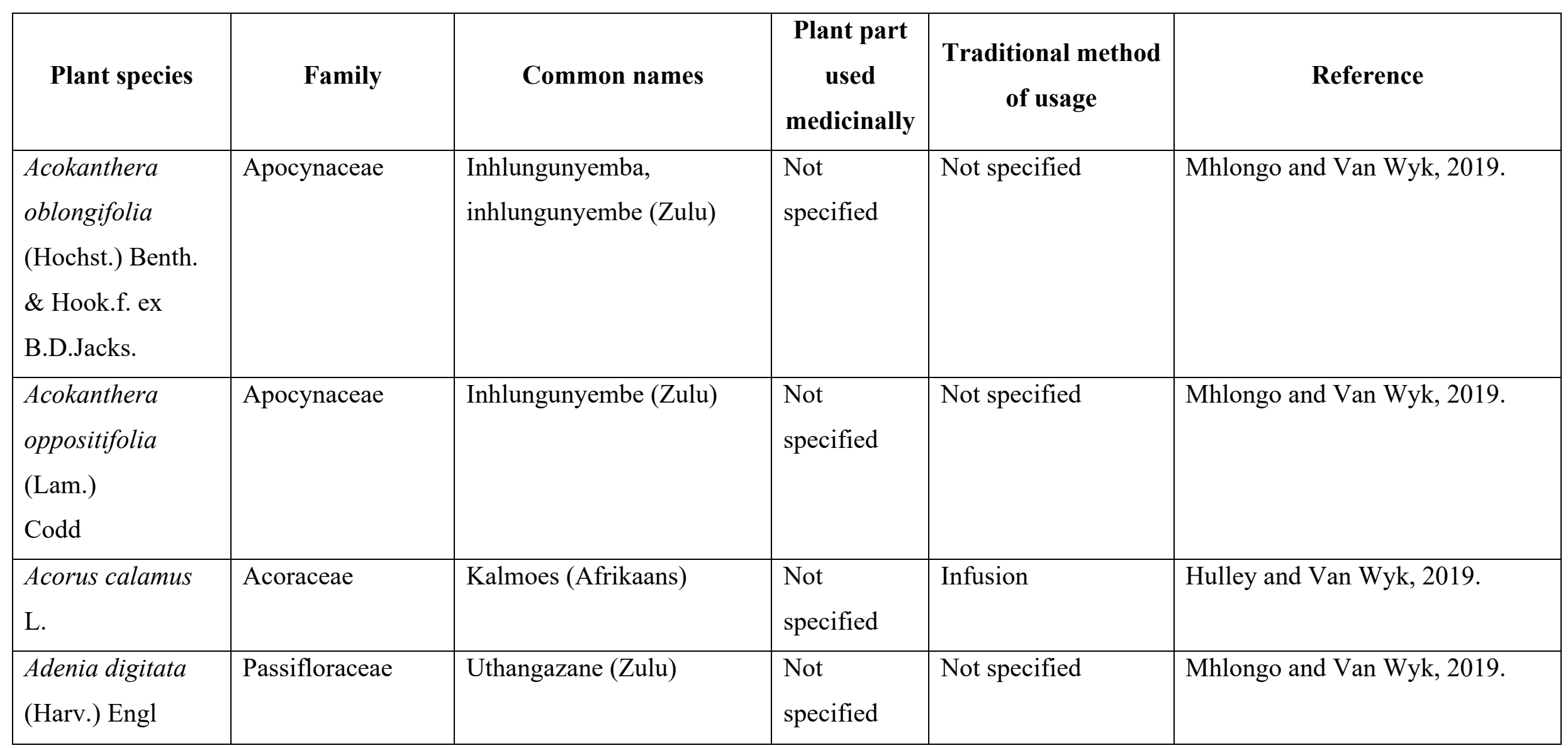




\begin{tabular}{|c|c|c|c|c|c|}
\hline Plant species & Family & Common names & $\begin{array}{c}\text { Plant part } \\
\text { used } \\
\text { medicinally }\end{array}$ & $\begin{array}{c}\text { Traditional method } \\
\text { of usage }\end{array}$ & Reference \\
\hline Aloe ferox Mill. & Xanthorrhoeaceae & $\begin{array}{l}\text { Cape aloe (English), } \\
\text { bitteraalwyn, winkelaalwyn } \\
\text { (Afrikaans), iKhala } \\
\text { (Xhosa), iNhlaba (Zulu) }\end{array}$ & $\begin{array}{l}\text { Leaves, } \\
\text { Roots }\end{array}$ & $\begin{array}{l}\text { Decoctions are } \\
\text { ingested to treat } \\
\text { diabetes. }\end{array}$ & $\begin{array}{l}\text { Moffett, 2010; Moteetee and Van } \\
\text { Wyk, 2011; Amoo et al., 2014; } \\
\text { Nortje and Van Wyk, 2015; Cock, } \\
\text { 2015a; Davids et al., 2016; Hulley } \\
\text { and Van Wyk, 2019; Moteetee et } \\
\text { al., 2019. }\end{array}$ \\
\hline $\begin{array}{l}\text { Aloe greatheadii } \\
\text { var. davyana } \\
\text { (Schönland) Glen } \\
\text { \& D.S.Hardy }\end{array}$ & Xanthorrhoeaceae & $\begin{array}{l}\text { Spotted aloe (English), } \\
\text { Transvaalaalwyn, } \\
\text { grasaalwyn (Afrikaans) }\end{array}$ & Leaves & $\begin{array}{l}\text { Decoctions are used } \\
\text { to treat diabetes. }\end{array}$ & Amoo et al., 2014; Cock, 2015a. \\
\hline
\end{tabular}




\begin{tabular}{|c|c|c|c|c|c|}
\hline Plant species & Family & Common names & $\begin{array}{c}\text { Plant part } \\
\text { used } \\
\text { medicinally }\end{array}$ & $\begin{array}{c}\text { Traditional method } \\
\text { of usage }\end{array}$ & Reference \\
\hline $\begin{array}{l}\text { Aloe marlothii A. } \\
\text { Berger }\end{array}$ & Xanthorrhoeaceae & $\begin{array}{l}\text { Sekgopha, kgopha ya go } \\
\text { ema (Sepedi), bindamutshe } \\
\text { (Tshivenda), mhangani } \\
\text { (Tsonga) }\end{array}$ & $\begin{array}{l}\text { Leaves and } \\
\text { roots }\end{array}$ & $\begin{array}{l}\text { The thorns are } \\
\text { removed from the } \\
\text { leaves and the leaves } \\
\text { are mixed with } \\
\text { water and } \\
\text { consumed. }\end{array}$ & Mogale et al., 2019. \\
\hline $\begin{array}{l}\text { Aloe vera }(\mathrm{L} .) \\
\text { Burm.f. }\end{array}$ & Xanthorrhoeaceae & $\begin{array}{l}\text { Burn aloe, True aloe, } \\
\text { Indian aloe, Barbados aloe } \\
\text { (English) }\end{array}$ & Leaves, gel & $\begin{array}{l}\text { Decoctions are } \\
\text { ingested to treat } \\
\text { diabetes. }\end{array}$ & $\begin{array}{l}\text { Balogun et al., 2016; Cock, } \\
\text { 2015a. }\end{array}$ \\
\hline $\begin{array}{l}\text { Anacardium } \\
\text { occidentale L. }\end{array}$ & Anacardiaceae & $\begin{array}{l}\text { Cashew tree, cashew, } \\
\text { cashew nut, cashew nut }\end{array}$ & Bark & $\begin{array}{l}\text { Oral administration } \\
\text { of a tincture. }\end{array}$ & $\begin{array}{l}\text { Watt and Breyer-Brandwijk, } \\
1962 .\end{array}$ \\
\hline
\end{tabular}




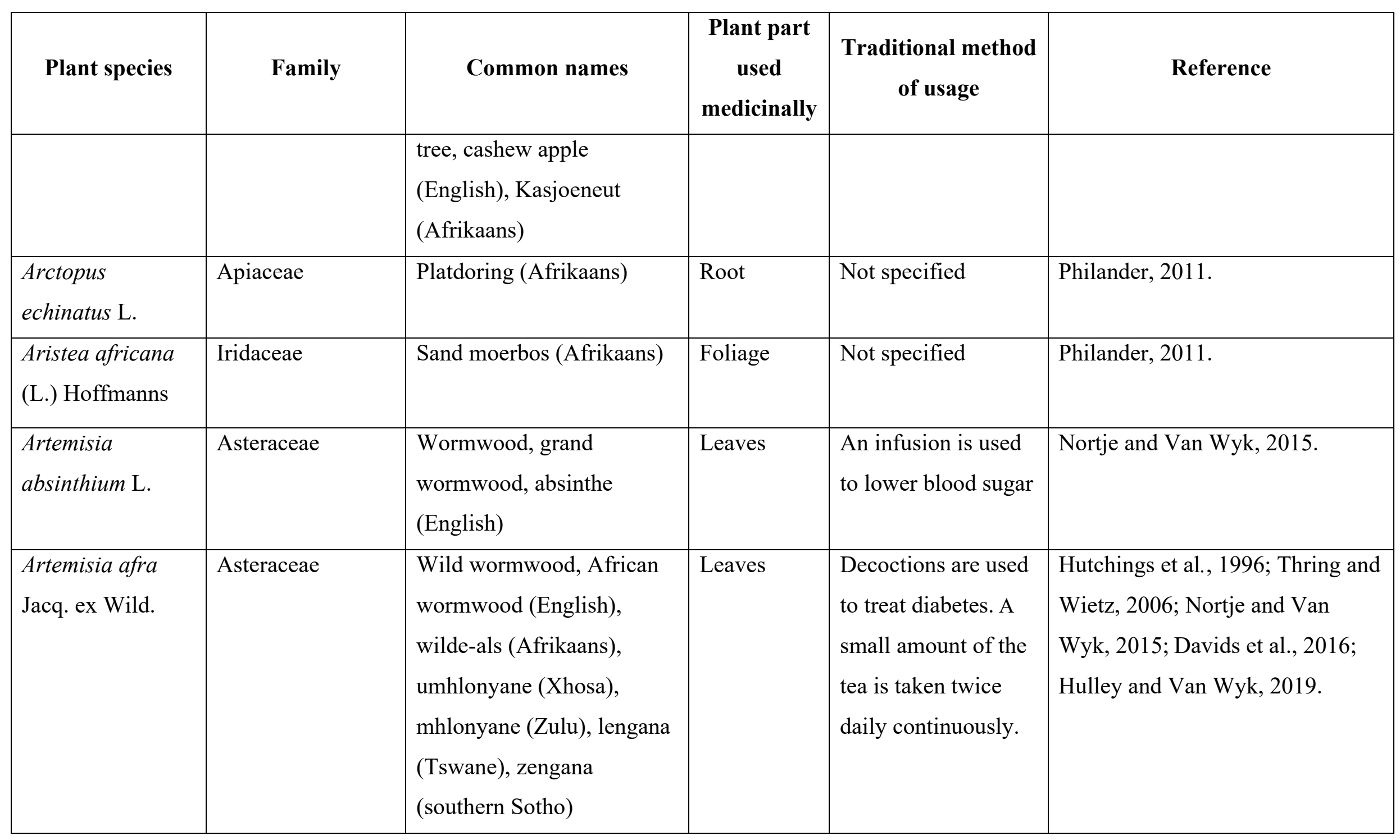




\begin{tabular}{|c|c|c|c|c|c|}
\hline Plant species & Family & Common names & $\begin{array}{c}\text { Plant part } \\
\text { used } \\
\text { medicinally }\end{array}$ & $\begin{array}{c}\text { Traditional method } \\
\text { of usage }\end{array}$ & Reference \\
\hline $\begin{array}{l}\text { Asclepias } \\
\text { fruticosa } \mathrm{L} \text {. }\end{array}$ & Apocynaceae & $\begin{array}{l}\text { African milkweed, wild } \\
\text { cotton, fire sticks (English), } \\
\text { wilde kapok, melkbos, } \\
\text { falsche bauwolle } \\
\text { (Afrikaans), ulusinga, } \\
\text { lwesalukazi (Zulu), } \\
\text { lebeyana, modimolo } \\
\text { (Sotho) }\end{array}$ & Dried roots & $\begin{array}{l}\text { An infusion } \\
\text { prepared from the } \\
\text { dried roots is } \\
\text { consumed. }\end{array}$ & Von Koenen, 2001. \\
\hline $\begin{array}{l}\text { Brachylaena } \\
\text { discolor DC. }\end{array}$ & Asteraceae & $\begin{array}{l}\text { Coastal/Natal silverleaf, } \\
\text { silver oak (English), } \\
\text { bosvaalbos, kreukelboom, } \\
\text { kusvaalbos, vaalbos } \\
\text { (Afrikaans), iPhahla, } \\
\text { iphahla (Zulu), umPhahla }\end{array}$ & Leaves & $\begin{array}{l}\text { An infusion is used } \\
\text { to lower blood } \\
\text { sugar. }\end{array}$ & $\begin{array}{l}\text { Hutchings et al., 1996; Corrigan et } \\
\text { al., } 2010 \text {. }\end{array}$ \\
\hline
\end{tabular}




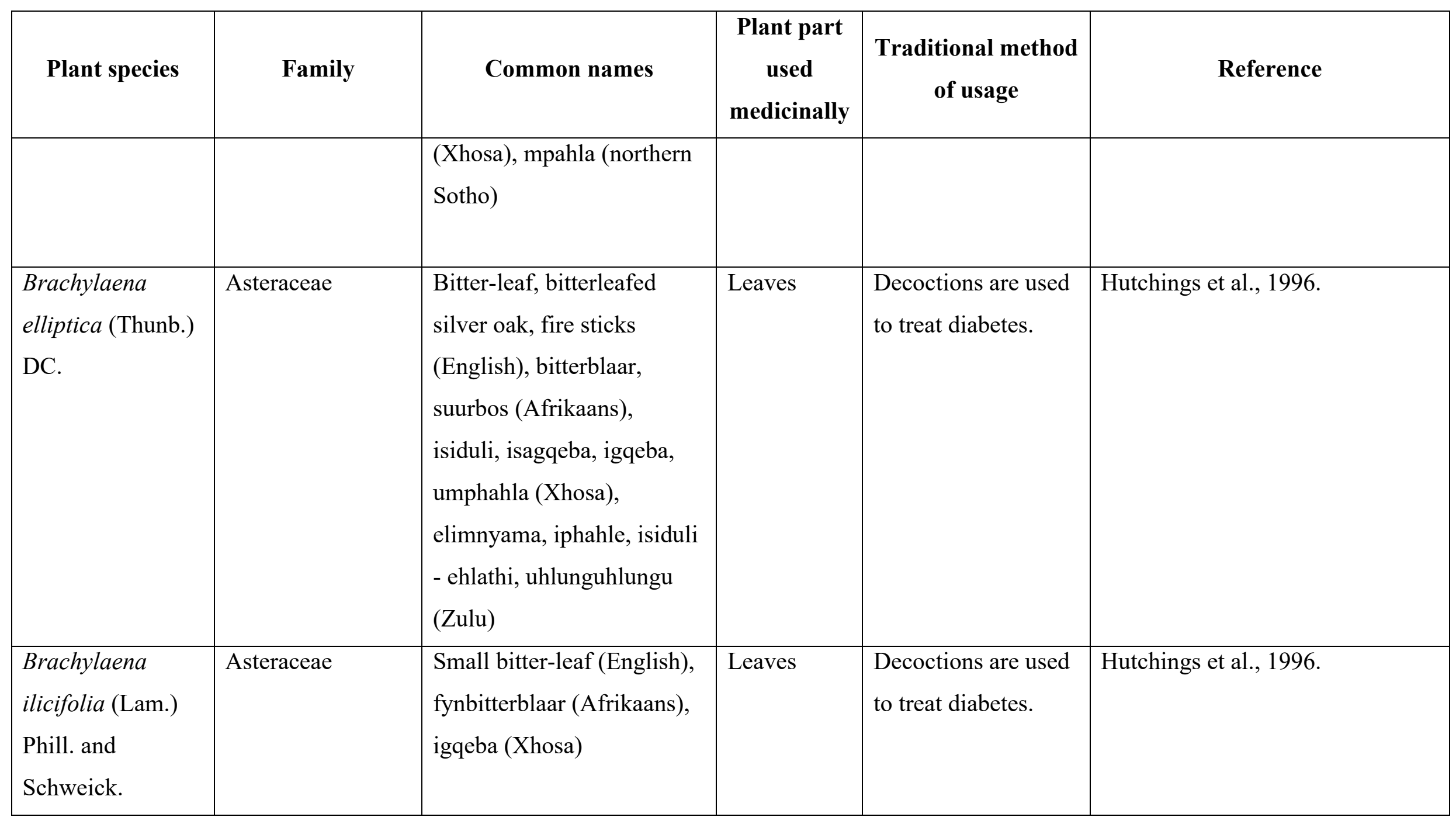




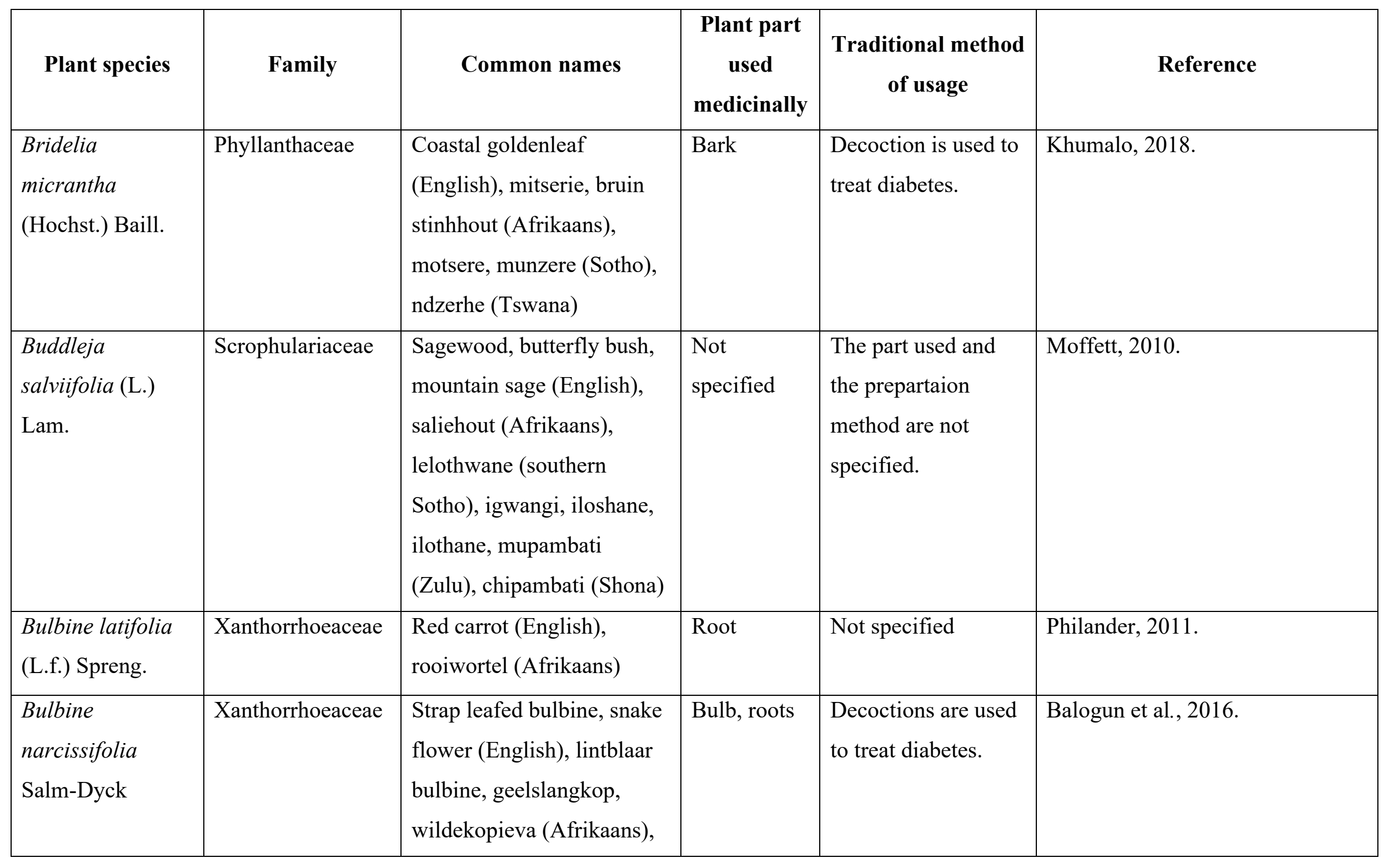




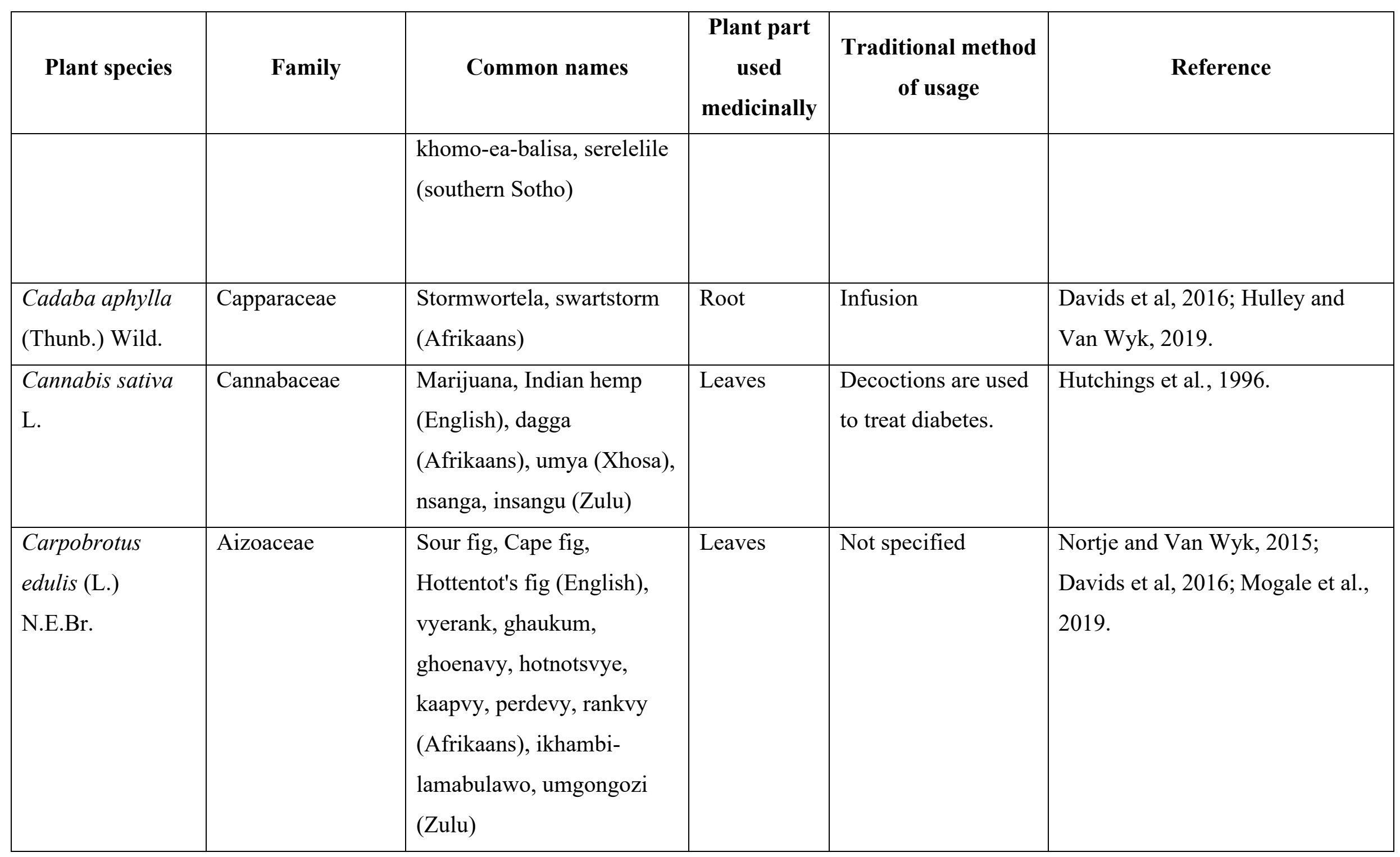




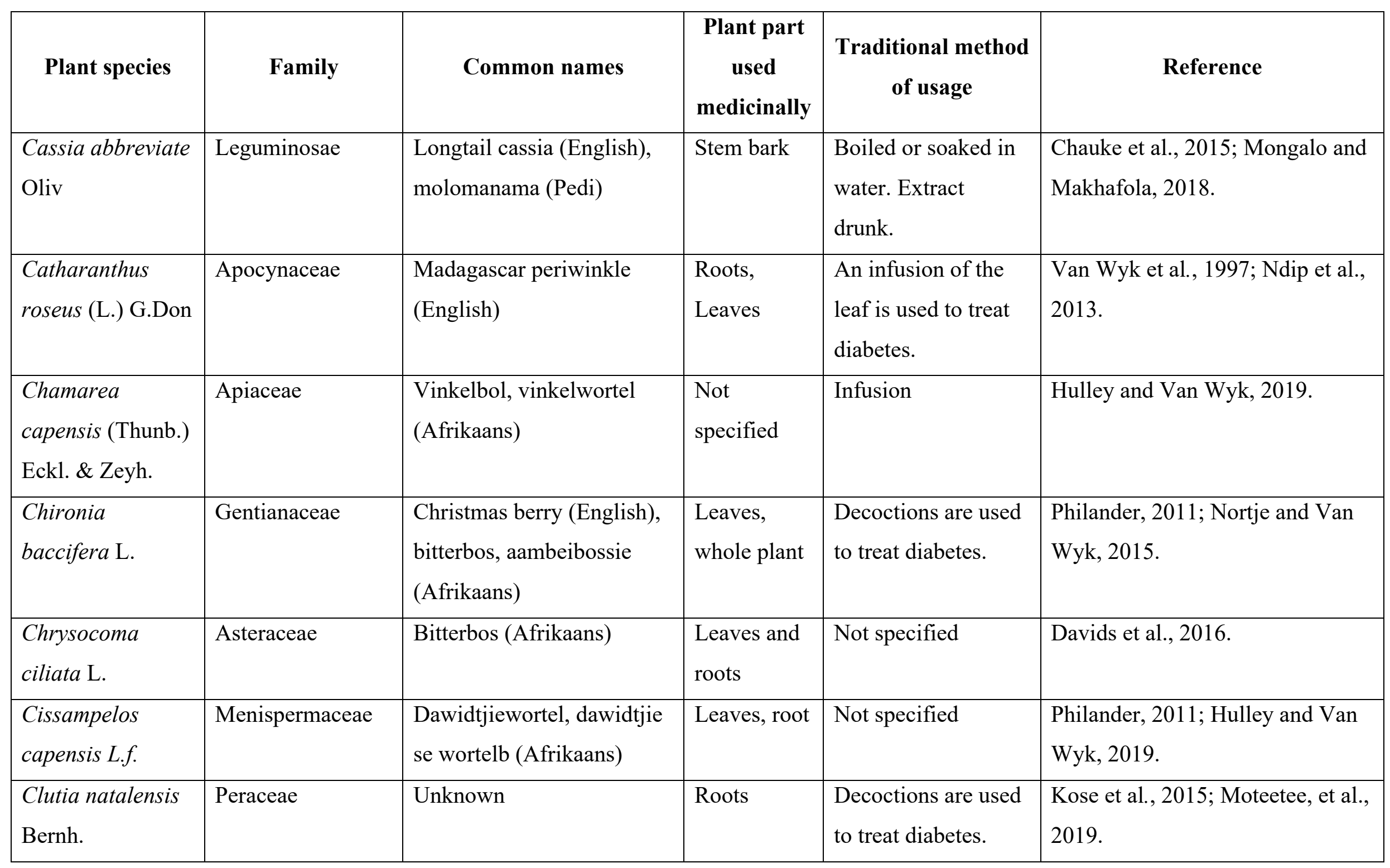




\begin{tabular}{|c|c|c|c|c|c|}
\hline Plant species & Family & Common names & $\begin{array}{c}\text { Plant part } \\
\text { used } \\
\text { medicinally }\end{array}$ & $\begin{array}{c}\text { Traditional method } \\
\text { of usage }\end{array}$ & Reference \\
\hline $\begin{array}{l}\text { Coleonema album } \\
\text { (Thinb.) Bartl. \& } \\
\text { H.L. Wendl. }\end{array}$ & Rutaceae & $\begin{array}{l}\text { Aasbossie (Afrikaans), } \\
\text { confetti bush (English) }\end{array}$ & Foliage & Not specified & Philander, 2011. \\
\hline $\begin{array}{l}\text { Commiphora } \\
\text { africana (A.Rich.) } \\
\text { Endl. }\end{array}$ & Burseraceae & $\begin{array}{l}\text { Hairy corkwood, Namibian } \\
\text { corkwood (English), harige } \\
\text { kanniedood (Afrikaans) }\end{array}$ & Bark & $\begin{array}{l}\text { A decoction is used } \\
\text { to treat diabetes. }\end{array}$ & Khumalo, 2018. \\
\hline
\end{tabular}




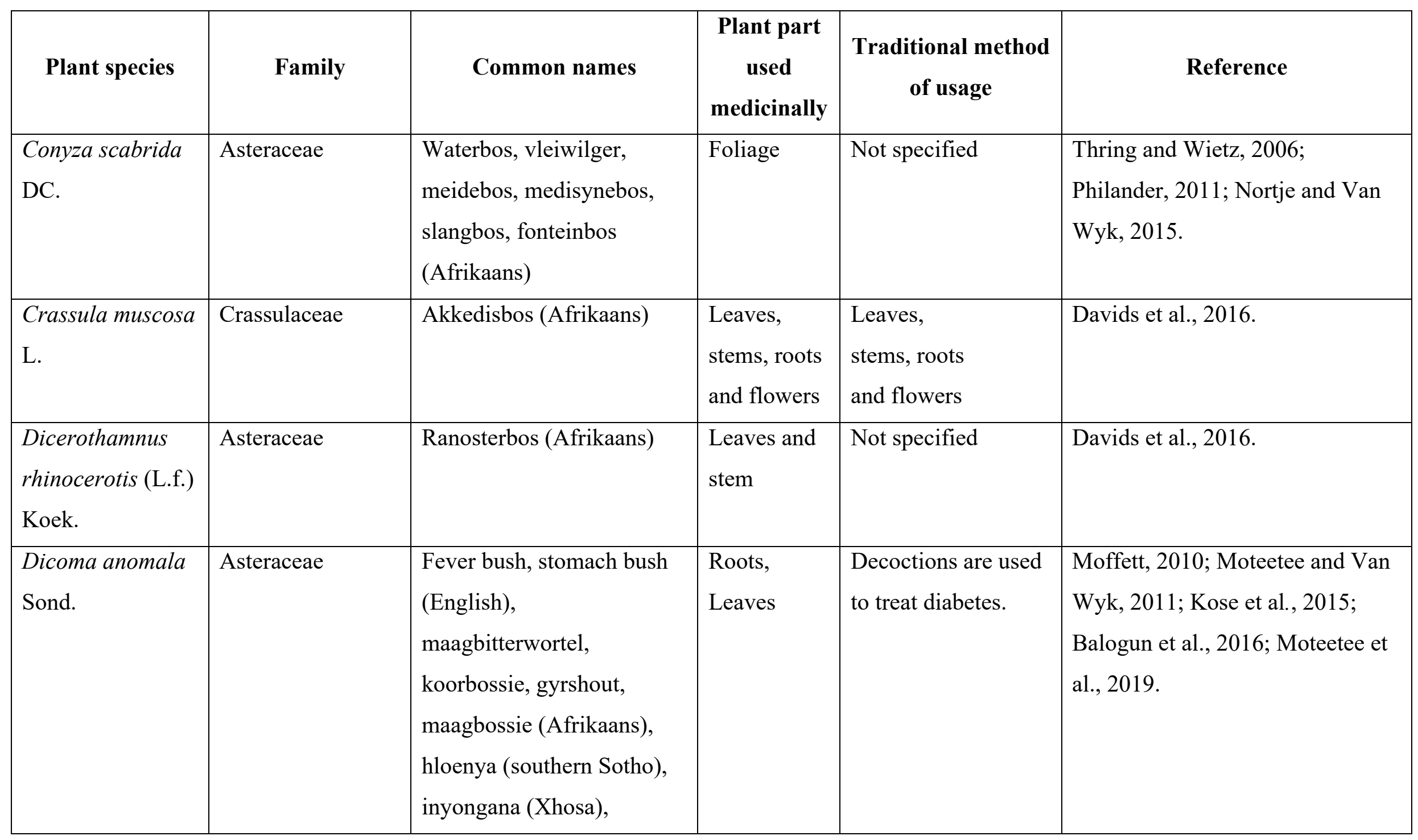




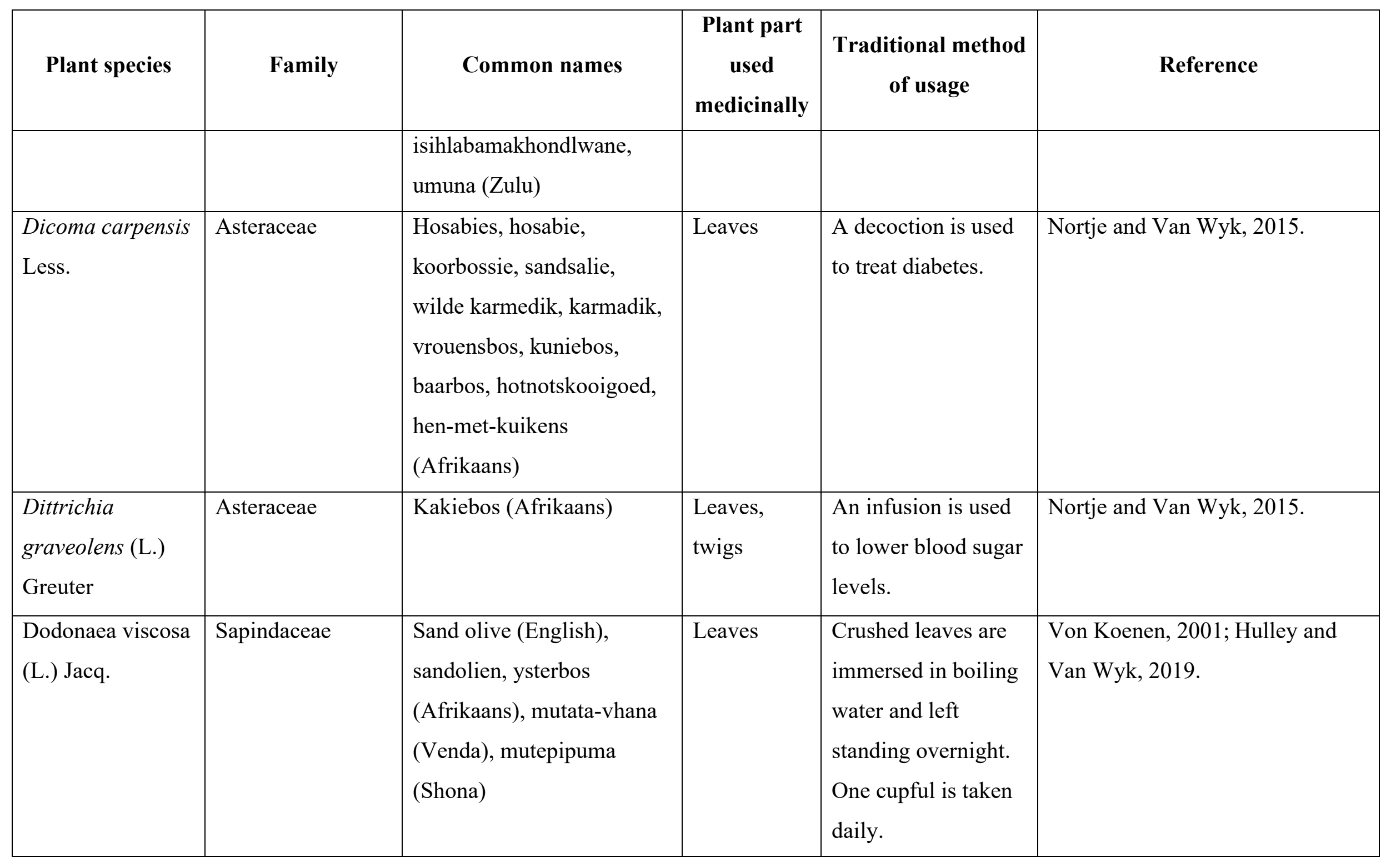




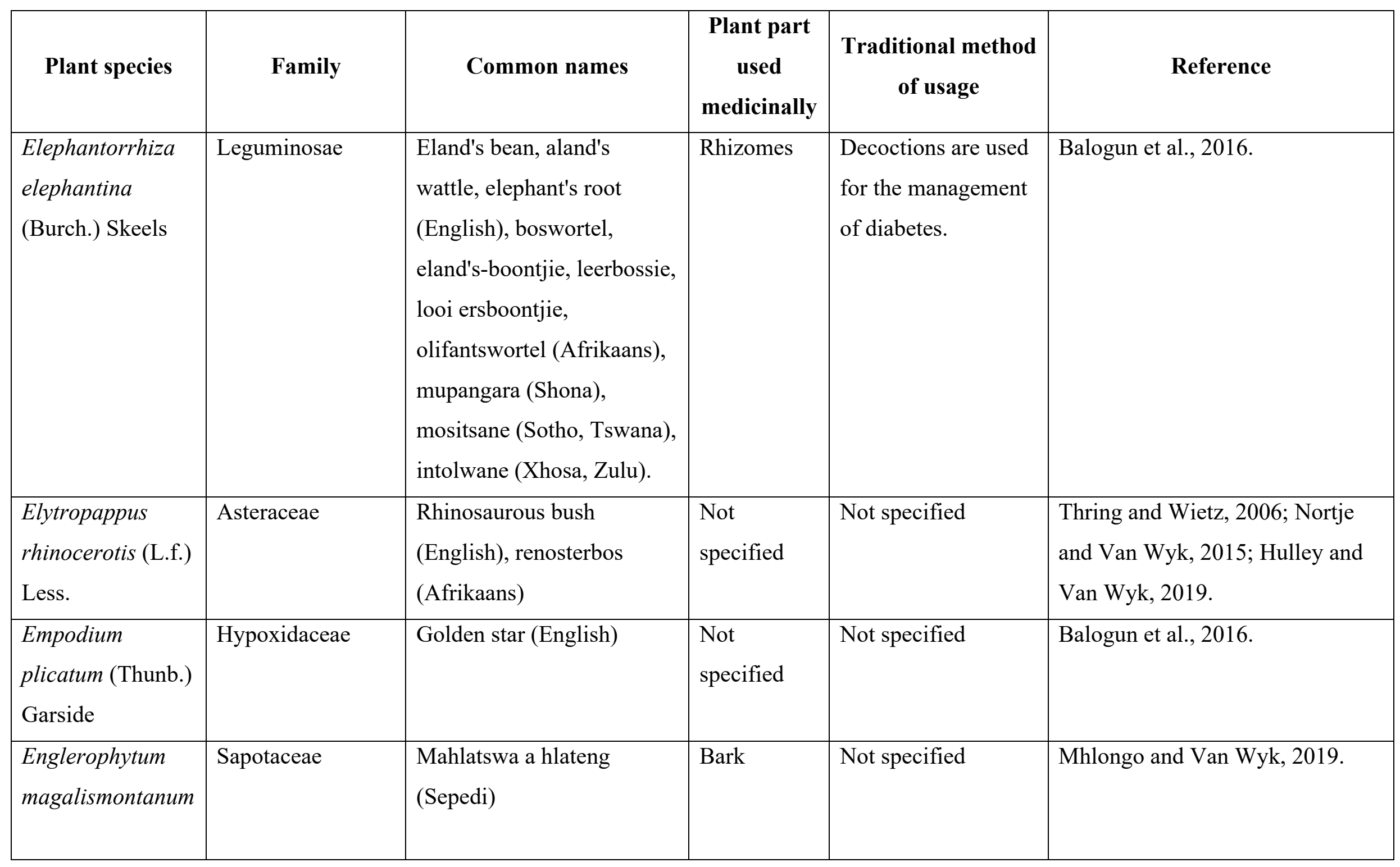




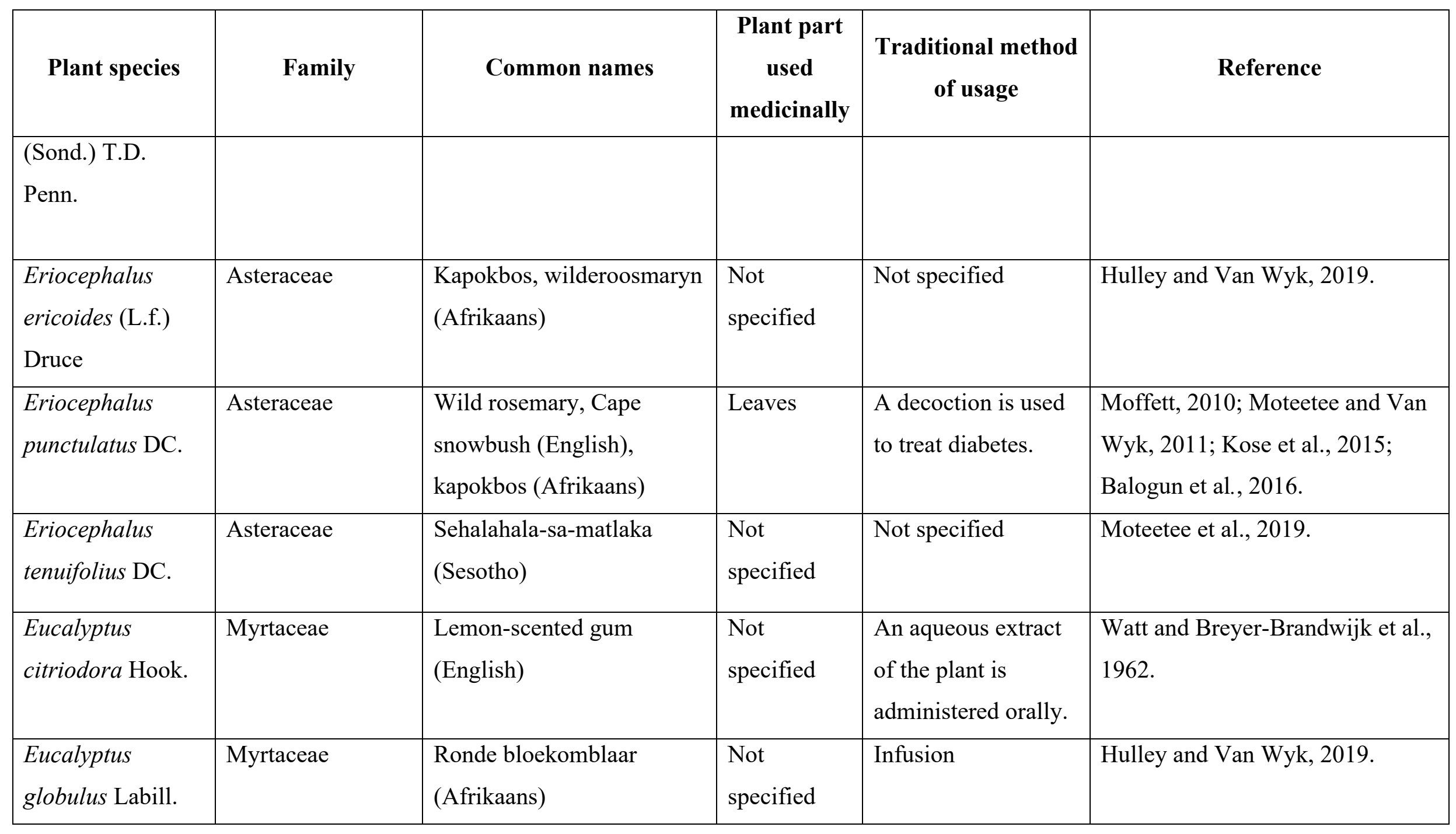




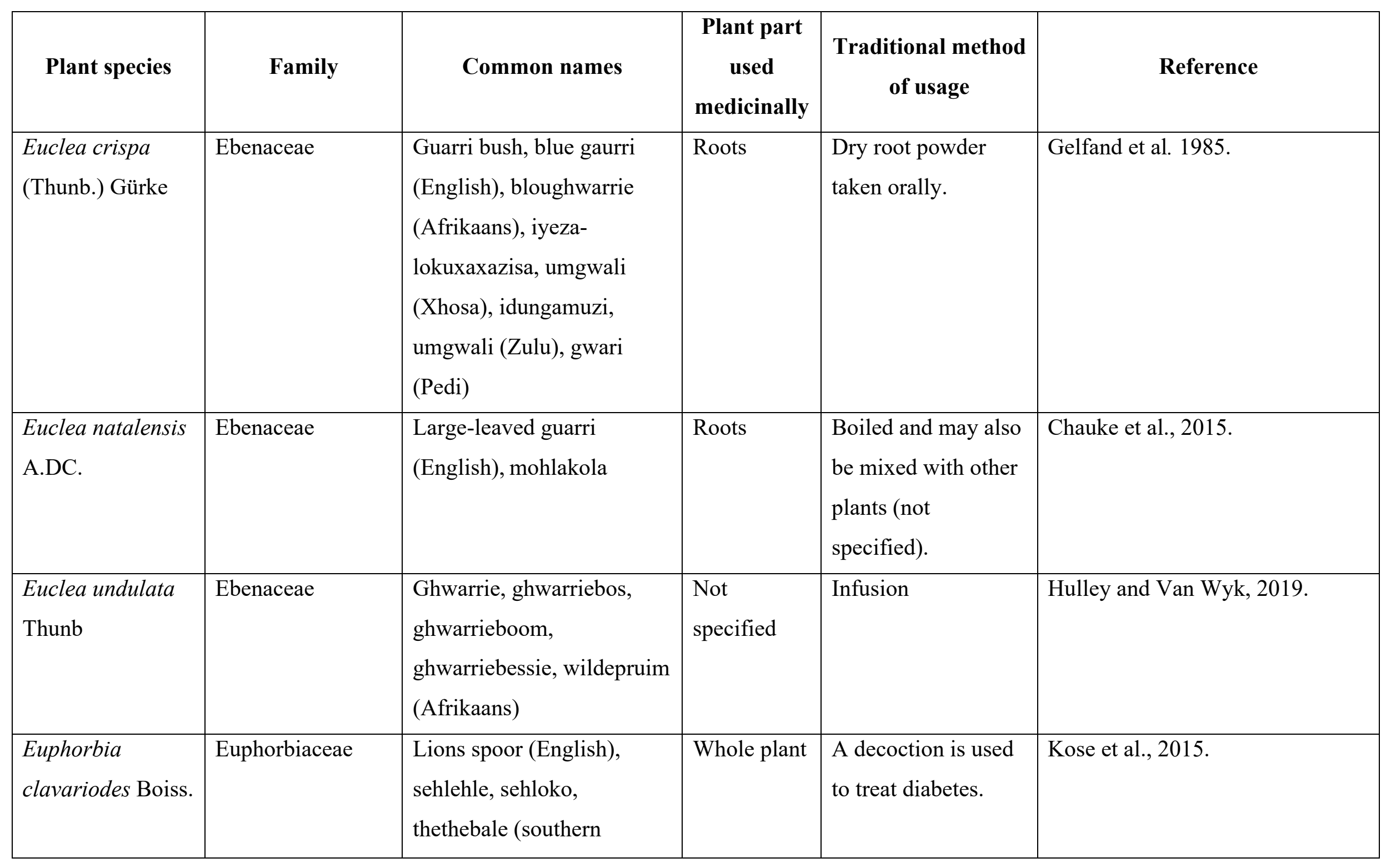




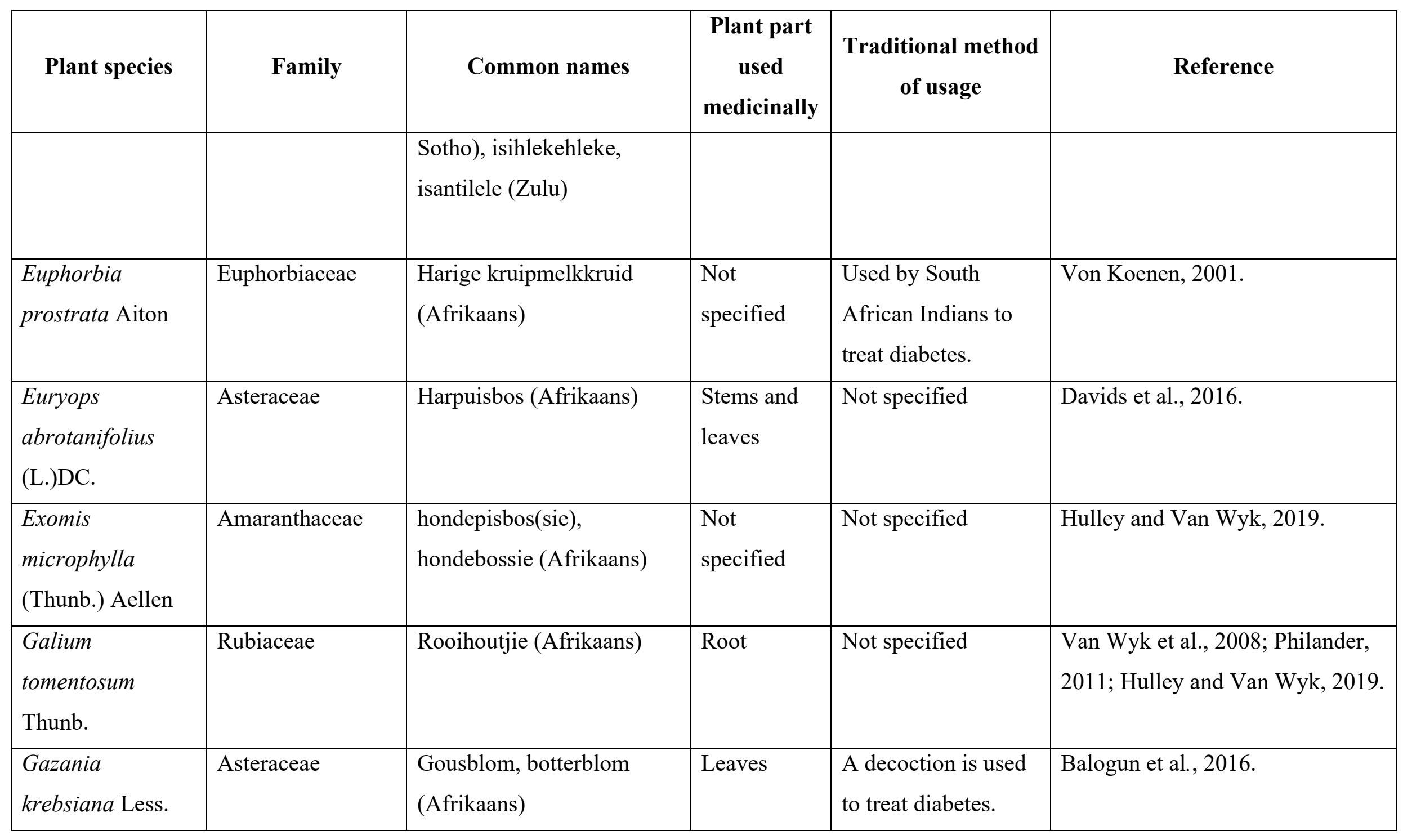




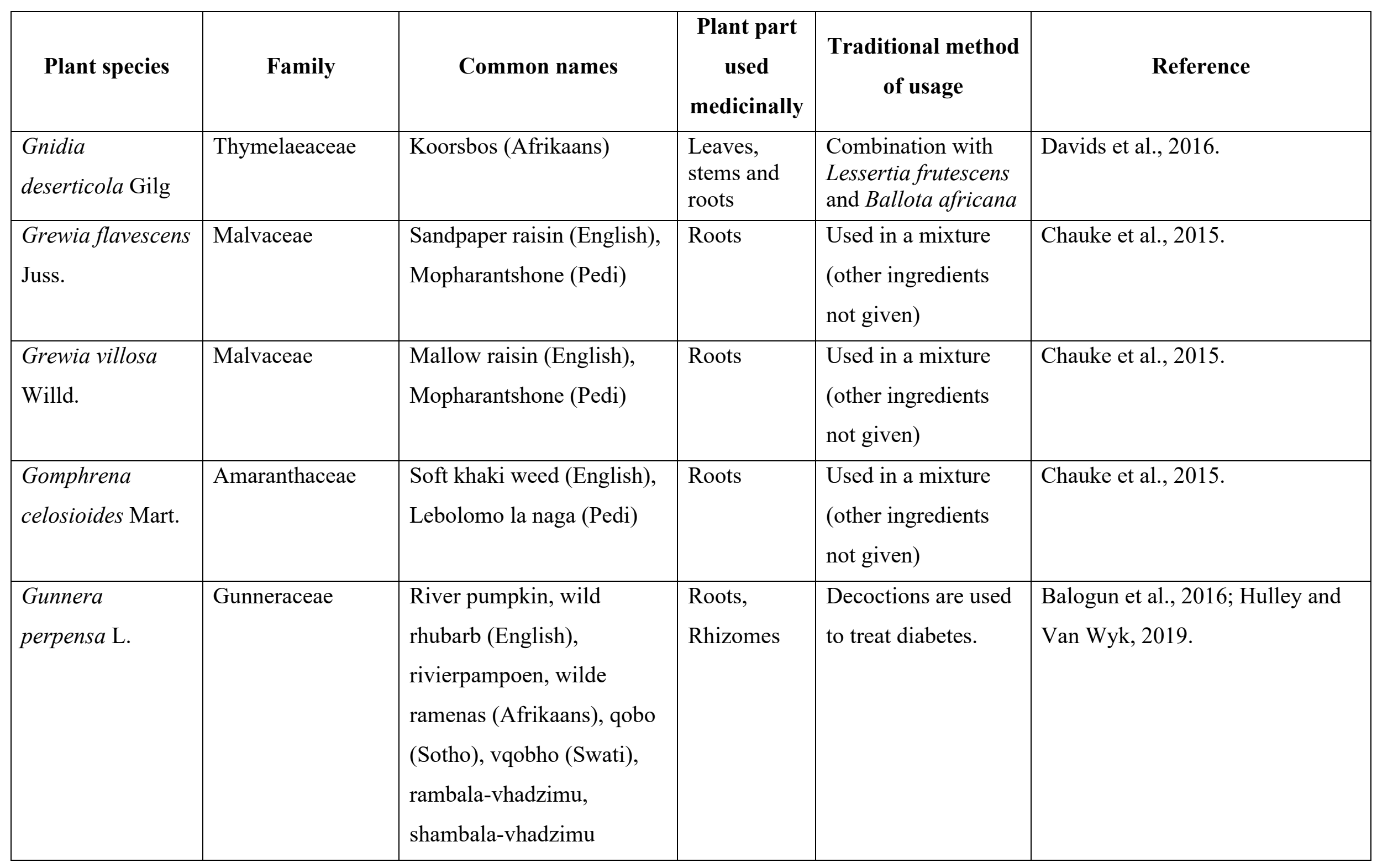




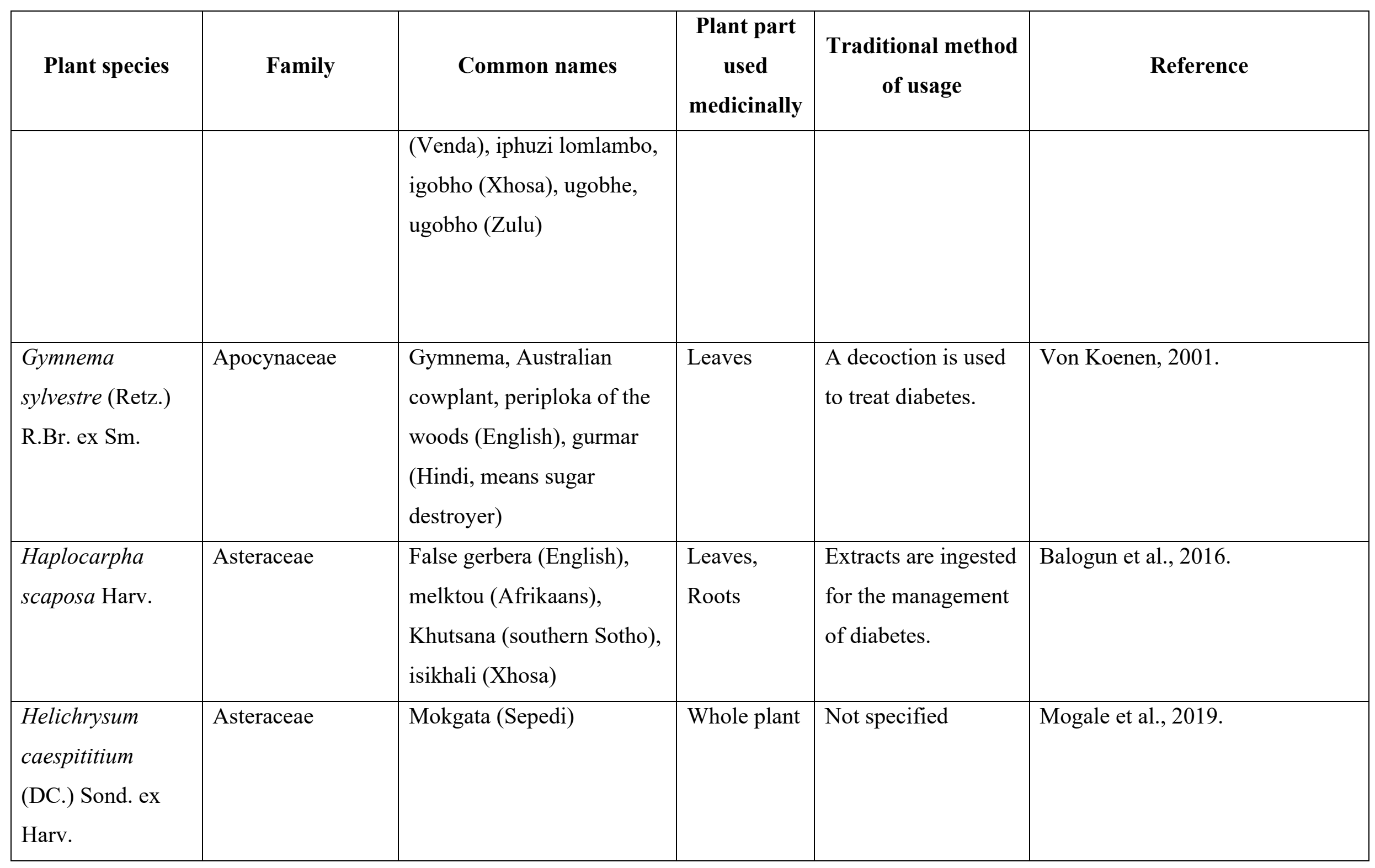




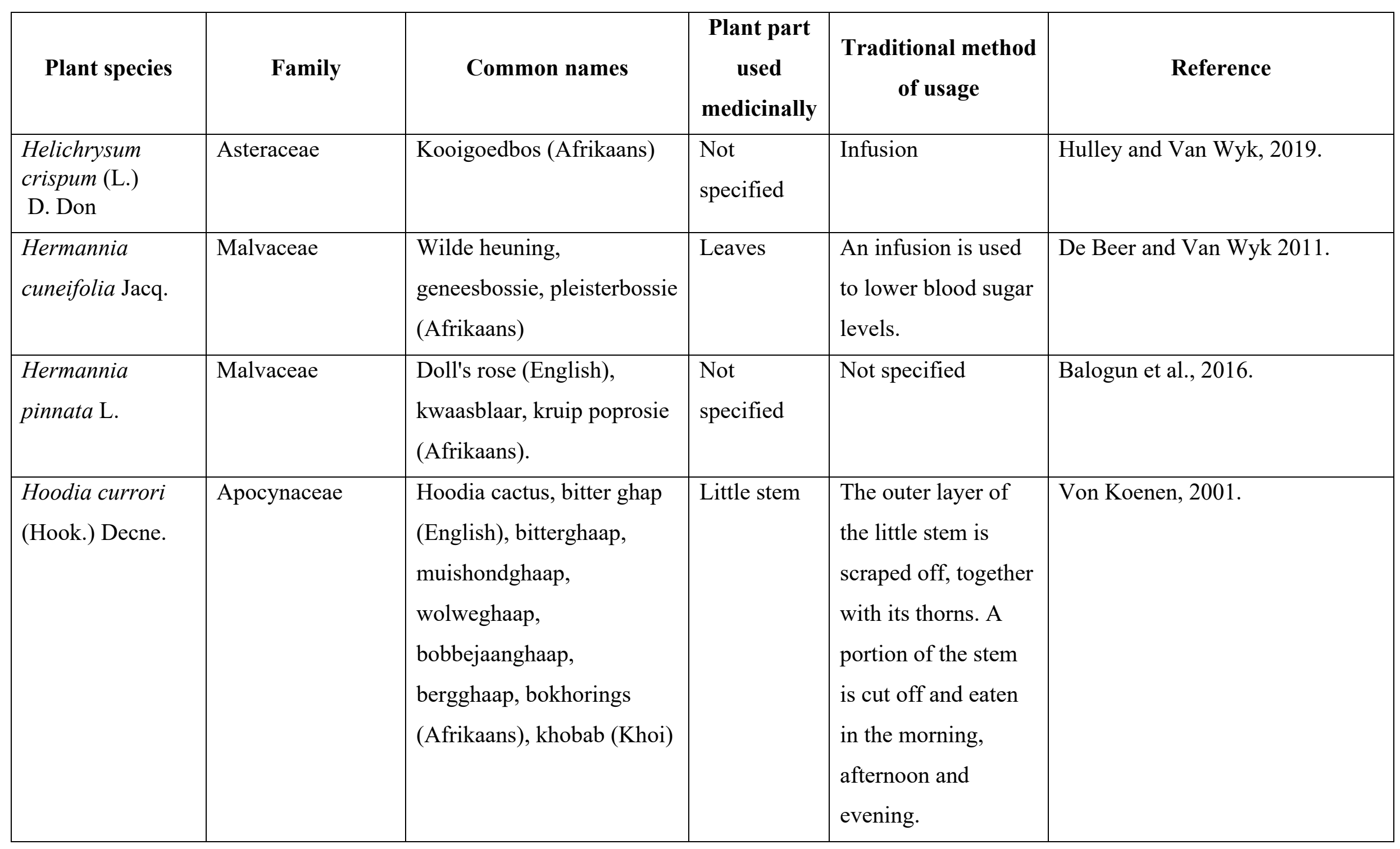




\begin{tabular}{|c|c|c|c|c|c|}
\hline Plant species & Family & Common names & $\begin{array}{c}\text { Plant part } \\
\text { used } \\
\text { medicinally }\end{array}$ & $\begin{array}{c}\text { Traditional method } \\
\text { of usage }\end{array}$ & Reference \\
\hline $\begin{array}{l}\text { Inula graveolens } \\
\text { (L.)Desf. }\end{array}$ & Asteraceae & Khakibos (Afrikaans) & Foliage & Not specified & Philander, 2011. \\
\hline $\begin{array}{l}\text { Jacobaea } \\
\text { maritima (L.) } \\
\text { Pelser \& Meijden }\end{array}$ & Asteraceae & Vaalbos (Afrikaans) & $\begin{array}{l}\text { Not } \\
\text { specified }\end{array}$ & Not specified & Hulley and Van Wyk, 2019. \\
\hline
\end{tabular}




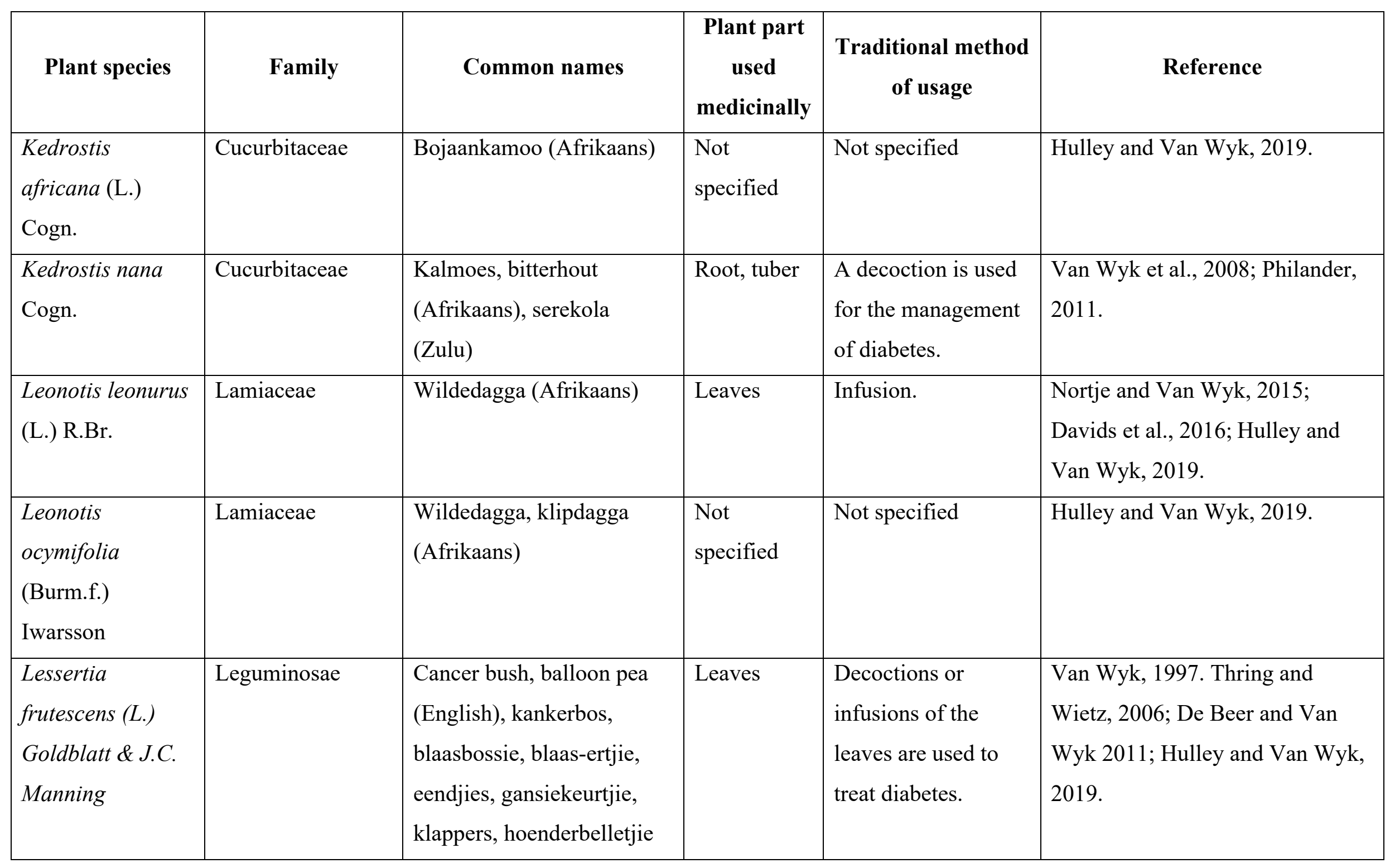




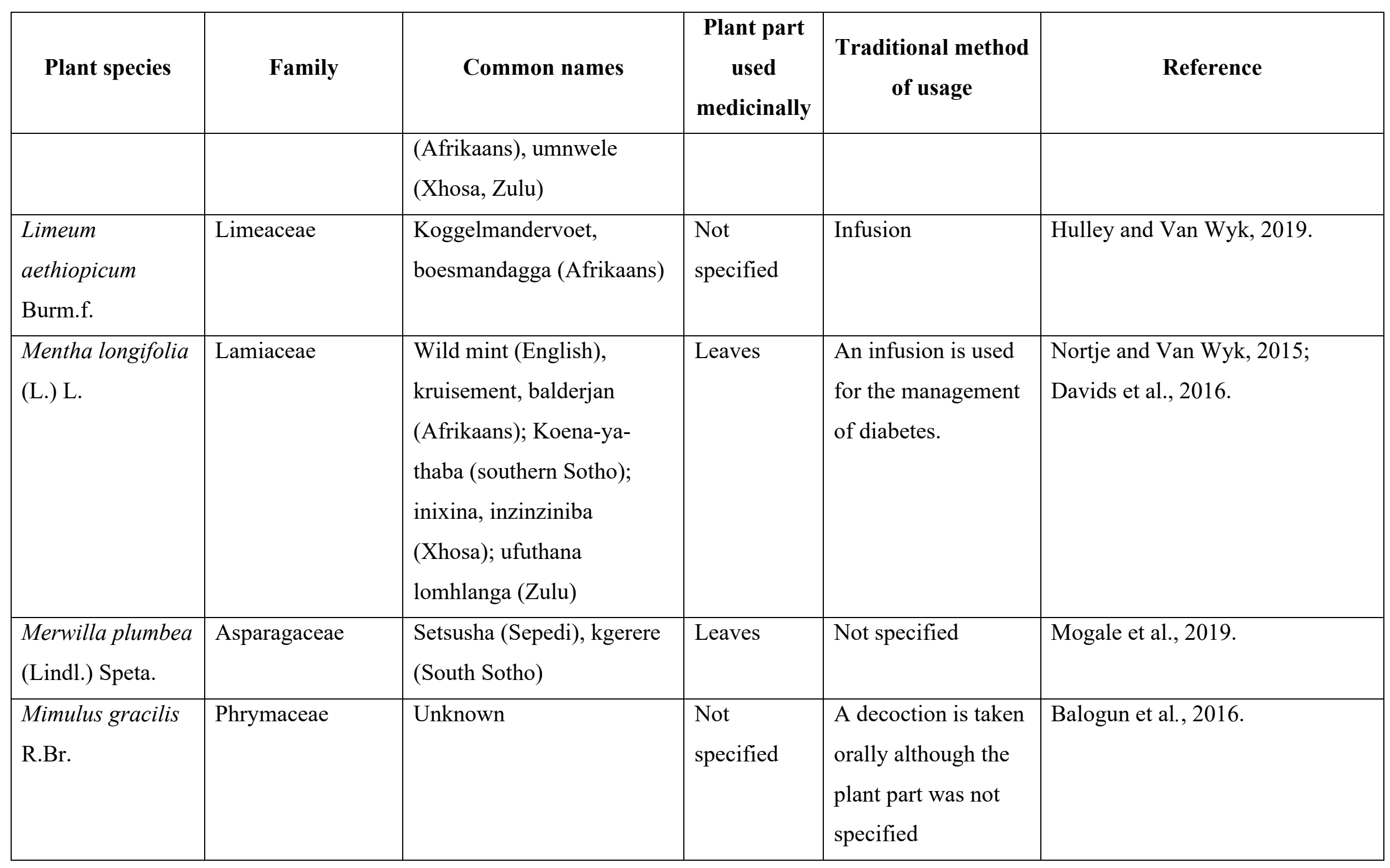




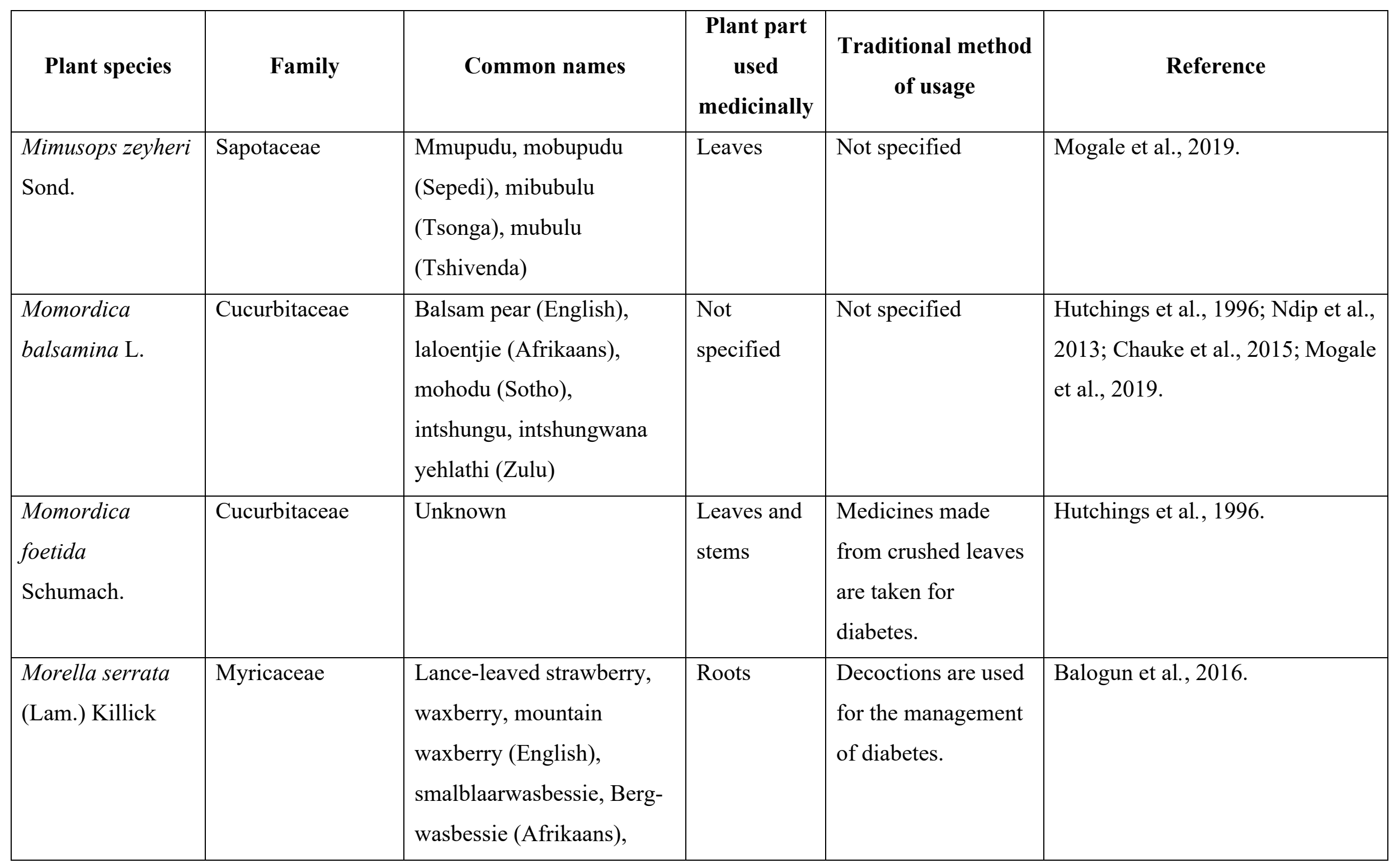




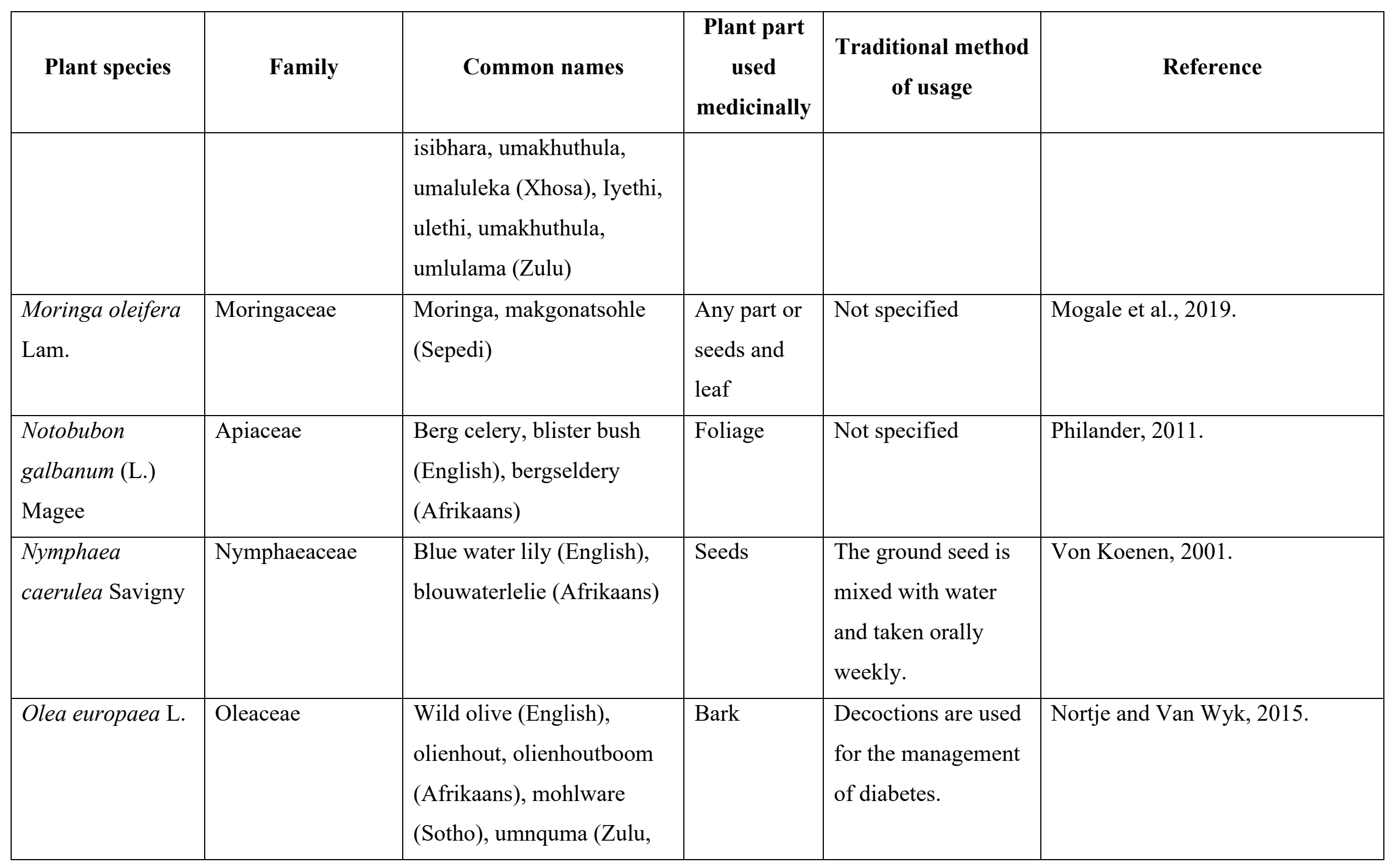




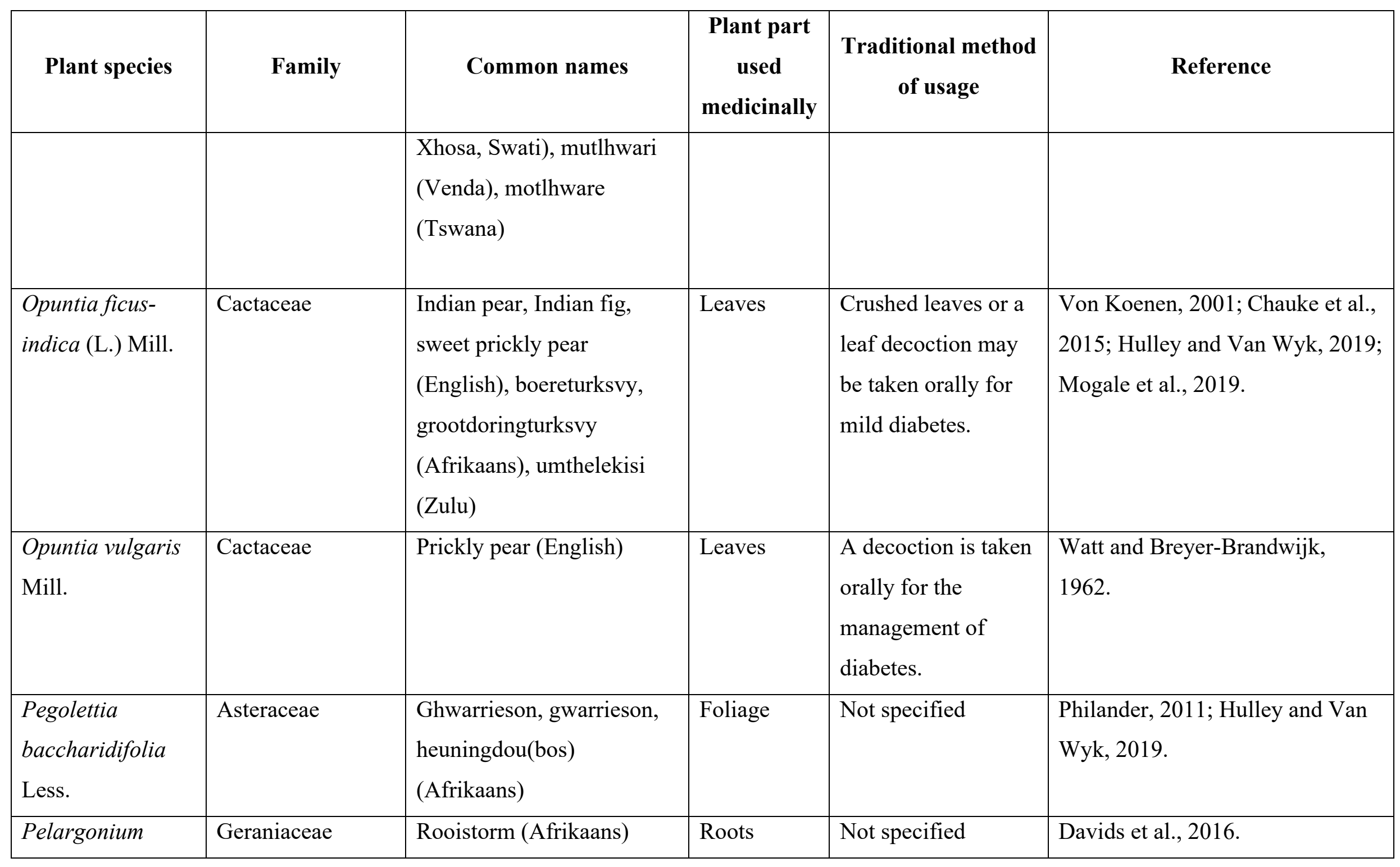




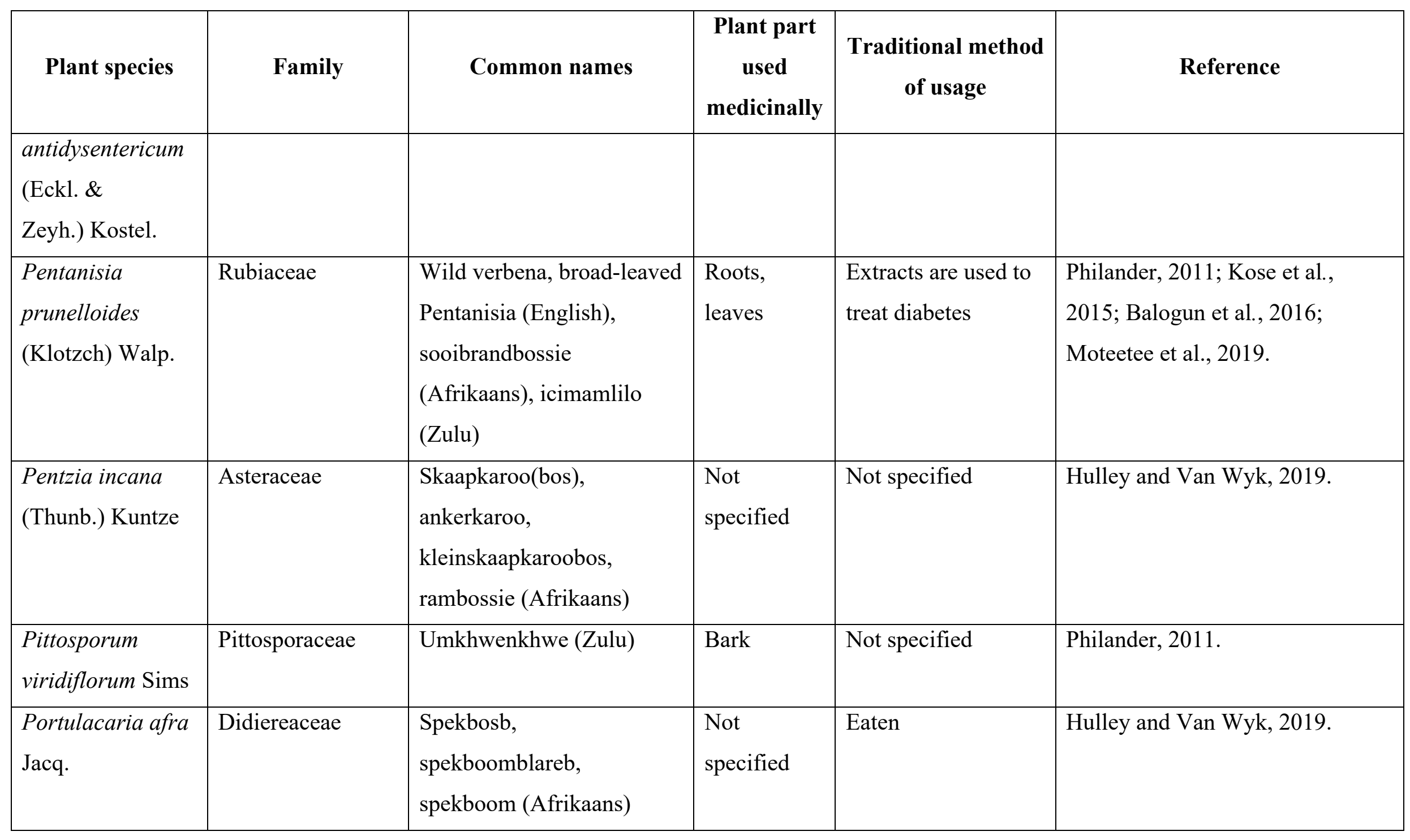




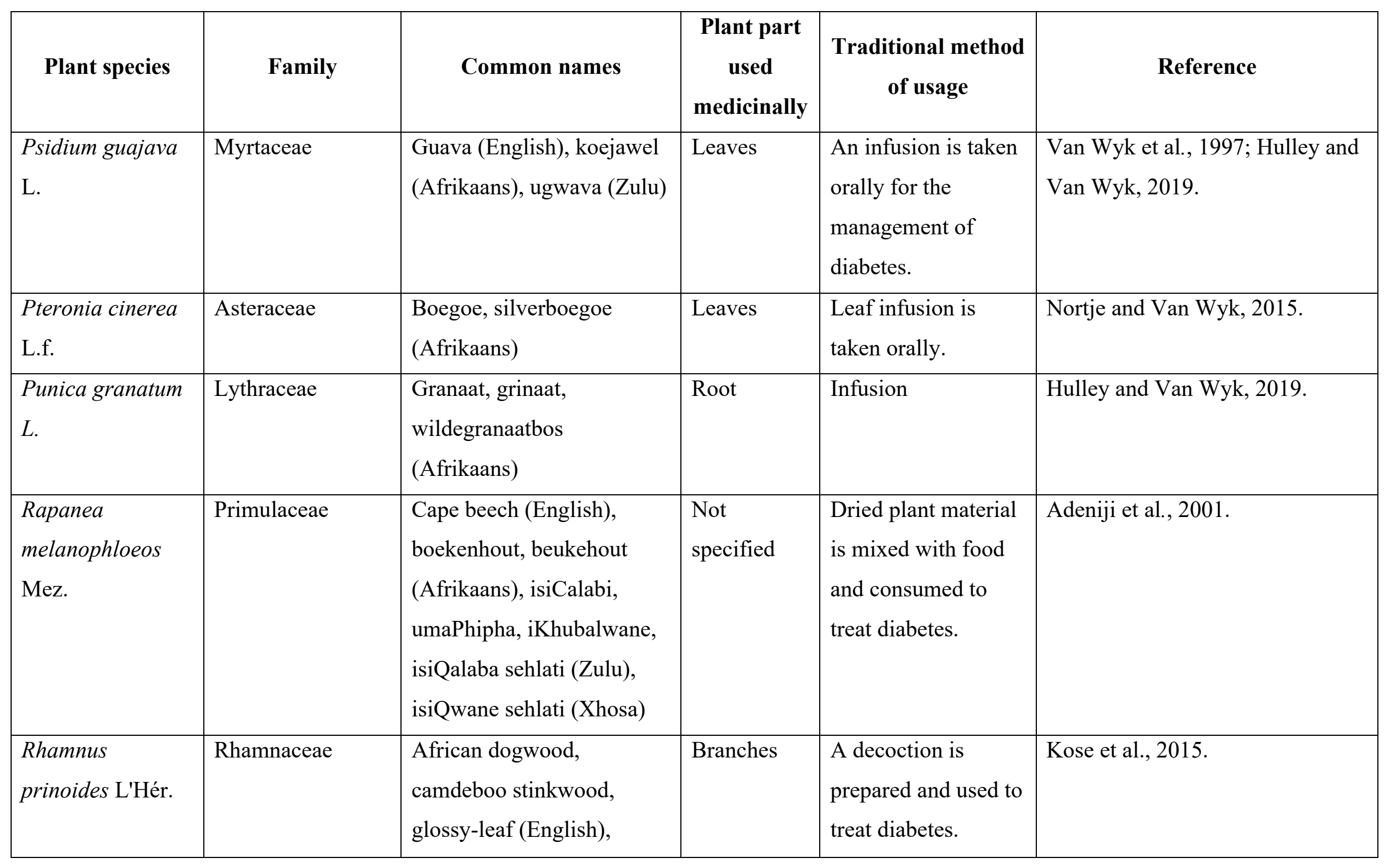




\begin{tabular}{|c|c|c|c|c|c|}
\hline Plant species & Family & Common names & $\begin{array}{c}\text { Plant part } \\
\text { used } \\
\text { medicinally }\end{array}$ & $\begin{array}{c}\text { Traditional method } \\
\text { of usage }\end{array}$ & Reference \\
\hline $\begin{array}{l}\text { Rosmarinus } \\
\text { officinalis } \mathrm{L} .\end{array}$ & Lamiaceae & $\begin{array}{l}\text { Rosemary (English), } \\
\text { roosmaryn (Afrikaans) }\end{array}$ & $\begin{array}{l}\text { Not } \\
\text { specified }\end{array}$ & $\begin{array}{l}\text { An infusion is } \\
\text { prepared and } \\
\text { consumed. }\end{array}$ & Van Wyk et al., 2008. \\
\hline $\begin{array}{l}\text { Ruta graveolens } \\
\text { L. }\end{array}$ & Rutaceae & $\begin{array}{l}\text { Rue, common rue, herb-of- } \\
\text { grace (English), wynruit } \\
\text { (Afrikaans) }\end{array}$ & Leaves & Infusion is used. & $\begin{array}{l}\text { Thring and Wietz, 2006; Nortje } \\
\text { and Van Wyk, 2015; Van Wyk } \\
\text { and Gorelik, } 2017 .\end{array}$ \\
\hline
\end{tabular}




\begin{tabular}{|c|c|c|c|c|c|}
\hline Plant species & Family & Common names & $\begin{array}{c}\text { Plant part } \\
\text { used } \\
\text { medicinally }\end{array}$ & $\begin{array}{c}\text { Traditional method } \\
\text { of usage }\end{array}$ & Reference \\
\hline $\begin{array}{l}\text { Salvia dentata } \\
\text { Aiton }\end{array}$ & Lamiaceae & $\begin{array}{l}\text { Toothed sage (English), } \\
\text { bergsalie, blousalie, } \\
\text { bloublomsalie, salie, } \\
\text { sandsalie (Afrikaans) }\end{array}$ & $\begin{array}{l}\text { Not } \\
\text { specified }\end{array}$ & $\begin{array}{l}\text { A syrup is prepared } \\
\text { and used. }\end{array}$ & Nortje and Van Wyk, 2015. \\
\hline $\begin{array}{l}\text { Schkuhria pinnata } \\
\text { (Lam.) Kuntze ex } \\
\text { Thell. }\end{array}$ & Asteraceae & $\begin{array}{l}\text { Dwarf Mexican marigold } \\
\text { (English), klein-gousblom, } \\
\text { kleinkakiebos (Afrikaans), } \\
\text { ruhwahwa (Shona) }\end{array}$ & $\begin{array}{l}\text { Whole } \\
\text { plant, leaves } \\
\text { or roots }\end{array}$ & $\begin{array}{l}\text { The whole plant is } \\
\text { boiled and } \\
\text { consumed orally. }\end{array}$ & Mahwasane et al., 2013. \\
\hline
\end{tabular}




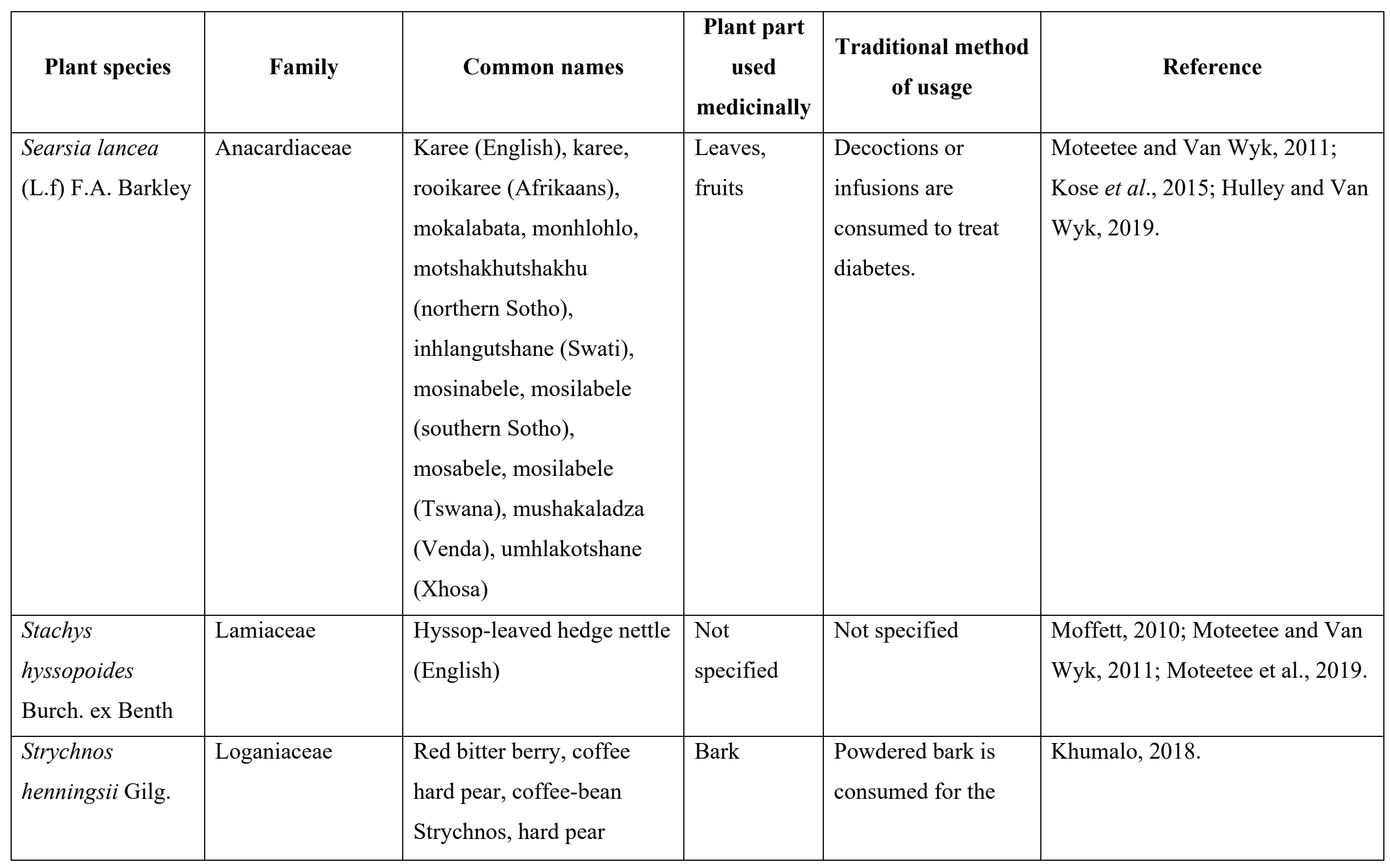




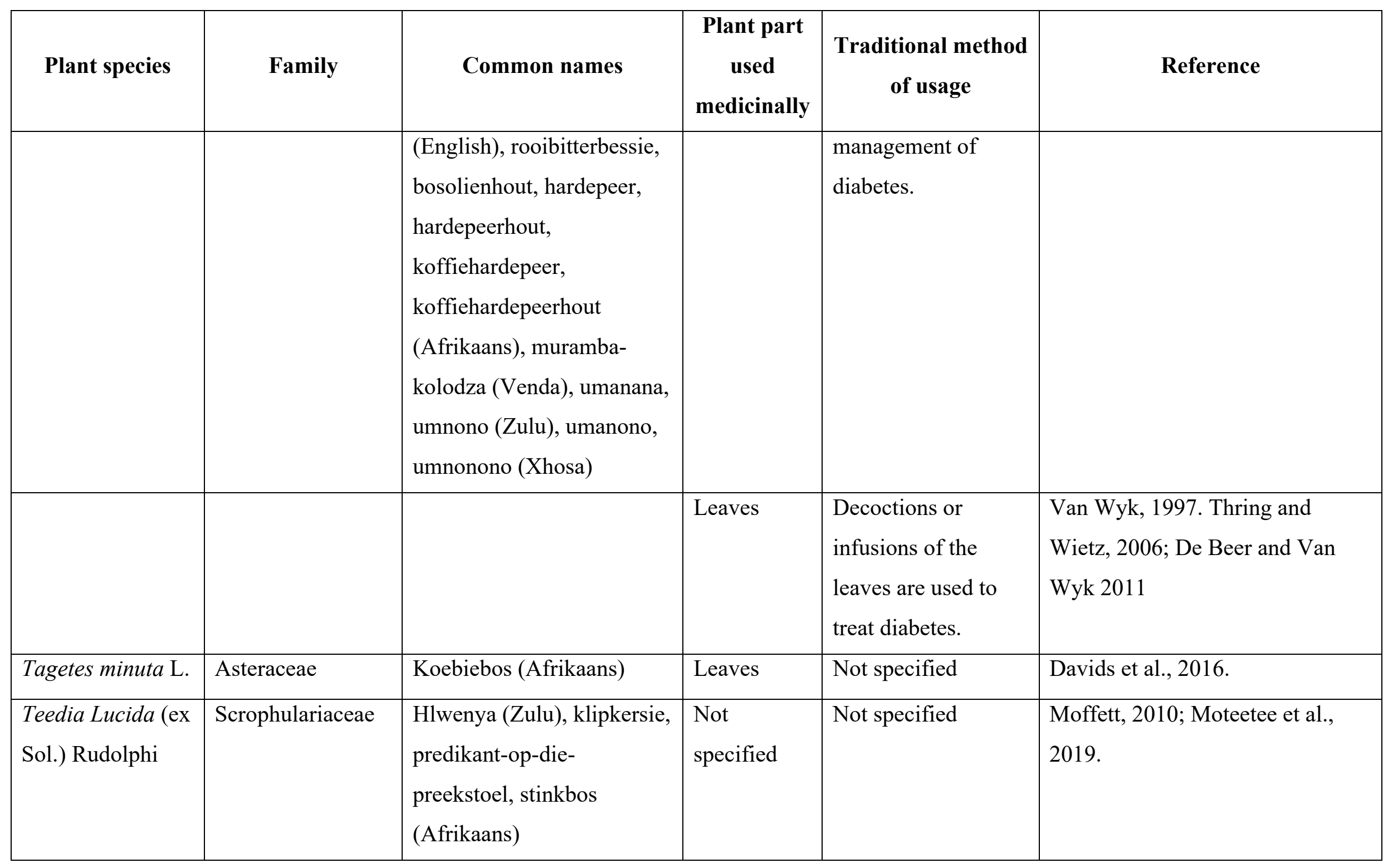




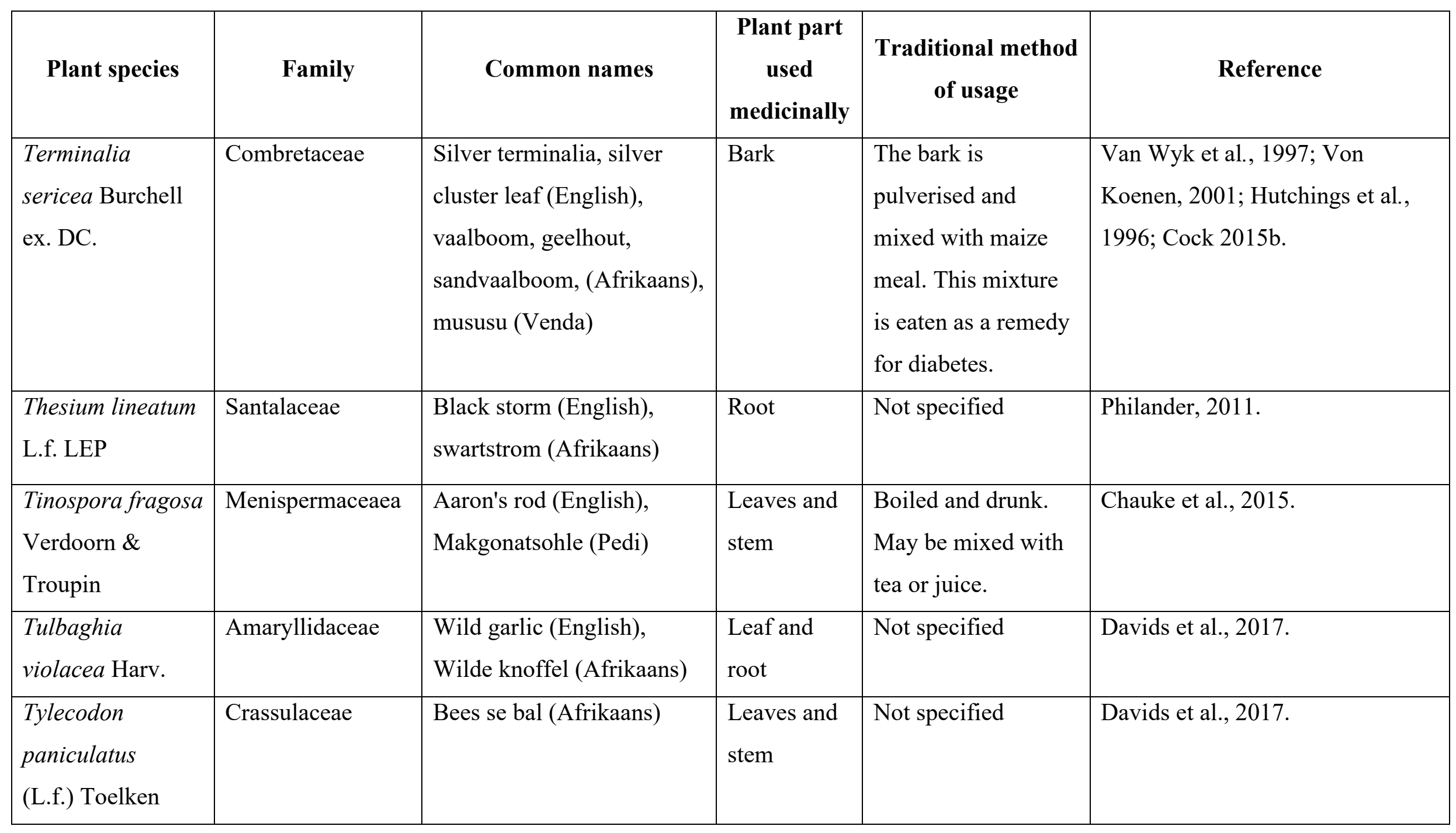




\begin{tabular}{|c|c|c|c|c|c|}
\hline Plant species & Family & Common names & $\begin{array}{l}\text { Plant part } \\
\text { used } \\
\text { medicinally }\end{array}$ & $\begin{array}{c}\text { Traditional method } \\
\text { of usage }\end{array}$ & Reference \\
\hline Urtica urens $L$. & Urticaceae & $\begin{array}{l}\text { Brandnekel(boom), } \\
\text { brandneker, netelbos } \\
\text { (English) }\end{array}$ & $\begin{array}{l}\text { Not } \\
\text { specified }\end{array}$ & Infusion & Hulley and Van Wyk, 2019. \\
\hline $\begin{array}{l}\text { Viscum capense } \\
\text { L.f. }\end{array}$ & Santalaceae & $\begin{array}{l}\text { Cape mistletoe (English), } \\
\text { groen voelent, taaibos } \\
\text { (Afrikaans) }\end{array}$ & Stem & $\begin{array}{l}\text { Stem infusions are } \\
\text { used to treat } \\
\text { diabetes. }\end{array}$ & $\begin{array}{l}\text { Van Wyk, 1997; De Beer and Van } \\
\text { Wyk 2011; Hulley and Van Wyk, } \\
2019 .\end{array}$ \\
\hline $\begin{array}{l}\text { Viscum continuum } \\
\text { E. Mey. ex } \\
\text { Sprague }\end{array}$ & Santalaceae & $\begin{array}{l}\text { Voëlent, litjiestee } \\
\text { (Afrikaans) }\end{array}$ & $\begin{array}{l}\text { Not } \\
\text { specified }\end{array}$ & Infusion & Hulley and Van Wyk, 2019. \\
\hline
\end{tabular}




\begin{tabular}{|c|c|c|c|c|c|}
\hline Plant species & Family & Common names & $\begin{array}{c}\text { Plant part } \\
\text { used } \\
\text { medicinally }\end{array}$ & $\begin{array}{c}\text { Traditional method } \\
\text { of usage }\end{array}$ & Reference \\
\hline $\begin{array}{l}\text { Ziziphus } \\
\text { mucronata Willd. }\end{array}$ & Rhamnaceae & $\begin{array}{l}\text { Motalo, mokgalo (Sepedi), } \\
\text { makhalu (Tshivenda), } \\
\text { nceseni (Tsonga) }\end{array}$ & Root & Not specified & Mogale et al., 2019. \\
\hline
\end{tabular}




\section{Scientific studies into the anti-diabetes mellitus activity of South African plants}

Several laboratory-based studies have aimed to verify the efficacy of South African plant species and to determine to their anti-DM mechanisms (Table 3). Most of these studies have examined the effects in DM-induced animal models, especially in rats, mice and rabbits.

The Aloe species have been perhaps the most extensively studied. Administration of $1000 \mathrm{mg} / \mathrm{kg}$ body weight of $A$. arborescens juice decreased blood glucose levels by $8.4 \%$ after $6 \mathrm{~h}$ (Chacko et al., 2008). Continuous administration proved to be effective, with reductions of $26.9 \%$ at $200 \mathrm{mg} / \mathrm{kg}$ body weight and $42.3 \%$ at $1000 \mathrm{mg} / \mathrm{kg}$ body weight observed after 18 days. In another study, an A. arborescens leaf fraction significantly suppressed blood glucose levels in streptozotocin-induced diabetic mice (Amoo et al., 2014). Similarly, an A. ferox leaf extract (300 mg/kg body weight) increased insulin levels in streptozotocin induced diabetic rats (Loots et al., 2011; Amoo et al., 2014). Surprisingly, no changes in the hyperglycaemic state were observed, despite the increased insulin secretion.

The antihyperglycemic activity of $A$. cepa juice has also been particularly well reported. The therapeutic properties have been verified in alloxan-induced rats, lowering of plasma glucose levels by approximately 70\% (El-Dermerdash et al., 2005). Similarly, A. cepa essential oil substantially reduces blood sugar levels and raises insulin secretion (El-Soud and Khalil, 2010). Upon administration of $A$. cepa to alloxan induced rats for six weeks, it was found that the effect is dose dependant (Ozougwu, 2011). At $200 \mathrm{mg} / \mathrm{kg}$ body weight, blood glucose levels were reduced by $62.9 \%$, at $250 \mathrm{mg} / \mathrm{kg}$ they were reduced by $69.7 \%$ and at $300 \mathrm{mg} / \mathrm{kg}$ they were reduced by $75.4 \%$. In another study, $A$. cepa administration resulted in a significant reduction in induced hyperglycaemia by approximately $120 \mathrm{mg} / \mathrm{dL}$ after $4 \mathrm{~h}$ (Taj Eldin et al., 2010). The administration of $100 \mathrm{mg} / \mathrm{kg}$ body weight of crude $A$. cepa extract lowered fasting blood glucose levels in diabetic patients by $40 \mathrm{mg} / \mathrm{dL}$. A relatively gradual decrease in fasting blood 
glucose was also observed for the same period compared to insulin therapy in type 1 diabetic patients. Administration of an ether extract of $A$. cepa to diabetic rabbits showed antihyperglycemic activity (Ogunmodede et al., 2012). Similarly, increasing dosages (100 and $300 \mathrm{mg} / \mathrm{kg}$ body weight) of the aqueous extract of $A$. cepa resulted in significant reductions of fasting glucose levels of $53.3 \%$ and $73.3 \%$ respectively. The reduction in blood glucose level observed in rabbits treated with $A$. cepa after four weeks of treatment showed potential for complete recovery over an extended period of administration in the same study.

The therapeutic effects of $A$. occidentale stem-bark extracts have been reported in fructose-diabetic rats. Rats receiving a single daily intravenous dose of $200 \mathrm{mg} / \mathrm{kg}$ body weight of A. occidentale methanol extract had significantly lower plasma glucose levels compared to the control rats on a high-fructose diet (Olatunji et al., 2010). That report linked the antihyperglycemic effect of the extract to high antioxidant capacities. Similarly, the administration of alcoholic $A$. occidentale bark extracts resulted in the reduction of serum glucose levels. Indeed, treatment with $300 \mathrm{mg} / \mathrm{kg}$ body weight reduced the blood sugar levels by $18.4 \%, 200 \mathrm{mg} / \mathrm{kg}$ reduced them by $17.3 \%$ and $12.8 \%$ depending on the weight of the rats, whilst $30 \mathrm{mg} / \mathrm{kg}$ produced a reduction of $15.6 \%$ (Fagbohun and Odufunwa, 2010; Ukwenya et al., 2012).

Other studies conducted on streptozotocin-induced diabetic rats showed that $A$. afra aqueous extracts significantly reduced blood glucose levels (Afolayan and Sunmonu, 2011; Afolayan and Sunmonu, 2013). Notably, following 21 days of administration, the glucose levels tended towards normalcy. Saponins that have been reported to exhibit hypoglycaemic effects in diabetic rabbits were detected in the A. afra aqueous extract and were postulated to be responsible for the activity of that extract. Similarly, B. discolor methanolic extracts induced a time dependent decrease in the blood glucose levels in streptozotocin-induced diabetic rats at 200 and $600 \mathrm{mg} / \mathrm{kg}$ body weight (Mellem et al., 2013). The higher dose of $600 \mathrm{mg} / \mathrm{kg}$ 
produced more pronounced effects than the reference drug metformin. Similarly, the related species B. elliptica also decreased blood glucose levels in L6 myoblast cells (Sagbo et al 2018), suggesting that $B$. elliptica functions by a similar mechanism to metformin. An increase in glucose uptake was reported in HepG2 cells in a dose-dependent manner in that study.

A different study reported that methanolic $C$. roseus leaf extracts significantly reduce blood glucose levels by $41.7 \%$ in streptozotocin-induced diabetic mice (Ojewole and Adewumni, 2000). In another study, administration of an aqueous $C$. roseus extract $(1 \mathrm{~g} / \mathrm{kg}$ body weight) for 21 days streptozotocin-induced rats decreased blood glucose levels by $20.2 \%$ (Singh et al., 2001). Similarly, the same study reported that a dichloromethane/methanol extract ( $500 \mathrm{mg} / \mathrm{kg}$ body weight) decreased blood glucose levels by $48.6 \%$ and $57.6 \%$ at 7 and 15 days respectively. The extract also resulted in a 30 min delay in peak blood glucose levels reaching a peak.

Administration of C. africana extracts to alloxan-induced diabetic rats reduced fasting blood glucose from $408.5 \mathrm{mg} / \mathrm{dL}$ (hyperglycaemia) to $90 \mathrm{mg} / \mathrm{dL}$ (normoglycemia) (Agunbiande et al., 2012; Balogun et al., 2016). This 78\% reduction is comparable to that of glibenclamide, which produced a reduction of $69.2 \%$ over a period of seven days. Those studies also determined that the extract inhibited the absorption of glucose through the gut lumen, directly stimulated glycolysis in peripheral tissues, reduced hepatic gluconeogenesis, facilitated glucose entry into peripheral cells and reduced plasma glucagon levels.

The antihyperglycemic properties of aqueous $H$. hemerocallidea corm extracts have also been verified in vivo (Ojewole et al., 2005; Street and Prinsloo, 2012; Ncube et al., 2013; Boaduo et al., 2014; Balogun et al.., 2016). The extract $(50-800 \mathrm{mg} / \mathrm{kg}$ body weight) significantly reduces blood glucose levels in streptozotocin-induced rats (Ojewole et al., 2005). That study identified Hypoxis and its aglycone derivative, rooperol in the aqueous extract and have postulated that these compounds contribute to the activity of the extract. $H$. 
hemerocallidea corm acetone and ethyl acetate extracts induce higher $\alpha$-amylase inhibitory effects than the standard drug acarbose (Boaduo et al., 2014). That study also reported that the extract stimulates insulin secretion and it has been suggested that this may be responsible for the blood glucose lowering effects of the extract.

Several studies have compared the efficacy of olive leaf extracts with the standard drug glibenclamide in vivo (Eidi et al., 2008; El and Karakaya 2009; El Amin et al., 2013; Hashmi et al., 2015). The extracts and glibenclamide had similar effects when tested at $0.5 \mathrm{~g} / \mathrm{kg}$ body weight, significantly reducing serum glucose levels and increasing insulin levels in streptozotocin-induced rats towards normal values (Eidi et al., 2008). The decrease in blood glucose levels was comparable to that seen for metformin, with a reduction of $64.6 \%$ observed for the O. europaea extract (Eidi et al. 2008). Further studies identified oleuropein and related secoiridoids in the extracts and postulated that they may be responsible for this activity (El and Karakaya, 2009). In a separate study, pure oleuropein (20 mg/kg body weight) was administered to diabetic rabbits over a 16 week period, resulting in significantly decreased blood glucose levels (Al-Azzawie and Alhamdani, 2006). Oleuropein also accelerated glucose uptake into cells (Sangi et al., 2015).

Administration of aqueous $U$. dioica leaf extracts significantly reduced blood glucose levels in alloxan-induced diabetic rats (Bnouham et al., 2003). A significant reduction (67.9\%) in blood sugar levels was observed within $1 \mathrm{~h}$ of administration. In contrast, hexane, ethyl acetate and methanol extracts were less effective at lowering blood glucose levels (Ahangarpour et al., 2012; Dar et al., 2013). These studies reported reductions of $28.3 \%$ and $40 \%$ at 1 and $2 \mathrm{~h}$ after administration respectively for the methanol extract. Interestingly, the U. dioica leaf extracts also significantly reduced serum insulin secretion and fasting insulin resistance index (Ahangarpour et al., 2012; Dar et al., 2013). 
The antidiabetic properties of several other plant species used traditionally in South Africa to treat DM have also been verified in vivo. Administration of an aqueous Eucalyptus citridora Hook leaf extract at $250 \mathrm{mg} / \mathrm{kg}$ and $500 \mathrm{mg} / \mathrm{kg}$ body weight significantly reduced blood glucose levels in a diabetic rat model (Arjun et al., 2009). Similarly, P. guajava has substantial hypoglycaemic activity in induced diabetic rats, although it was not effective on normal rats (Afolayan and Sunmonu, 2010). Treatment of streptozotocin-induced diabetic rats with L. leonurus extracts for 15 days significantly reduced blood glucose levels by a comparable extent to that of the standard drug glibenclamide (Oyedemi et al., 2010). Alcoholic G. sylvestre extracts stimulate insulin release from rat pancreatic $\beta$-cells by increasing cell permeability (Baskaran et al., 1990; Khan et al., 2011). Furthermore, an ethanolic G. sylvestre extract decreases blood glucose levels in a rat model (Baskaran et al., 1990). A clinical study conducted on Type 2 diabetic patients reported that administration of $G$. sylvestre extracts and hypoglycaemic drugs substantially improved blood sugar control at doses of 400-600 mg/day (Khan et al., 2011). Ruta graveolens extract administration in streptozotocin-induced diabetic rats induces the $\beta$-cells to return to normal functionality, thereby demonstrating an insulinogenic effect (Toserkani et al., 2012). Lessertia frutescens also has significant anti-DM effects in rats fed on a high diabetogenic diet. Shoot extracts $(0.01 \mathrm{mg} / \mathrm{g}$ body weight $)$ returned the rats insulin secretion to normal levels and substantially increased glucose clearance rates (Chadwick et al., 2007). Indeed, the L. frutescens extracts returned the experimental rats from a pre-diabetic state to normal and reversed insulin resistance. Several clinical trials have been conducted using Cinnamomum cassia Siebold extracts in diabetic patients and have reported substantial blood glucose lowering activity (Khan et al., 2003; Mang et al., 2006; Dugoua et al., 2007; Pham et al., 2007; Boaduo et al., 2013). These studies reported that the $C$. cassia extracts inhibited $\alpha$-amylase activity to a greater extent that the acarbose control, although the extracts were relatively ineffective against $\alpha$-glucosidase. 
Interestingly there is very little mention of plant combinations or mixtures to treat DM. A study by Matsabisa et al. (2019) examined the anti-diabetic potential of a locally prepared mixture of three plant species (S. birrea, O. ficus-indica and Solanum pimpinellifolium L). The mixture was shown to have a synergistic anti-hyperglycemic effect via inhibiting $\alpha$-glucosidase, DPP-IV and glycation activities as well as enhancing glucose utilisation. In vitro mechanistic studies are relatively rare for the plants identified in Table 2 . The majority of studies have examined the overall efficacy of the extracts without determining the mechanism by which they induce these reductions in blood glucose levels. It is therefore not known whether many of the extracts function via a regulation of insulin synthesis or release, or if their effects are more direct (e.g. via the direct activation of enzymes involved glucose storage and metabolism). Substantially more mechanistic studies are required to understand how these extracts achieve their effects. Indeed, for the majority of the 43 plant species whose blood glucose lowering properties have been verified, the antihyperglycemic mechanisms remain to be determined. In vitro assays were carried out to test the effects of $S$. pinnata extracts on the C2C12 myocytes, 3T3-L1 preadipocytes and Chang liver cells (Deutschlander et al., 2009). The ethanolic extract significantly lowered blood sugar levels when tested on the $\mathrm{C} 2 \mathrm{C} 12$ cells, although an acetone extract had no effect. When 3T3-L1 preadipocytes were exposed to the extracts, both $S$. pinnata ethanol and acetone extracts lowered blood glucose levels significantly. This decrease was shown to be mediated via stimulation of glucose uptake. However, the $S$. pinnata ethanol and acetone extracts were toxic to 3T3-L1 preadipocytes, raising concerns about their use medicinally. A rise in glucose utilisation was observed in differentiated 3T3-L1 cells treated with 


\section{Table 3}

Studies conducted on different plants used for the treatment of blood sugar in South Africa.*Bold denotes species found in Table 2 i.e. correlation to traditional use.

\begin{tabular}{|c|c|c|c|c|}
\hline Plant species* & Plant part used medicinally & $\begin{array}{l}\text { Type of extract } \\
\text { tested }\end{array}$ & Outcome of the study & Reference \\
\hline
\end{tabular}




\begin{tabular}{|c|c|c|c|c|}
\hline Plant species* & Plant part used medicinally & $\begin{array}{l}\text { Type of extract } \\
\text { tested }\end{array}$ & Outcome of the study & Reference \\
\hline
\end{tabular}




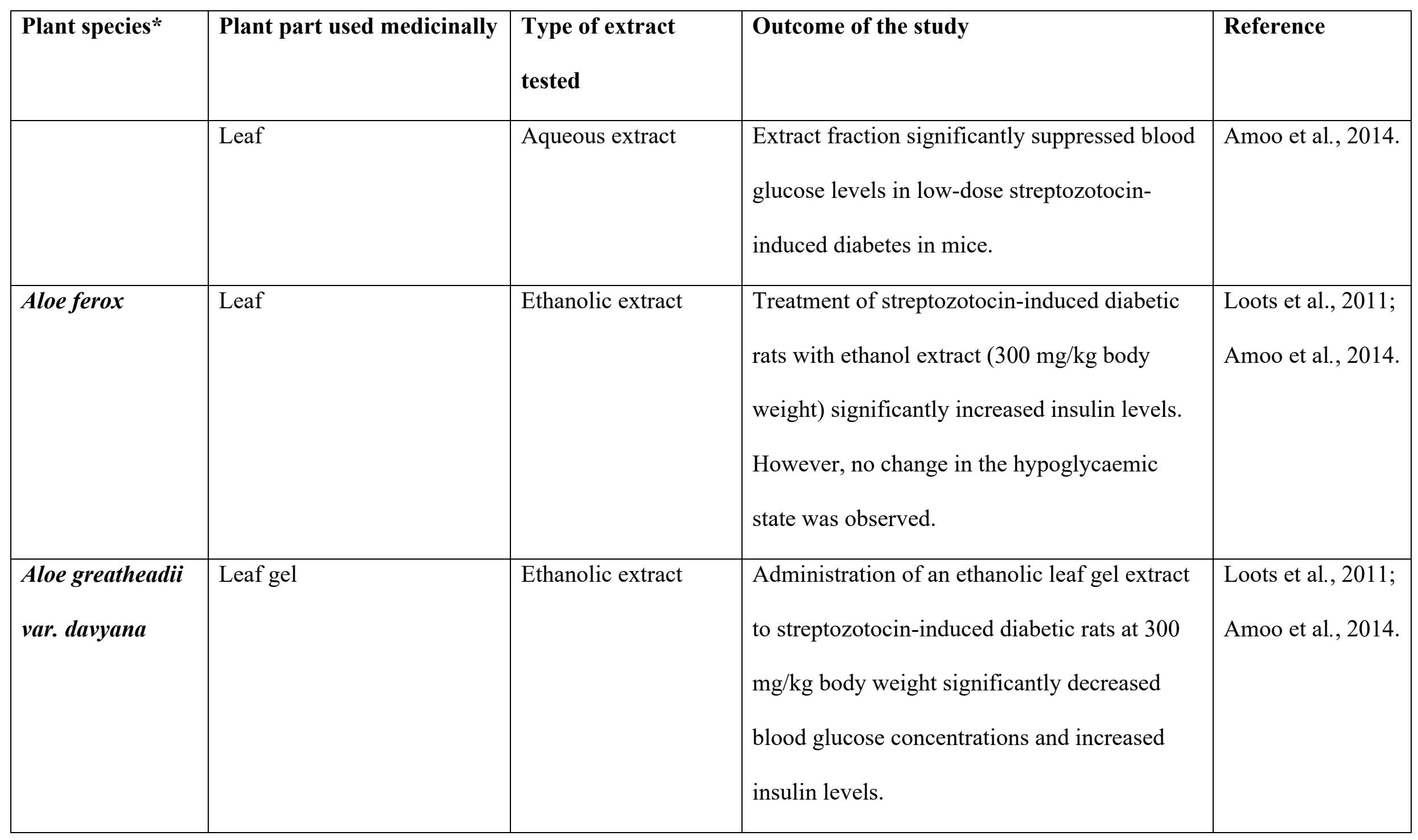




\begin{tabular}{|c|c|c|c|c|}
\hline Plant species* & Plant part used medicinally & $\begin{array}{l}\text { Type of extract } \\
\text { tested }\end{array}$ & Outcome of the study & Reference \\
\hline Artemisia afra & Leaves and isolated saponins & Aqueous extracts & $\begin{array}{l}\text { Aqueous extract significantly reduces blood } \\
\text { glucose concentrations in streptozotocin- } \\
\text { induced diabetic rats. A. afra saponins also } \\
\text { have hypoglycaemic effects in diabetic rabbits. }\end{array}$ & $\begin{array}{l}\text { Afolayan and } \\
\text { Sunmonu, 2011; } \\
\text { Afolayan and } \\
\text { Sunmonu, } 2013 .\end{array}$ \\
\hline
\end{tabular}




\begin{tabular}{|c|c|c|c|c|}
\hline Plant species* & Plant part used medicinally & $\begin{array}{l}\text { Type of extract } \\
\text { tested }\end{array}$ & Outcome of the study & Reference \\
\hline
\end{tabular}




\begin{tabular}{|c|c|c|c|c|}
\hline Plant species* & Plant part used medicinally & $\begin{array}{l}\text { Type of extract } \\
\text { tested }\end{array}$ & Outcome of the study & Reference \\
\hline $\begin{array}{l}\text { Brachylaena } \\
\text { elliptica }\end{array}$ & Leaves & Aqueous extract & $\begin{array}{l}\text { Crude extract decreasing blood glucose levels } \\
\text { in L6 myoblast cells. This suggested that } B \text {. } \\
\text { elliptica works in a similar manner to } \\
\text { metformin. An increase in the glucose uptake } \\
\text { was seen in HepG2 cells in a dose-dependent } \\
\text { manner. The plant extract was dosed at } 25 \text { and } \\
100 \mu \mathrm{g} / \mathrm{mL} \text {. }\end{array}$ & Sagbo et al., 2018. \\
\hline
\end{tabular}




\begin{tabular}{|c|c|c|c|c|}
\hline Plant species* & Plant part used medicinally & $\begin{array}{l}\text { Type of extract } \\
\text { tested }\end{array}$ & Outcome of the study & Reference \\
\hline $\begin{array}{l}\text { Carpobrotus } \\
\text { edulis }\end{array}$ & leaf & & $\begin{array}{l}\text { In vitro studies by measuring the alpha- } \\
\text { glucosidase inhibitory activity. Potential }\end{array}$ & $\begin{array}{l}\text { Mulaudzi et al., } \\
2019 .\end{array}$ \\
\hline
\end{tabular}




\begin{tabular}{|c|c|c|c|c|}
\hline Plant species* & Plant part used medicinally & $\begin{array}{l}\text { Type of extract } \\
\text { tested }\end{array}$ & Outcome of the study & Reference \\
\hline $\begin{array}{l}\text { Catha edulis } \\
\text { (Vahl) Endl. }\end{array}$ & Leaves, roots and stems & $\begin{array}{l}\text { Organic and aqueous } \\
\text { extracts }\end{array}$ & $\begin{array}{l}\text { Summary of the effect of plant extracts on } \\
\text { glucose utilisation and toxicity in Chang liver, } \\
\text { 3T3-L1 adipose and C2C12 muscle cells using } \\
\text { a scoring system demonstrates best activity for } \\
\text { organic leaf extract. }\end{array}$ & $\begin{array}{l}\text { Van de Venter et } \\
\text { al., } 2008 .\end{array}$ \\
\hline
\end{tabular}




\begin{tabular}{|c|c|c|c|c|}
\hline Plant species* & Plant part used medicinally & $\begin{array}{l}\text { Type of extract } \\
\text { tested }\end{array}$ & Outcome of the study & Reference \\
\hline $\begin{array}{l}\text { Chironia } \\
\text { baccifera }\end{array}$ & Whole plant & $\begin{array}{l}\text { Organic and aqueous } \\
\text { extracts }\end{array}$ & $\begin{array}{l}\text { The effect of plant extracts on glucose } \\
\text { utilisation and toxicity in Chang liver, 3T3-L1 } \\
\text { adipose and C2C12 muscle cells using a } \\
\text { scoring system demonstrated very good }\end{array}$ & $\begin{array}{l}\text { Van de Venter et } \\
\text { al., } 2008 .\end{array}$ \\
\hline
\end{tabular}




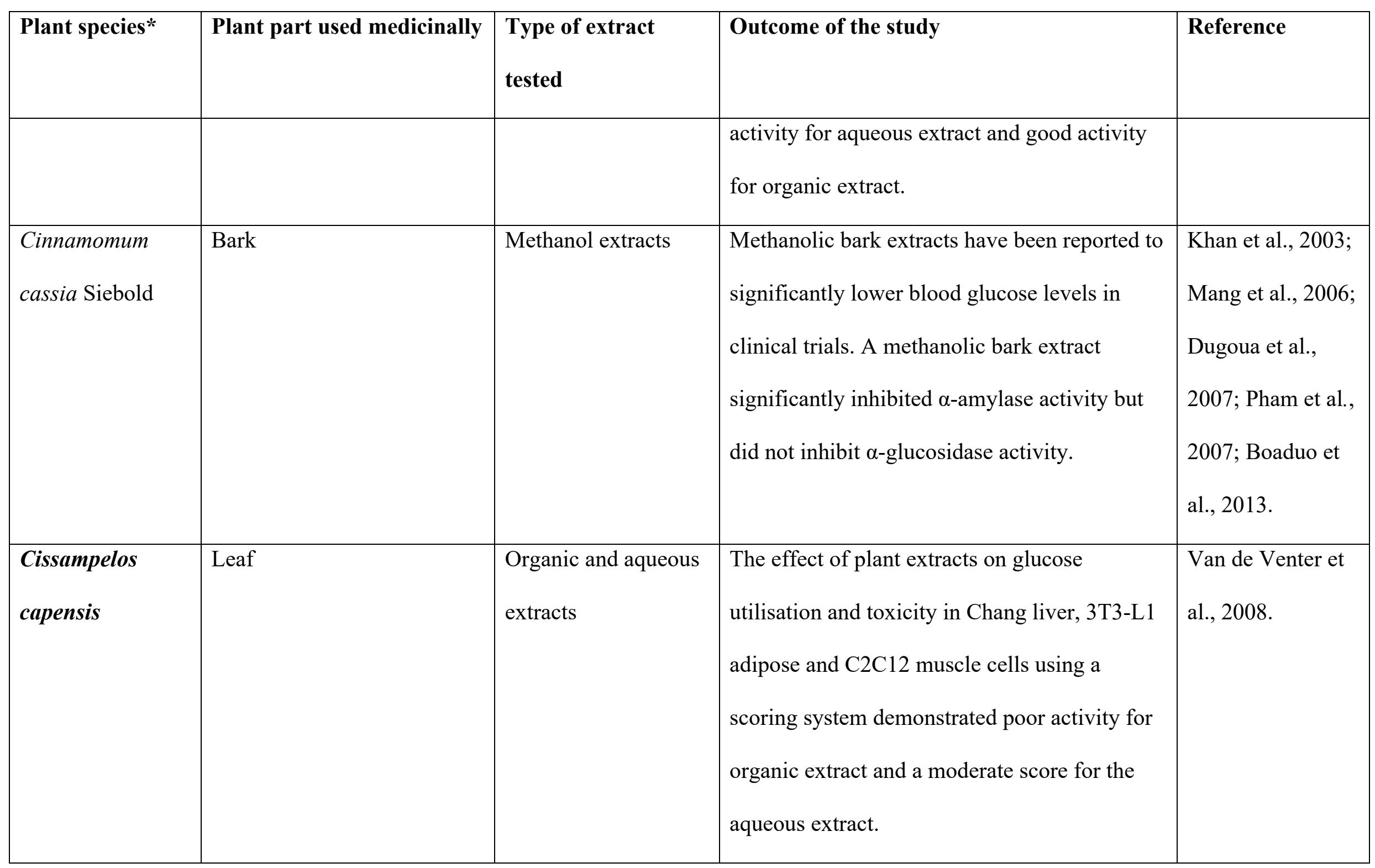




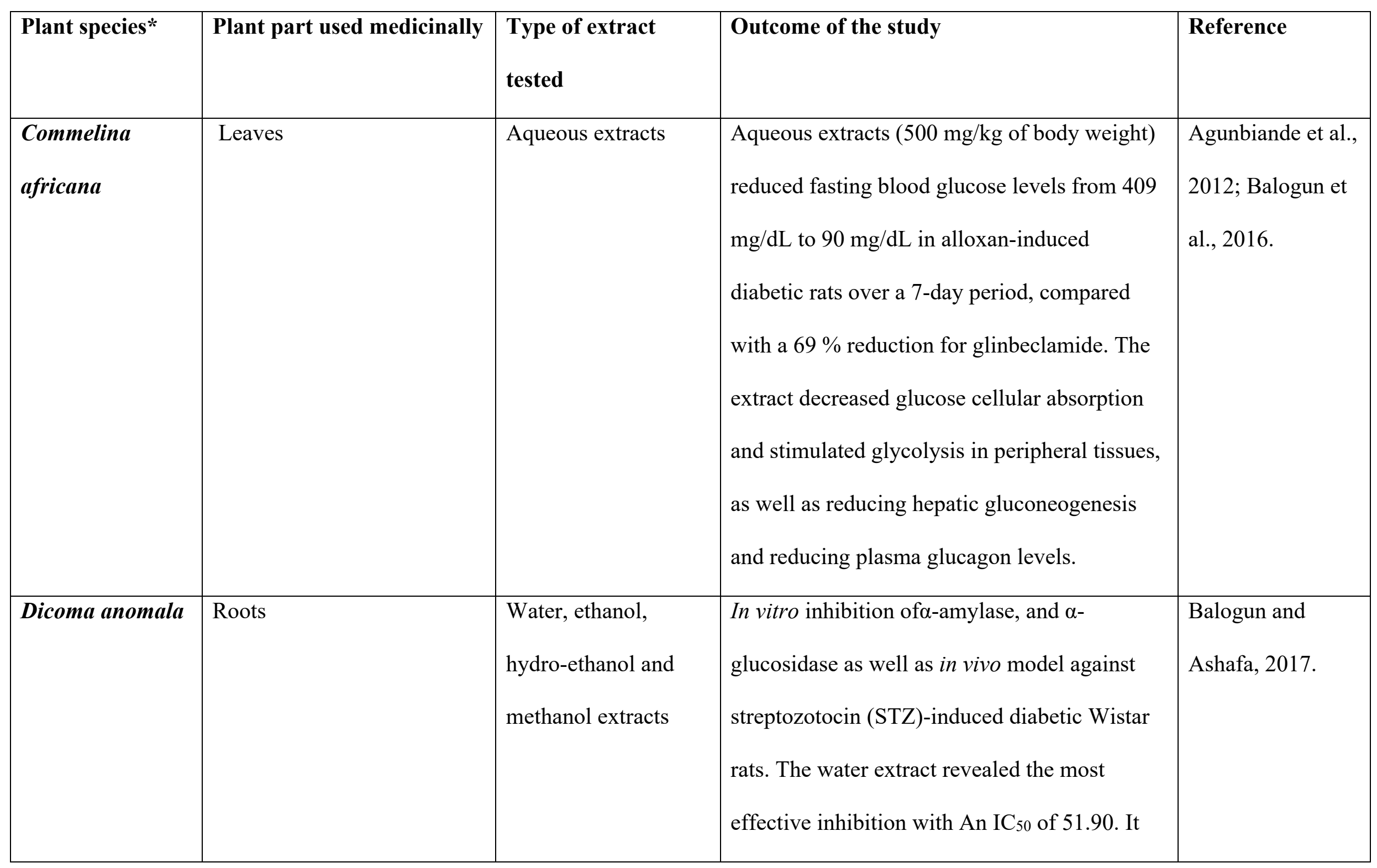




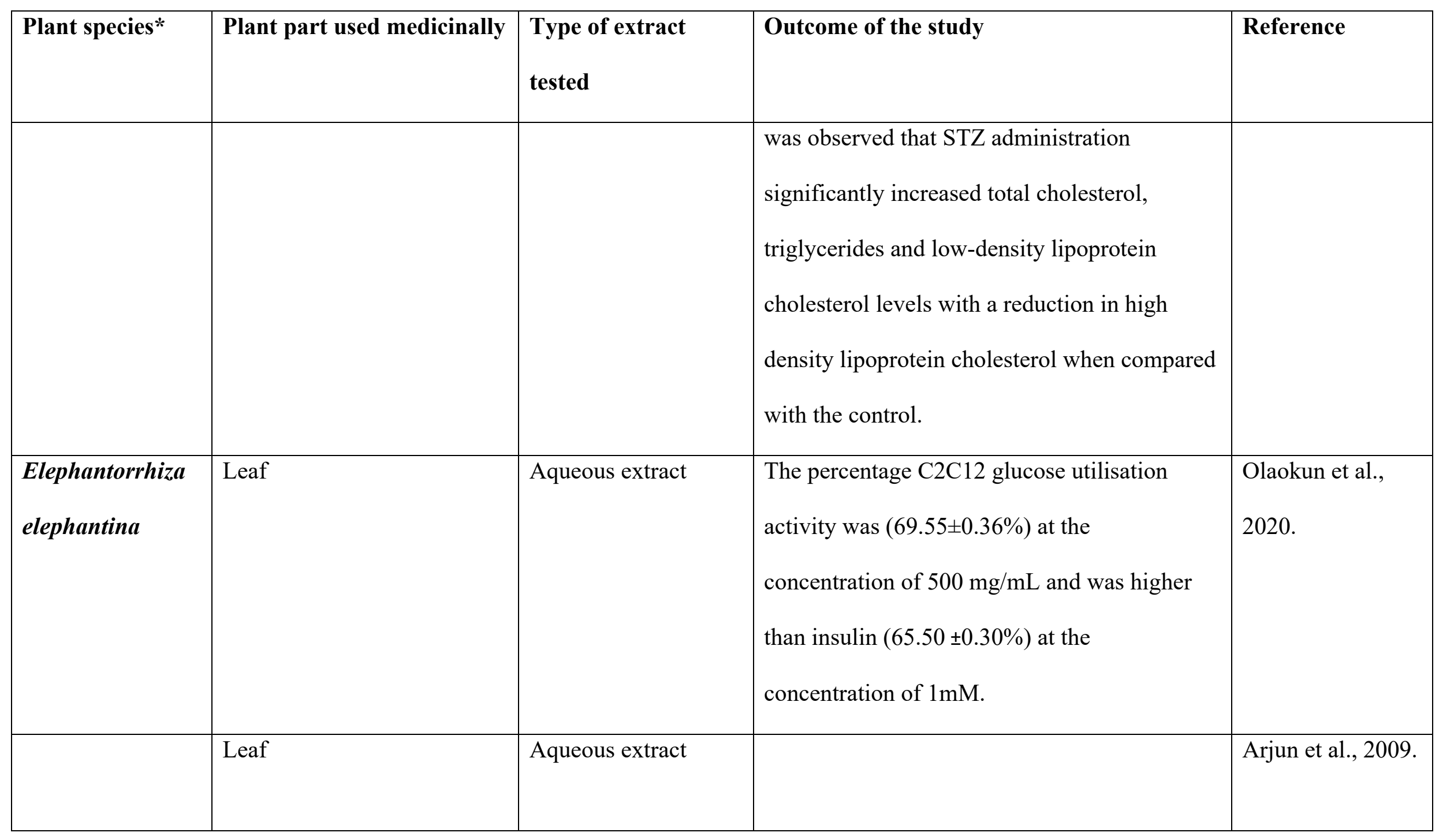




\begin{tabular}{|c|c|c|c|c|}
\hline Plant species* & Plant part used medicinally & $\begin{array}{l}\text { Type of extract } \\
\text { tested }\end{array}$ & Outcome of the study & Reference \\
\hline $\begin{array}{l}\text { Euclea undulata } \\
\text { var.myrtina }\end{array}$ & Root bark & Acetone extract & $\begin{array}{l}\text { Root bark at a concentration of } 100 \mathrm{mg} / \mathrm{kg} \\
\text { body weight lowered fasting blood glucose } \\
\text { levels as well as elevated cholesterol and } \\
\text { triglyceride levels to near normal without any } \\
\text { weight gain demonstrating antidiabetic activity } \\
\text { in type } 2 \text { induced diabetic rats. }\end{array}$ & $\begin{array}{l}\text { Deutschländer et } \\
\text { al., } 2012 \text {. }\end{array}$ \\
\hline $\begin{array}{l}\text { Gymnema } \\
\text { sylvestre }\end{array}$ & Leaf & Ethanolic extract & $\begin{array}{l}\text { Ethanolic leaf extract stimulated insulin release } \\
\text { from pancreatic } \beta \text {-cells. The extract also } \\
\text { decreased blood glucose concentrations in a } \\
\text { diabetic rat model. In a clinical study }\end{array}$ & $\begin{array}{l}\text { Baskaran et al., } \\
\text { 1990; Khan et al., } \\
\text { 2011. }\end{array}$ \\
\hline
\end{tabular}




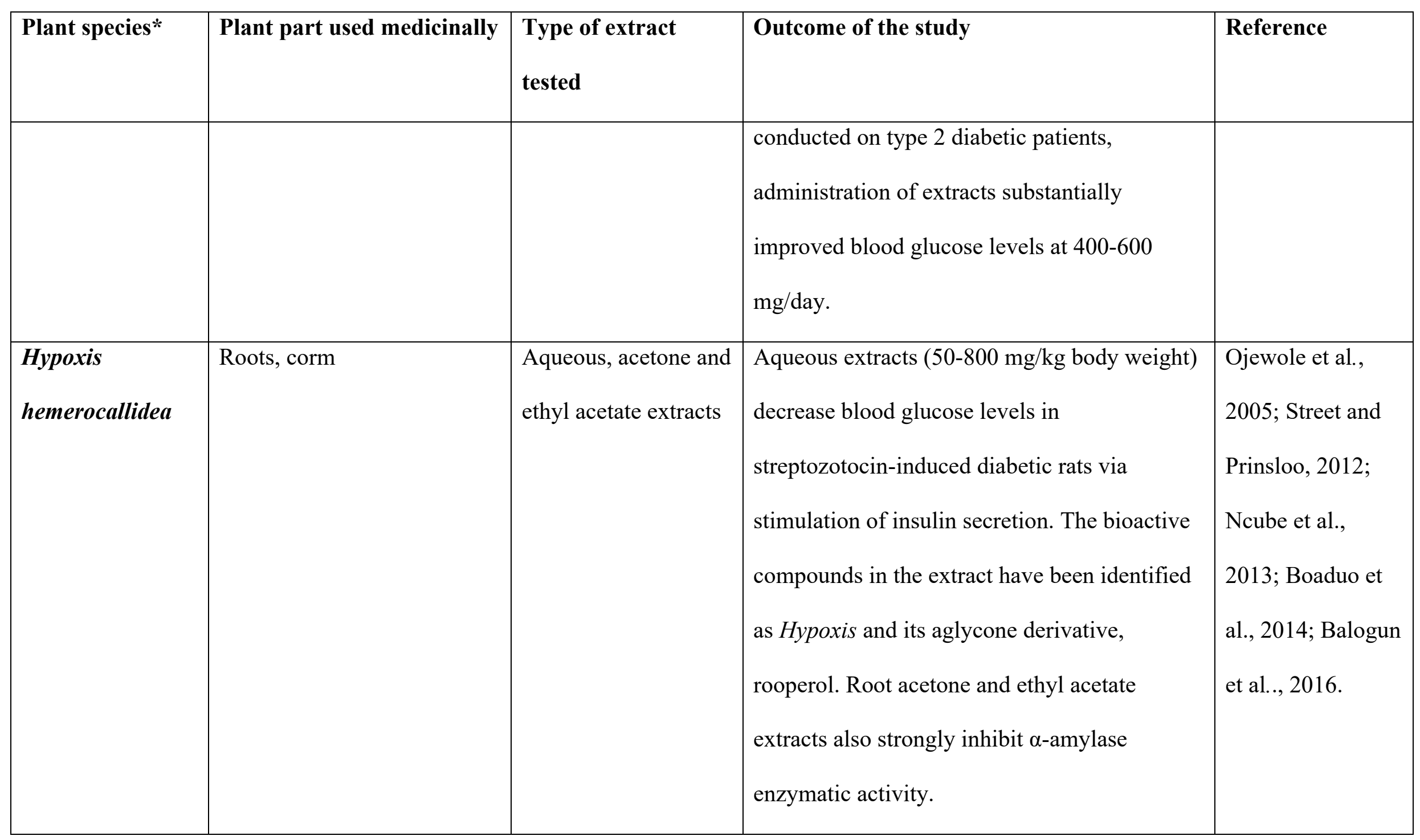




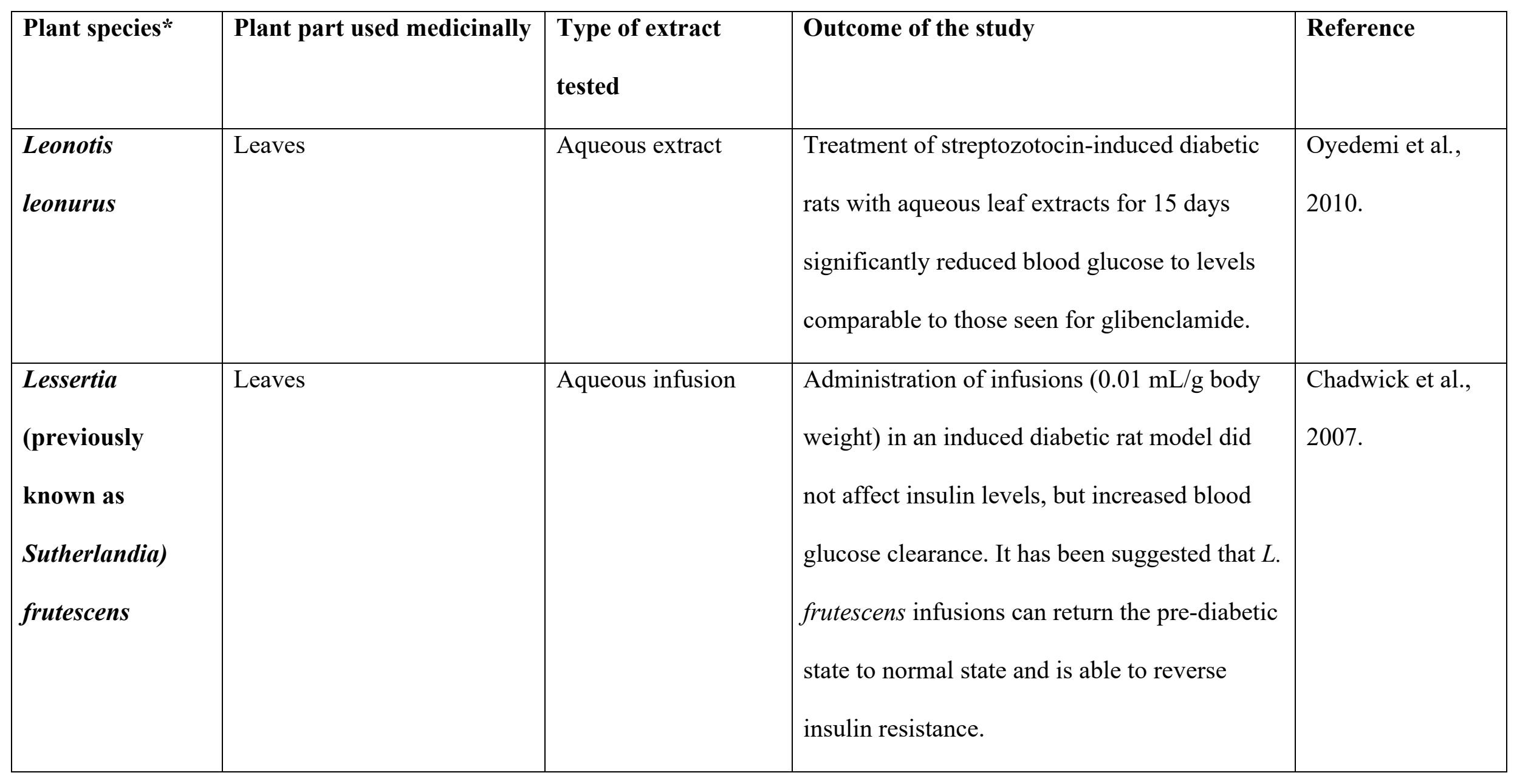




\begin{tabular}{|c|c|c|c|c|}
\hline Plant species* & Plant part used medicinally & $\begin{array}{l}\text { Type of extract } \\
\text { tested }\end{array}$ & Outcome of the study & Reference \\
\hline $\begin{array}{l}\text { Momordica } \\
\text { foetida }\end{array}$ & Fruit & Aqueous extract & $\begin{array}{l}\text { Administration of extracts decreased blood } \\
\text { glucose levels in normal rats but had no effects } \\
\text { in an alloxan-treated diabetic rat model. This } \\
\text { was attributed to the lack of synergistic } \\
\text { compounds found in the fruits. The effects of } \\
\text { plant extracts on glucose utilisation and } \\
\text { toxicity in Chang liver, 3T3-L1 adipose and } \\
\text { C2C12 muscle cells using a scoring system } \\
\text { indicated moderate to poor effects. }\end{array}$ & $\begin{array}{l}\text { Van de Venter et } \\
\text { al., 2008; } \\
\text { Afolayan and } \\
\text { Sunmonu, } 2010 .\end{array}$ \\
\hline
\end{tabular}




\begin{tabular}{|c|c|c|c|c|}
\hline Plant species* & Plant part used medicinally & $\begin{array}{l}\text { Type of extract } \\
\text { tested }\end{array}$ & Outcome of the study & Reference \\
\hline $\begin{array}{l}\text { Olea europaea } \\
\text { subsp. africana }\end{array}$ & Leaves & Aqueous extract & $\begin{array}{l}\text { Aqueous olive leaf extracts }(0.5 \mathrm{~g} / \mathrm{kg} \text { body } \\
\text { weight) significantly reduce serum glucose } \\
\text { concentrations towards normal values in a } \\
\text { streptozotocin-induced diabetic rat model. } \\
\text { Indeed, the antidiabetic effect of } O \text {. europa } \\
\text { extract was greater than that of glibenclamide. } \\
\text { Blood glucose levels were restored to the basal } \\
\text { level in } 13 \text { days. The decrease in blood glucose } \\
\text { levels was comparable to that of metformin. }\end{array}$ & $\begin{array}{l}\text { Eidi et al., 2008; } \\
\text { El and Karakaya } \\
\text { 2009; El Amin et } \\
\text { al. 2013; Hashmi } \\
\text { et al. } 2015 \text {. }\end{array}$ \\
\hline
\end{tabular}




\begin{tabular}{|c|c|c|c|c|}
\hline Plant species* & Plant part used medicinally & $\begin{array}{l}\text { Type of extract } \\
\text { tested }\end{array}$ & Outcome of the study & Reference \\
\hline $\begin{array}{l}\text { Opuntia ficus- } \\
\text { indica }\end{array}$ & Seed & Oil & $\begin{array}{l}\text { The administration of extract at a } \\
\text { concentration of } 2 \mathrm{ml} / \mathrm{kg} \text { attenuated alloxan- } \\
\text { induced death and hyperglycemia }(\mathrm{P}<0.001) \text { in } \\
\text { treated mice. It was postulated that the role of } \\
\text { synergism of anti-oxidant compounds in } \\
\text { quenching free radicals may have resulted in } \\
\text { the reduction of Allx-induced diabetes in mice. }\end{array}$ & $\begin{array}{l}\text { Berraaouan et al., } \\
2015 \text {. }\end{array}$ \\
\hline
\end{tabular}




\begin{tabular}{|l|l|l|l|l|}
\hline Plant species* & Plant part used medicinally & $\begin{array}{l}\text { Type of extract } \\
\text { tested }\end{array}$ & Outcome of the study & Reference \\
\hline $\begin{array}{l}\text { Ornithogalum } \\
\text { longibracteatum } \\
\text { Jacq. }\end{array}$ & Bulb & Aqueous and ethanol & The $\%$ glucose uptake for aqueous extracts was \\
& & & $\begin{array}{l}129.2 \mu \mathrm{g} / \mathrm{mL} \pm 4.19 \text { and for ethanol extracts } \\
\text { extracts }\end{array}$ & $\begin{array}{l}118.3 \mu \mathrm{g} / \mathrm{mL} \pm 5.26 . \text { The starting } \\
\text { concentration } \text { was } 0.5 \mu \mathrm{g} / \mathrm{mL} . \text { The insulin }\end{array}$ \\
& & & control at starting concentration of $1 \mu \mathrm{M}$ \\
& & & demonstrated activities $119.7 \mu \mathrm{g} / \mathrm{mL} \pm 1.46$ \\
\end{tabular}




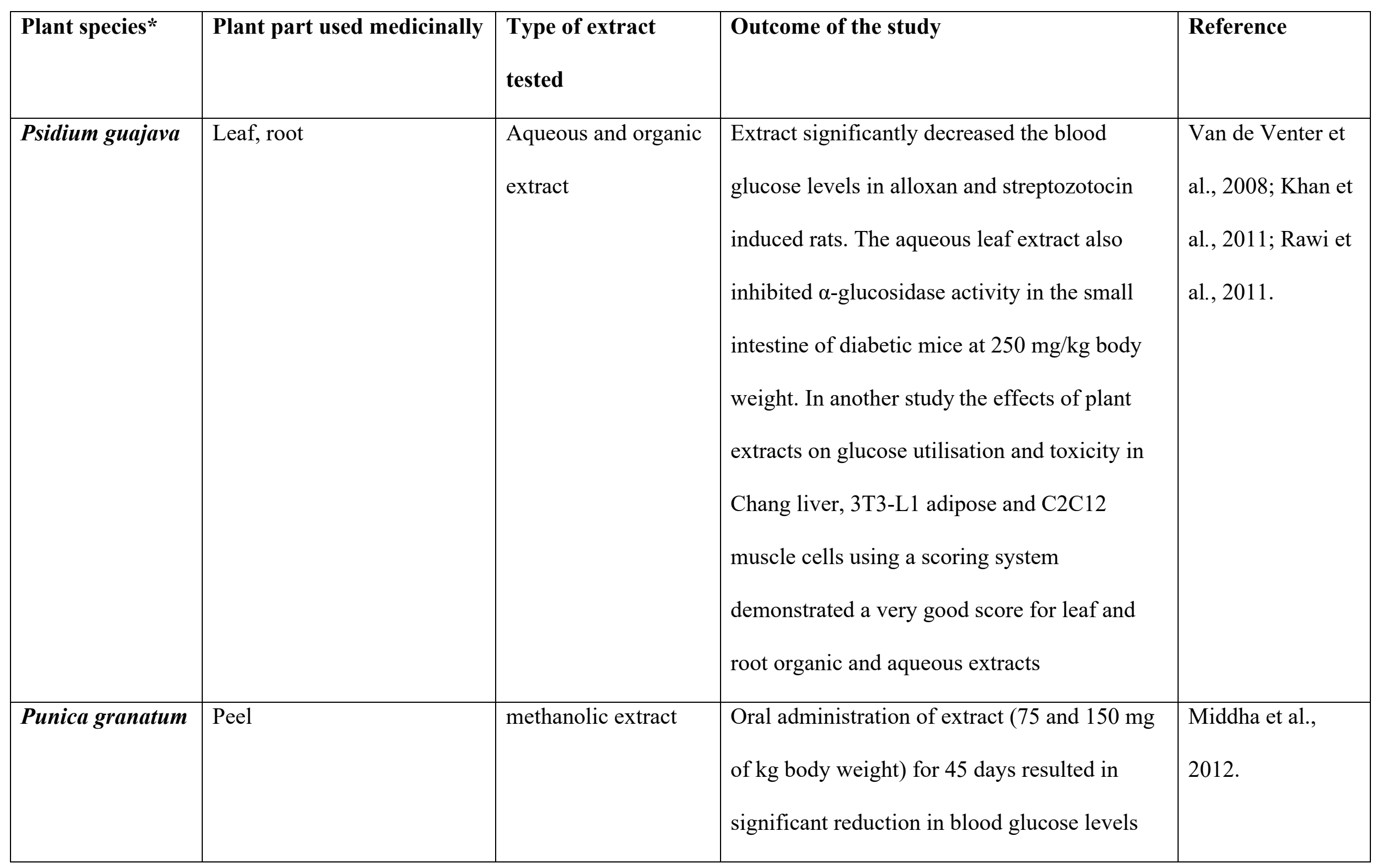




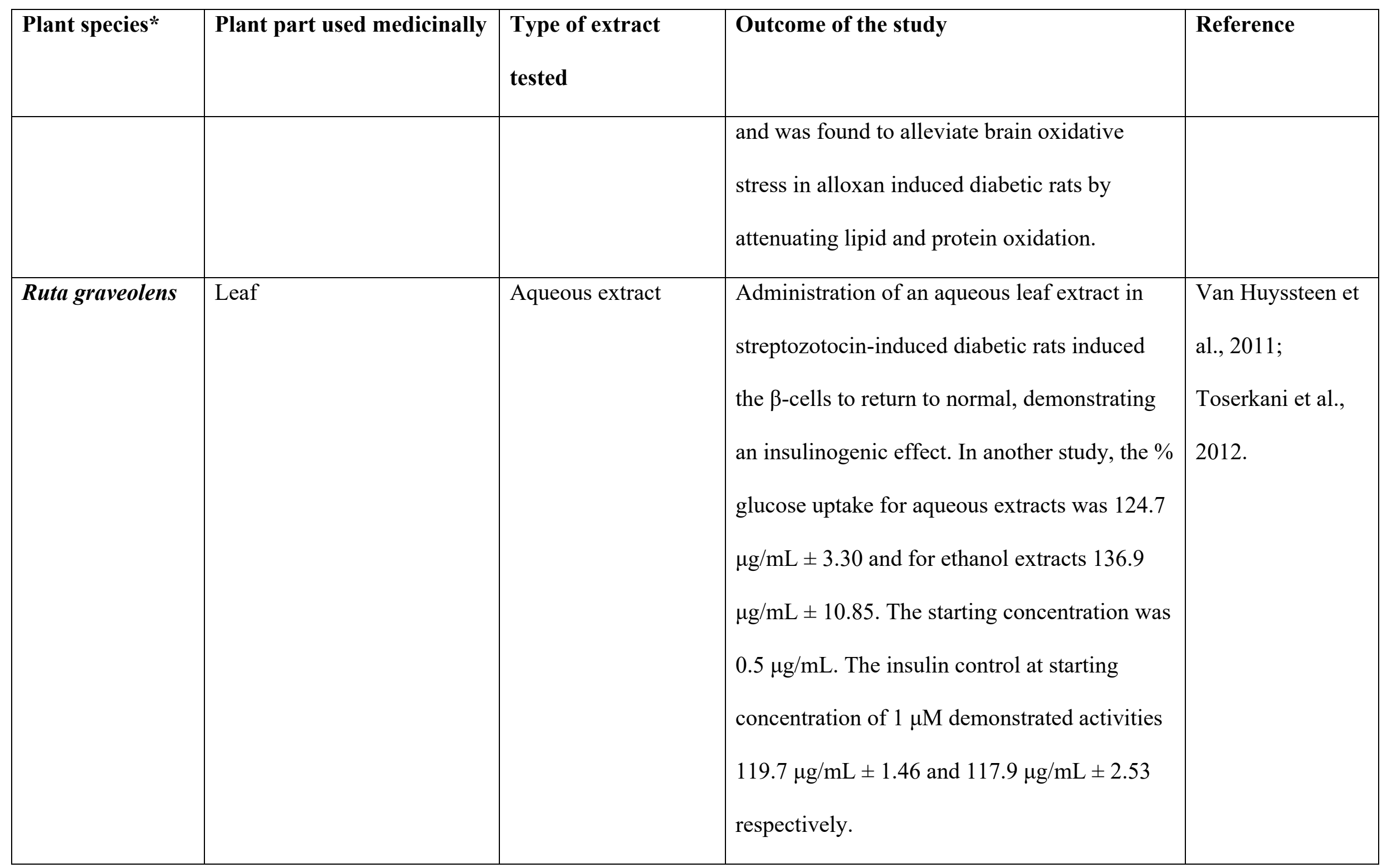




\begin{tabular}{|c|c|c|c|c|}
\hline Plant species* & Plant part used medicinally & $\begin{array}{l}\text { Type of extract } \\
\text { tested }\end{array}$ & Outcome of the study & Reference \\
\hline $\begin{array}{l}\text { Sclerocarya } \\
\text { birrea (A. Rich.) } \\
\text { Hochst. subsp. } \\
\text { caffra (Sond.) }\end{array}$ & Stem bark and root & $\begin{array}{l}\text { Organic and aqueous } \\
\text { extracts }\end{array}$ & $\begin{array}{l}\text { The effect of plant extracts on glucose } \\
\text { utilisation and toxicity in Chang liver, 3T3-L1 } \\
\text { adipose and } \mathrm{C} 2 \mathrm{C} 12 \text { muscle cells using a } \\
\text { scoring system indicated excellent activity for } \\
\text { stem and bark (organic extracts) followed by } \\
\text { good activity from the aqueous extracts. }\end{array}$ & $\begin{array}{l}\text { Van de Venter et } \\
\text { al., } 2008 .\end{array}$ \\
\hline
\end{tabular}




\begin{tabular}{|c|c|c|c|c|}
\hline Plant species* & Plant part used medicinally & $\begin{array}{l}\text { Type of extract } \\
\text { tested }\end{array}$ & Outcome of the study & Reference \\
\hline $\begin{array}{l}\text { Tarchonanthus } \\
\text { camphoratus L. }\end{array}$ & Leaves and soft twigs & $\begin{array}{l}\text { Aqueous and ethanol } \\
\text { extracts }\end{array}$ & $\begin{array}{l}\text { The } \% \text { glucose uptake for aqueous extracts was } \\
128.4 \mu \mathrm{g} / \mathrm{mL} \pm 3.27 \text { and for ethanol extracts } \\
131.6 \mu \mathrm{g} / \mathrm{mL} \pm 6.54 \text {. The starting } \\
\text { concentration was } 0.5 \mu \mathrm{g} / \mathrm{mL} \text {. The insulin }\end{array}$ & $\begin{array}{l}\text { Van Huyssteen et } \\
\text { al., } 2011 .\end{array}$ \\
\hline
\end{tabular}




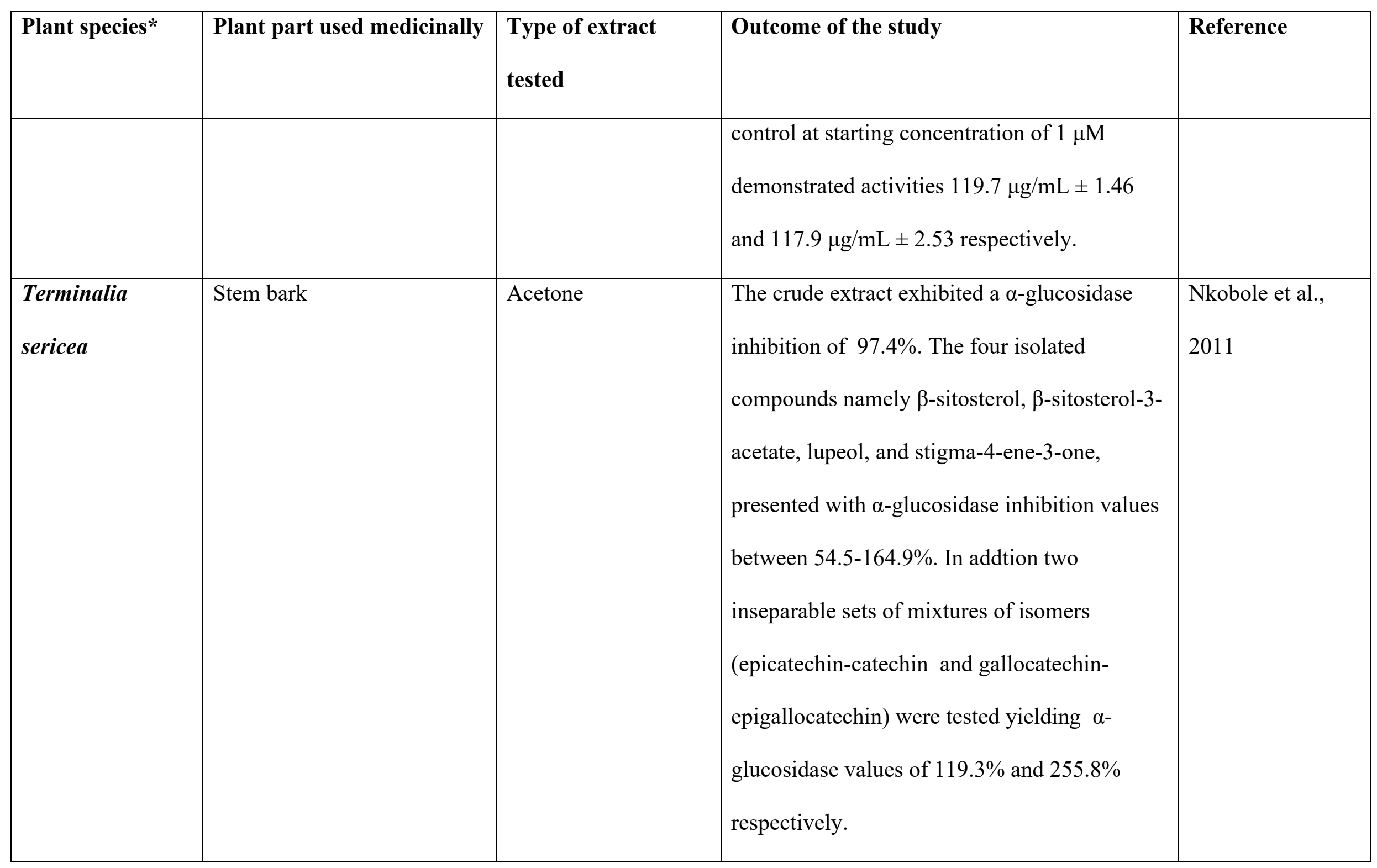




\begin{tabular}{|c|c|c|c|c|}
\hline Plant species* & Plant part used medicinally & $\begin{array}{l}\text { Type of extract } \\
\text { tested }\end{array}$ & Outcome of the study & Reference \\
\hline
\end{tabular}




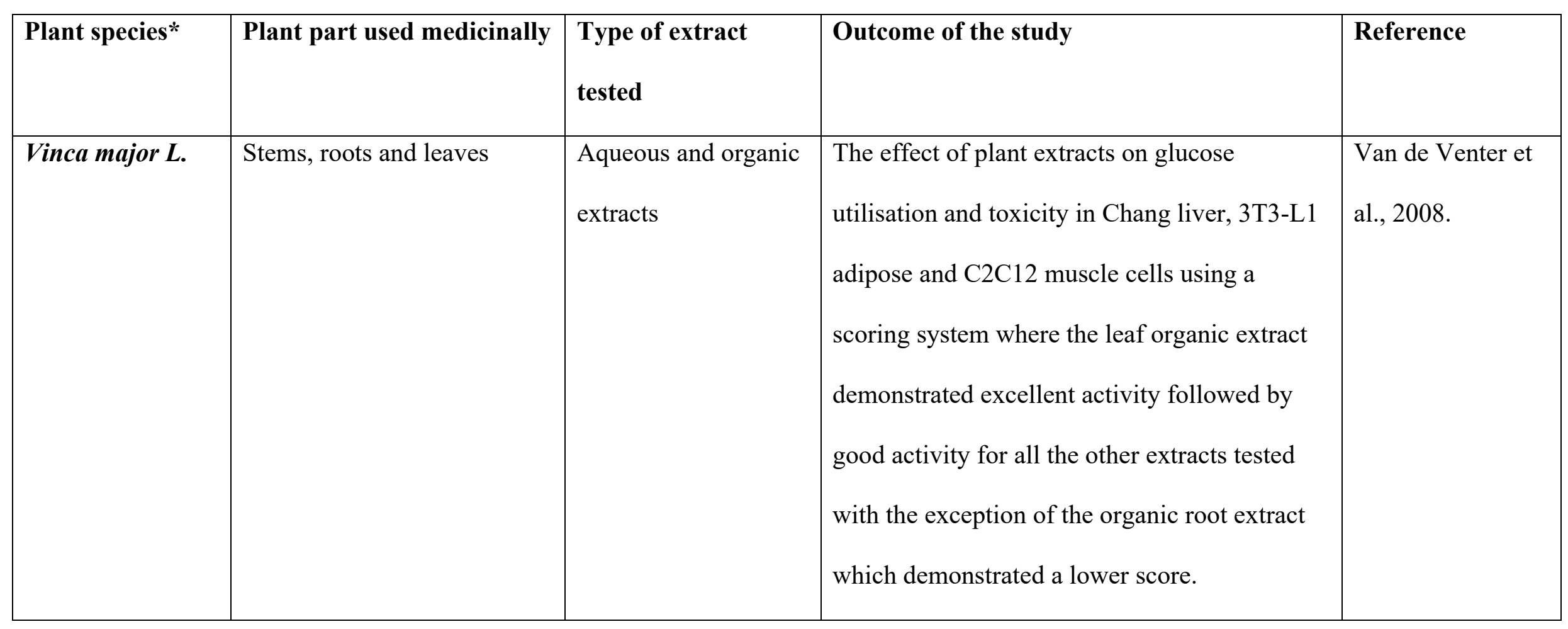


aqueous S. henningsii bark extract (Oyedemi et al 2012; Oyedemi et al 2013). The authors of those studies have suggested that the extract stimulates glucose uptake in the peripheral tissues, thereby lowering blood glucose concentrations. However, there are concerns with regards to the safety of $S$. henningsii in the treatment of diabetes due to toxicity, as well as antagonistic effects when used in combination with metformin and the plant should only be used with caution (Oyedemi et al 2012; Oyedemi et al 2013).

\section{Discussion}

An effective and targeted way to develop new drugs is through a re-examination of traditionally used medicinal plants for potent, non-toxic and cost-effective DM therapies. South Africa has one of the most diverse floras in the world, with more than 30,000 plant species documented. To date, the therapeutic uses have been recorded in the ethnobotanical literature for approximately 3000 of those species (Van Wyk et al., 1997). Fewer have been rigorously examined for therapeutic properties and only a small number have been tested for anti-DM related activities. However, it is encouraging that of the eight species (A. ferox, A. afra, D. anomala, M. balsamina, O. ficus-indica, P. prunelloides, L. frutescens subsp. frutescens, and E. punctulatus) that were the most frequently mentioned in Table 2 (traditional use), only two (P. prunelloides subsp. frutescens and E. punctulatus) have been neglected in follow-up validation studies. As far as the many other species used traditionally, much more research is required in this field to validate the traditional usage and to evaluate the mechanisms by which these plants work. Species selection for therapeutic screening is difficult as the ethnobotanical literature usually describes the usage of a plant species to lessen specific symptoms, rather than to treat a complex disease like DM. For example, many plants are recorded as being useful to 
decrease urinary output (a symptom of DM). However, increased urinary frequency and volume may also be a symptom of multiple other diseases including some urinary tract infections (UTIs) and prostatic hyperplasia (Upton 2013). Thus, it may not be possible to discern whether a plant was used specifically to treat DM or one of these pathologies. Where there was any doubt, the plant was excluded from our study. However, these other species may have anti-DM related activities and future studies should not neglect them. Another aspect worth noting is that when reviewing the ethnobotanical uses, the doses used were absent in almost all cases making correlation to toxicity difficult. Dosage is vitally important and future ethnobotanical reviews should include this during the survey process.

In this study, 137 plant species used traditionally for the treatment of diabetes were identified by a thorough literature search. Most of these plants are yet to be rigorously examined to validate their traditional use. Mechanistic detail has been determined for far fewer species. When efficacy studies were conducted, they have largely used the rat or rabbit model systems and (with some notable exceptions) the efficacy has not been established in humans. These in vivo models are convenient for the screening of new potential anti-DM therapies and they are relatively inexpensive and reproducible. However, they are often not the most relevant model to evaluate potential new DM therapies. To evaluate a potential DM therapy in these experimental animals, DM is induced with a chemical inducer. Alloxan or streptozotocin are most frequently used for this purpose. Both of these compounds are relevant for examining type $1 \mathrm{DM}$ only and are not relevant to study the effects in type $2 \mathrm{DM}$. Alloxan treatment induces pancreatic $\beta$-cell death (as also occurs in type $1 \mathrm{DM}$ ), resulting in a substantially lower levels of secreted insulin and a corresponding increase in blood glucose levels (Singh and Pathak, 2015; Karthrikeyan and Islam, 2016). Streptozotocin treatment also substantially reduces insulin secretion, resulting in hyperglycaemia. Both of these treatments therefore induce an insulin sensitive form of DM. It is estimated that the insulin sensitive form of the 
disease (type $1 \mathrm{DM}$ ) currently accounts for only approximately $10 \%$ of the cases of DM in Western countries (American Diabetes Association, 2010). Notably, type 1 DM may already be effectively treated with intravenous insulin therapy.

In contrast, the insulin insensitive form of DM (type $2 \mathrm{DM}$ ) has relatively few and less effective treatments available. Metformin and SGLT2 inhibitors are the most frequently used chemotherapeutic options for the maintenance of blood glucose levels in individuals with type 2 DM (Mudaliar and Henry, 2001; Klein et al., 2004; Chao and Henry, 2010). However, these drugs are only generally effective in the early stages of the disease and lose efficacy as the disease progresses (American Diabetes Association, 2010). Furthermore, both classes of drugs have considerable toxicity and are associated with unwanted side effects. New therapies targeting type $2 \mathrm{DM}$ pathways are urgently required. Furthermore, the prevalence of type 2 $\mathrm{DM}$ is increasing more rapidly globally than all other forms of the disease combined (WHO, 2019). Some studies have induced insulin sensitivity in laboratory animals by mid to long-term dietary modification. Whilst, this is a substantially better model for testing the efficacy of potential new therapies against type $2 \mathrm{DM}$, it generally more closely corresponds with the prediabetic state than with full type $2 \mathrm{DM}$ and more relevant test models are required.

Several studies have also directly tested extracts and pure compounds against cultured cells in vitro. These methods have the advantage of being higher throughput and substantially less expensive than in vivo studies. The usage of standardised cell lines also results in greater reproducibility when similar studies are performed by different groups and it therefore allows for better comparisons between studies. Furthermore, cell culture studies are more relevant to type $2 \mathrm{DM}$. By testing a potential therapy against non-pancreatic cells, the effects of the drug on pancreatic insulin secretion are effectively negated. Glucose uptake into the cell must be via other pathways. Additionally, cell line studies are more suitable for mechanistic evaluations of the test therapy. However, whilst cell line studies have considerable advantages compared with 
in vivo assays, they are best considered as an intermediate step in the discovery of new type 2 DM therapeutics. The pharmacodynamic and pharmacokinetic properties of the therapy must also be considered. Thus, when a drug candidate is highlighted by these assays, substantial further research is needed to test the rate of absorption through the gut lumen, the clearance rate, interaction with other systems etc.

To be useful in the treatment of DM, an extract (or purified compound) must have a relatively low toxicity. This is particularly true for DM as the treatment regimens comprises of ongoing therapy. Notably, few of the studies screening the South African traditional medicine to treat DM also evaluated the toxicity of the extracts. In many cases, the highlighted plant species have multiple therapeutic uses and their toxicity has been evaluated in other studies. However, it is imperative that toxicity be evaluated parallel with anti-DM studies to provide an indication of the therapeutic index. Even if a plant extract is a potent antihyperglycemic agent, its therapeutic potential may be limited if it is also toxic to the host. Variability in the preparation and composition of extracts between studies also makes it difficult to link toxicology and activity results across multiple studies. Furthermore, several different efficacy and toxicity methodologies may be used in different studies, making comparisons difficult.

Additionally, selecting the most appropriate extraction technique is also important in evaluating a potential new therapy. Decoctions and infusions are generally the most common preparation methods in traditional medicine. Aqueous extracts are limited to extracting relatively high polarity compounds and often lack mid-low polarity compounds. This is desirable under Lipinski's rules of 5 (Lipinski, 2004) as mid-highly polar compounds have greater bioavailability. However, limiting investigations to aqueous extracts may overlook promising lower polarity compounds.

\section{Conclusion}


In conclusion, the ethnobotanical records of the use of South African plants to treat DM are relatively well documented, yet the follow-up validation studies have been neglected. Approximately only $31 \%$ of the plant species mentioned as a traditional means to treat or control blood sugar (Table 2) have been scientifically validated (Table 3) and further mechanisms of action of many of the identified plant species remain poorly examined. Furthermore, examining plant compounds, could yield important leads for therapy. A recent innovative approach to exploring anti-DM compounds from African medicinal plants using a DIA-DB Inverse Virtual Screening Web Server yielded 28 compounds with favorable anti-DM properties and this could be further extrapolated in the South African context of medicinal plant use for diabetes (Pereira et al., 2019). It is important to note that diabetes is a lifestyle disease and treatment is usually lifelong. Finding a natural alternative is extremely favourable and the quest to find a non-toxic effective supplement may provide great value, given the increasing epidemiology statistics especially in South Africa.

\section{Acknowledgements}

The authors are thankful for the support provided by the Department of Pharmacy and Pharmacology, University of the Witwatersrand, South Africa and by the Environmental Futures Research Institute, Griffith University, Australia. 


\section{References}

Abdul-Ghani, M.A., Norton, L., DeFronzo, R.A., 2012. Efficacy and safety of SGLT2 inhibitors in the treatment of type 2 diabetes mellitus. Curr. Diab. Rep. 12(3), 230-238.

Abo, K.A., Fred-Jaiyesimi, A.A., Jaiyesimi, A.E., 2008. Ethnobotanical studies of medicinal plants used in the management of diabetes mellitus in South Western Nigeria. J. Ethnopharmacol. 115(1), 67-71.

Adeniji, K.O., Amusan, O.O.G., Dlamini, P.S., Enow-Orock, E.G., Gamedze, S.T., Gbile, Z.O., Langa, A.D., Makhubu, L.P., Mahunnah, R.L.A., Mshana, R.N., Sofowora, A., Vilane, M.J., 2001. Traditional medicine and pharmacopoeia contribution to ethobotanical and floristic studies in Swaziland. OAU/STRC, Lagos.

Afolayan, A.J., Mbaebie, B.O., 2010. Ethnobotanical study of medicinal plants used as antiobesity remedies in Nkonkobe Municipality of South Africa. Pharmacogn. J. 2(11), $368-373$.

Afolayan, A.J., Sunmonu, T.O., 2010. In vivo studies on antidiabetic plants used in South African herbal medicine. J. Clin. Biochem. Nutr. 47(2), 98-106.

Afolayan, A.J., Sunmonu, T.O., 2011. Artemisia afra Jacq. ameliorates oxidative stress in the pancreas of streptozotocin-induced diabetic Wistar rats. 75 (11), 2083-2086.

Afolayan, A.J., Sunmonu, T.O., 2013. Protective role of Artemisia afra aqueous extract on tissue antioxidant defense systems in streptozotocin-induced diabetic rats. Afr. J. Tradit. Complement. Altern. Med. 10 (1),15-20. 
Afolayan, A.O., Adebusoyeb, L.A., Cadmusb, E.O., Ayeni, F.A., 2020. Insights into the gut microbiota of Nigerian elderly with type 2 diabetes and non-diabetic elderly persons. Heliyon 6(5), Article e03971.

Agunbiande, O. S., Ojezele, O. M., Ojezele, J. O., and Ajayi, A. Y. 2012. Hypoglycaemic activity of Commelina africana and Ageratum conyzoides in relation to their mineral composition. Afr. Health Sci. 12(2), 198-203.

Ahangarpour, A., Mohammadian, M., Dianat, M., 2012. Antidiabetic effect of hydroalcholic Urtica dioica leaf extract in male rats with fructose-induced insulin resistance. Iran J. Med. Sci., 37(3), 181-186.

Ahmad, M., Qureshi, R., Arshad, M., Khan, M.A., Zafar, M., 2009. Traditional herbal remedies used for the treatment of diabetes from district Attock (Pakistan). Pak. J. Bot. 41(6), $2777-2782$.

Al-Azzawie, H.F., Alhamdani, M.S., 2006. Hypoglycemic and antioxidant effect of oleuropein in alloxan-diabetic rabbits. Life Sci. 78(12), 1371-1377.

American Diabetes Association, 2010. Diagnosis and Classification of Diabetes Mellitus. Diabetes $\quad$ Care, 33(Suppl 1), S62. Accessed from https://care.diabetesjournals.org/content/33/Supplement_1/S62. Accessed 18 April 2020.

Amoo, S.O., Aremu, A.O., Van Staden, J. 2014. Unraveling the medicinal potential of South African Aloe species. J. Ethnopharmacol. 153, 19-41.

Apaya, M.K., Kuoa, T-F., Yang, M-T, Yang G., Hsiaoe, C-L., Chang, S-B., Ling, Y., Yang, W-C., 2020. Phytochemicals as modulators of $\beta$-cells and immunity for the therapy of type 1 diabetes: Recent discoveries in pharmacological mechanisms and clinical potential. Pharmacol. Res. 156, 104754. doi.org/10.1016/j.phrs.2020.104754 
Arjun P., Shivesh J., Sahu A.N., 2009. Antidiabetic activity of aqueous extract of Eucalyptus citriodora Hook. in alloxan induced diabetic rats. Pharmacogn. Mag. 5, 51-54.

Bailey, C.J., Day, C., 1989. Traditional plant medicines as treatments for diabetes. Diabetes Care 12(8), 553-564.

Bailey, C.J., Turner, R.C., 1996. Metformin. N. Engl. J. Med. 334(9), 574-579.

Baldissera, G., Sperotto, N.D., Rosa, H.T., Henn, J.G., Peres, V.F., Moura, D.J., Roehrs, R., Denardin, E.L., Dal Lago, P., Nunes, R.B., Saffi, J., 2016. Effects of crude hydroalcoholic extract of Syzygium cumini (L.) Skeels leaves and continuous aerobic training in rats with diabetes induced by a high-fat diet and low doses of streptozotocin. J. Ethnopharmacol. 194, 1012-1021.

Balogun, F.O., Tshabalala, N.T., Ashafa, A.O.T. 2016. Antidiabetic medicinal plants used by the Basotho tribe of Eastern Free State: A review. J. Diabetes Res. doi: $10.1155 / 2016 / 4602820$.

Balogun, F.O., Ashafa, A.O.T., 2017. Aqueous root extracts of Dicoma anomala (Sond.) extenuates postprandial hyperglycaemia in vitro and its modulation on the activities of carbohydrate-metabolizing enzymes in streptozotocin-induced diabetic Wistar rats. S. Afr. J. Bot. 112, 112-111.

Baskaran K, Kizar Ahamath B, Radha Shanmugasundaram K, Shanmugasundaram E.R., 1990. Antidiabetic effect of a leaf extracts from Gymnema sylvestre in non-insulin-dependent diabetes mellitus patients. J. Ethnopharmacol. 30, 295-300.

Berraaouan, A., Abderrahim, Z., Hassane, M., Abdelkhaleq, L., Mohammed, A., Mohamed, B., 2015. Evaluation of protective effect of cactus pear seed oil (Opuntia ficus-indica 
L. MILL.) against alloxan-induced diabetes in mice. Asian Pac. J. Trop. Med. 8(7), $532-537$.

Bertram MY, Jaswal AV, Van Wyk VP, Levitt, N.S., Hofman, K.J., 2013. The non-fatal disease burden caused by type 2 diabetes in South Africa. Glob. Health Action, 6,19244. doi: 10.3402/gha.v6i0.19244.

Bnouham, M., Merhfour, F.Z., Ziyyat, A., Mekhfi, H., Aziz, M., Legssyer, A., 2003. Antihyperglycemic activity of the aqueous extract of Urtica dioica. Fitoterapia 74(78), 677-681.

Boaduo, N.K.K., Katerere, D., Eloff, J.N., Naidoo, V., 2014. Evaluation of six plant species used traditionally in the treatment and control of diabetes mellitus in South Africa using in vitro methods. Pharm. Biol. 52(6), 756-761.

Bradshaw D, Norman R, Pieterse D, Levitt N.S., 2007. Estimating the burden of disease attributable to diabetes in South Africa in 2000. South Afr. Med. J., 97, 700-706.

Chauke, M.A., Shai, L.J., Mogale, M.A., Tshisikhawe, M.P., Mokgotho, M.P., 2015. Medicinal palnt use of villagers in the Mopani District, Limpopo Province, South Africa. Afr J Tradit Complement Altern Med. 12(3), 9-26.

Chacko, K.M., Bauer, T.A., Dale, R.A., Dixon, J.A., Schrier, R.W., Estacio, R.O., 2008. Heart rate recovery predicts mortality and cardiovascular events in patients with type 2 diabetes. Med. Sci. Sports Exer. 40(2), 288-295.

Chadwick, W.A., Roux, S., Van de Venter, M., Louw, J., Oelofsen, W., 2007. Anti-diabetic effects of Sutherlandia frutescens in Wistar rats fed a diabetogenic diet. J. Ethnopharmacol. 109(1), 121-127.

Chinsembu, K.C., 2019. Diabetes mellitus and nature's pharmacy of putative antidiabetic plants. J. Herb. Med. 15, 100230. doi.org/10.1016/j.hermed.2018.09.001 
Chao, E.C., Henry, R.R., 2010. SGLT2 inhibition - a novel strategy for diabetes treatment. Nat. Rev. Drug Discov. 9(7), 551-559.

Chukwuma, C.I., Matsabisa, M.G., Ibrahim, M.A., Erukainure, O.L., Chabalala, M.H., 2019. Medicinal plants with concomitant anti-diabetic and anti-hypertensive effects as potential sources of dual acting therapies against diabetes and hypertension: A review. J. Ethnopharmacol. 235, 329-360.

Cock, I.E., 2015a. The genus Aloe: Phytochemistry and therapeutic uses including treatments for gastrointestinal conditions and chronic inflammation. In Novel Natural Products: Therapeutic Effects in Pain, Arthritis and Gastro-intestinal Diseases, 179-235, Springer, Basel.

Cock, I.E., 2015b. The medicinal properties and phytochemistry of plants of the genus Terminalia (Combretaceae). Inflammopharmacol. 23, 203-229.

Cock, I.E., Selesho, M.I., Van Vuuren, S.F., 2018a. A review of the traditional use of Southern African medicinal plants for the treatment of selected parasite infections affecting humans. J. Ethnopharmacol. 220, 250-264.

Cock, I.E., Cheesman, M.J., 2018b. Plants of the genus Syzygium (Myttaceae): A review on the ethnobotany, medicinal properties and phytochemistry. In Bioactive Compounds of Medicial Plants. Properties and Potential for Human Health, Editors Goyal MR, Ayeleso AO, Apple Academic Press, NJ, USA.

Cock, I.E., Cheesman, M.J., 2019. The potential of plants of the genus Syzygium (Myrtaceae) for the prevention and treatment of arthritic and autoimmune diseases. In Bioactive Food as Dietary Interventions for Arthritis and Related Inflammatory Diseases, 2nd Edition, Elsevier Academic Press.

Corrigan, B.M., Van Wyk, B.E., Geldenhuys, C.J., Jardine, J.M., 2011. Ethnobotanical plant uses in the KwaNibela Peninsula, St Lucia, South Africa. S. Afr. J. Bot. 77, 346-359. 
Cunningham, A.B., 1988. An Investigation of the Herbal Medicine Trade in Natal/Kwazulu (No. 29). Institute of Natural Resources, University of Natal. South Africa

Dabelea, D., Crume, T., 2011. Maternal environment and the transgenerational cycle of obesity and diabetes. Diabetes 60(7), 1849-1855.

Dar, S.A., Ganai, F.A., Yousuf, A.R., Balkhi, M., Bhat, T.M., Sharma, P., 2013. Pharmacological and toxicological evaluation of Urtica dioica. Pharm. Biol. 51(2), $170-180$.

Davids, D., Gibson, D. and Johnson, Q., 2016. Ethnobotanical survey of medicinal plants used to manage high blood pressure and type 2 diabetes mellitus in Bitterfontein, Western Cape Province, South Africa. J. Ethnopharmacol. 194, 755-766.

De Beer, J.J., Van Wyk, B.E., 2011. An ethnobotanical survey of the Agter-Hantam, Northern Cape Province, South Africa. S. Afr. J. Bot. 77(3), 741-754.

Deutschländer, M.S., Van de Venter, M., Roux, S., Louw, J., Lall, N., 2009. Hypoglycaemic activity of four plant extracts traditionally used in South Africa for diabetes. J. Ethnopharmacol., 124(3), 619-624.

Deutschländer, M.S., Lall, N., Van de Venter, M., Dewanjee, S., 2012. The hypoglycemic activity of Euclea undulata Thunb. var. myrtina (Ebenaceae) root bark evaluated in a streptozotocin-nicotinamide induced type 2 diabetes rat model. S. Afr. J. Bot. 80, 9-12.

Dugoua, J., Seely, D., Perri, D., Cooley, K., Forelli, T., Mills, E., Koren, G., 2007. From type 2 diabetes to antioxidant activity: a systematic review of the safety and efficacy of common and cassia cinnamon bark. Canadian J. Physiol. Pharmacol. 85, 837847.

Durmuşkahya, C., Öztürk, M., 2013. Ethnobotanical survey of medicinal plants used for the treatment of diabetes in Manisa, Turkey. Sains Malays. 42(10), 1431-1438.

Eidi, A., Eidi, M., Darzi, R., 2008. Antidiabetic effect of Olea europaea L. in normal and diabetic rats. Phytother. Res. 23, 347-350. 
El Amin, M., Virk, P., Elobeid, M.A.R., Almarhoon, Z.M., Hassan, Z.K., Omer, S.A., Merghani, N.M., Daghestani, M.H., and Al Olayan, E.M., 2013. Anti-diabetic effect of Murraya koenigii (L) and Olea europaea (L) leaf extracts on streptozotocin induced diabetic rats. Pakistan J. Pharm. Sci. 26(2), 359-365.

El, S.N., Karakaya, S., 2009. Olive tree (Olea europaea) leaves: potential beneficial effects on human health. Nutrition Rev. 67(11), 632-638.

El-Demerdash, F.M., Yousef, M.I., El-Naga, N.I.A., 2005. Biochemical study on the hypoglycemic effects of onion and garlic in alloxan-induced diabetic rats. Food Chem. Toxicol. 43, 57-63.

El Haouari, M., Rosado, J.A., 2019. Phytochemical, anti-diabetic and cardiovascular properties of Urtica dioica L.(Urticaceae): A review. Mini Rev. Med. Chem. 19(1), 63-71.

El-Soud, N.A., Khalil, M., 2010. Antioxidative effects of Allium cepa essential oil in streptozotocin induced diabetic rats. Maced. J. Med. Sci. 3(4), 344-351.

Ezuruike, U.F., Prieto, J.M., 2020. The use of plants in the traditional management of diabetes in Nigeria: Pharmacological and toxicological considerations. J. Ethnopharmacol. In press.

Erasto, P., Adebola, P.O., Grierson, D.S., Afolayan, A.J., 2005. An ethnobotanical study of plants used for the treatment of diabetes in the Eastern Cape Province, South Africa. Afr. J. of Biotechnol., 4(12), 1458-1460.

Eyo, J.E., Ozougwu, J.C., Echi, P.C., 2011. Hypoglycaemic effects of Allium cepa, Allium sativum and Zingiber officinale aqueous extracts on alloxan-induced diabetic Rattus novergicus. Med. J. Islam World Acad. Sci. 19(3), 121-126.

Fagbohun, T.R., Odufunwa, K.T., 2010. Hypoglycaemic effect of methanolic extract of Anacardium occidentale leaves in alloxan-induced diabetic rats. Phsiol. Sci. 25, 87-90. 
Frimpong, E., Nlooto, M. 2019. Management of diabetes and hypertension among Zulu traditional health practitioners: A study of focus group interviews. Ethiop. J. Health Dev. 33(4), 219-228.

Gelfand, M., Mavi, S., Drummond, R.B., Ndemera, B., 1985. The traditional medical practitioner in Zimbabwe: his principles of practice and pharmacopoeia. Mambo Press.

Goedecke, J.H., Mtintsilana, A., Dlamini, S.N., Kengne, A.P. 2017. Type 2 diabetes mellitus in African women. Diabetes Res Clin Pract. 123, 87-96.

Guo, J.J., Han, J., Wang, S.L. and Liu, J.Y., 2017. An ethnobotanical survey of medicinal plants used for the ailment of diabetes mellitus in Changzhi city of Shanxi province, China. Biomed. Res. 28(3), 1370-1377.

Hashmi, M.A., Khan, A., Hanif, M., Farooq, U., Perveen, S., 2015. Traditional uses, phytochemistry and pharmacology of Olea europaea (Olive). EBCAM., 1-29.

Hutchings, A., Scott, A.H., Lewis, G., Cunningham, B., 1996. Zulu Medicinal Plants: An Inventory, $1^{\text {st }}$ ed. University of Natal Press, Pietermaritzburg, South Africa.

Hulley, I.M., Van Wyk, B-E. 2019. Quantitative medicinal ethnobotany of Kannaland (western Little Karoo, South Africa): Non-homogeneity amongst villages. S. Afr. J. Bot. 122, $225-265$.

International Diabetes Federation, 2015. IDF Diabetes Atlas. 7th ed., Brussels, Belgium, International Diabetes Federation. Available from http://www.diabetesatlas.org. Accessed 18 April 2020.

International Diabetes Federation, 2017. IDF Diabetes Atlas. 8th ed., Brussels, Belgium, International Diabetes Federation. Available from http://www.diabetesatlas.org. Accessed 21 April 2019

Joubert, J., Norman, R., Bradshaw, D., Goedecke, J.H., Steyn, N.P., Puoane, T., South African comparative risk assessment collaborating group, 2007. Estimating the burden of 
disease attributable to excess body weight in South Africa in 2000. S, Afr. Med. J. 97, 683-690.

Kamakura, R., Son, M.J., De Beer, D., Joubert, E., Miura, Y., Yagasaki, K. 2015. Antidiabetic effect of green rooibos (Aspalathus linearis) extract in cultured cells and type 2 diabetic model KK-Ay mice. Cytotechnology 67, 699-710.

Kengne, A.P., Echouffo-Tcheugui, J.B., Sobngwi, E., Mbanya, J.C., 2013. New insights on diabetes mellitus and obesity in Africa-part 1: prevalence, pathogenesis and comorbidities. Heart, 99, 979-983.

Keter, L.K., Mutiso, P.C., 2012. Ethnobotanical studies of medicinal plants used by Traditional Health Practitioners in the management of diabetes in Lower Eastern Province, Kenya. J. Ethnopharmacol. 139(1), 74-80.

Kandimalla, R., Thirumala, T., Reddy, P.H., 2017. Is Alzheimer's disease a Type 3 Diabetes? A critical appraisal. Biochim Biophys Acta Mol Basis Dis 1863 (5), 1078-1089.

Karthikeyan, S., Islam, M.S., 2016. New approaches for the treatment of diabetes and hypertension using herbal medicines in Phytotherapy in the Management of Diabetes and Hypertension An overview. Bentham Science Publishers United Arab Emirates.

Khan, A., Safdar, M., Khan, M.A., Khattak, K.N., and Anderson, R.A., 2003. Cinnamon improves glucose and lipids of people with type 2 diabetes. Diabetes Care 26, 32153218.

Khan, V., Najmi, A. K., Akhtar, M., Aqil, M., Mujeeb, M., and Pillai, K.K. 2011. A pharmacological appraisal of medicinal plants with antidiabetic potential. J. Pharm. Bioallied Sci. 4(1), 27-42.

Khumalo, G.O., 2018. An Inventory of the Most Popular Medicinal Barks Sold on Johannesburg Muthi Markets and the Antimicrobial Activity of Selected Extracts and Isolated Chemical Compounds. MSc dissertation, University of Johannesburg. 
King, M.W., 2014. Integrative Medical Biochemistry: Examination and Board Review. McGraw Hill Professional. Utopia Std by Cenveo, United States of America.

Klein, S., Sheard, N.F., Pi-Sunyer, X., Daly, A., Wylie-Rosett, J., Kulkarni, K., Clark, N.G., 2004. Weight management through lifestyle modification for the prevention and management of type 2 diabetes: rationale and strategies: a statement of the American Diabetes Association, the North American Association for the Study of Obesity, and the American Society for Clinical Nutrition. Diabetes Care 27(8), 2067-2073.

Kose, L.S., Moteetee, A., Van Vuuren, S., 2015. Ethnobotanical survey of medicinal plants used in the Maseru district of Lesotho. J. Ethnopharmacol., 170, 184-200.

Leylabadlo, H.E., Sanaie, S., Heravi, F.S., Ahmadian, Z., Ghotaslou, R., 2020. From role of gut microbiota to microbial-based therapies in type 2-diabetes. Infect Genet Evol 81, Article 104268.

Lipinski, C.A., 2004. Lead and drug-like compounds: the rule-of-five revolution. Drug Discov. Today: Technol. 1, 337-341.

Loots, D.T., Pieters, M., Islam, M.S., Botes, L. 2011. Antidiabetic effects of Aloe ferox and Aloe greatheadii var. davyana leaf gel extracts in a low-dose streptozotocin diabetes rat model., S. Afr. J. Sci. 107 (7/8), 532-537.

Macaulay, S., Ngobeni, M., Dunger, D.B., Norris, S.A., 2018. The prevalence of gestational diabetes mellitus amongst black South African women is a public health concern. Diabetes Res. Clin. Prac., 139, 278-287.

Mahwasane, S.T., Middleton, L., Boaduo, N., 2013. An ethnobotanical survey of indigenous knowledge on medicinal plants used by the traditional healers of the Lwamondo area, Limpopo Province, South Africa. S. Afr. J. Bot. 88, 69-75. 
Maiti, R., Jana, D., Das, U.K., Ghosh, D., 2004. Antidiabetic effect of aqueous extract of seed of Tamarindus indica in streptozotocin-induced diabetic rats. J. Ethnopharmacol. 92(1), $85-91$.

Malviya, N., Jain, S., Malviya, S.A.P.N.A., 2010. Antidiabetic potential of medicinal plants. Acta Pol. Pharm. 67(2), 113-118.

Mang, B., Wolters, M., Schmitt, B., Kelb, K., Lichtinghagen, R., Stichtenoth, D.O., Hahn, A., 2006. Effects of a cinnamon extract on plasma glucose, HbA 1c , and serum lipids in diabetes mellitus type 2. Europ. J. Clin. Invest. 36, 340-344.

Marles, R.J., Farnsworth, N.R., 1995. Antidiabetic plants and their active constituents. Phytomed. 1995, 2, 137-189.

Maruthur, N.M., Tseng, E., Hutfless, S., Wilson, L.M., Suarez-Cuervo, C., Berger, Z., Chu, Y., Iyoha, E., Segal, J.B., Bolen, S., 2016. Diabetes medications as monotherapy or metformin-based combination therapy for type 2 diabetes: A systematic review and meta-analysis. Ann. Intern. Med. 164(11), 740-751.

Matsabisa, M.G., Chukwuma, C.I., Chaudhary, S.K., 2019. South African traditional herbal formulation inhibits $\alpha$-glucosidase, DPP-IV and glycation activities, and modulates glucose utilisation in Chang liver cells and 3T3-L1 adipocytes. S. Afr. J. Bot. 121, 121127.

Mbanya, J.C.N., Motala, A., Sobngwi, E., Assah, F.K., Enoru, S. T., 2010. Diabetes in subSaharan Africa. The Lancet 375(973326), 2254-2266.

Mellem, J.J., 2013. Isolation and Characterization of the Leaves of Brachylaena discolor Extract as an Anti-diabetic Agent. Doctor of Technology (Food Technology) dissertation, Department of Biotechnology and Food Technology, Durban University of Technology. 
Mhlongo, L.S., Van Wyk, B-E., 2019. Zulu medicinal ethnobotany: new records from the Amandawe area of KwaZulu-Natal, South Africa. S. Afr. J. Bot. 122, 266-290.

Middha, S.K., Usha, T., Kiran, T.R., 2012. Influence of Punica granatum L. on region specific responses in rat brain during Alloxan-Induced diabetes. Asian Pac. J. Trop. Biomed. 2(2), S905-S909.

Moffett, R., 2010. Sesotho Plant and Animal Names and Plants used by the Basotho. African Sun Media. Free State, South Africa.

Mohammed, A., Ibrahim, M.A., Islam, M.S., 2014. African medicinal plants with antidiabetic potentials: A review. Planta Med. 80(05), 354-377.

Mohammed, A., Kumar, D., Rizvi.S.I., 2015. Antidiabetic potential of some less

commonly used plants in traditional medicinal systems of India and Nigeria. J Intercult Ethnopharmacol doi: 10.5455/jice.20141030015241.

Mogale, M.M.P., Raimondob, D.C, VanWyk, B-E., 2019. The ethnobotany of Central Sekhukhuneland, South Africa. S. Afr. J. Bot. 122, 90-119.

Moteetee, A., Van Wyk, B.E., 2011. The medical ethnobotany of Lesotho: a review. Bothalia, 41(1), 25-32.

Moteetee, A., Moffett, R.O., Seleteng-Kose, L., 2019. A review of the ethnobotany of the Basotho of Lesotho and the Free State Province of South Africa (South Sotho). S. Afr. J. Bot. 122, 21-56.

Mudaliar, S., Henry, R.R., 2001. New oral therapies for type 2 diabetes mellitus: the glitazones or insulin sensitizers. Annu. Rev. Med. 52(1), 239-257.

Mulaudzi, R.B., Aremu, A.O., Rengasamy. K.R.R., Adebayoa, S.A., McGawc, L.J., Amoo, S.O., Van Staden, J., Du Plooy, C.P., 2019. Antidiabetic, anti-inflammatory, anticholinesterase and cytotoxicity determination of two Carpobrotus species. S. Afr. J. Bot 125, 142-148. 
Muzumbukilwa, W.T., Nlooto, M., Owira, P.M.O., 2019. Hepatoprotective effects of Moringa oleifera Lam (Moringaceae) leaf extracts in streptozotocin-induced diabetes in rats. J. Funct. Foods 57, 75-82.

Nain, P., Saini, V., Sharma, S., Nain, J., 2012. Antidiabetic and antioxidant potential of Emblica officinalis Gaertn. leaves extract in streptozotocin-induced type-2 diabetes mellitus (T2DM) rats. J. Ethnopharmacol. 142(1), 65-71.

Ncube, B., Ndhlala, A.R., Okem, A., Van Staden, J. 2013. Hypoxis (Hypoxidaceae) in African traditional medicine. J. Ethnopharmacol., 150, 818-827.

Ndip, R.N., Taniha, N.F., Kuete, V. 2013. Antidiabetes Activity of African Medicinal Plants In Medicinal Plant Research in Africa: Pharmacology and Chemistry. Elsevier, Cameroon.

Ng, M,. Fleming, T., Robinson, M., Thomson, B., Graetz, N., Margono, C., Mullany, E.C., Biryukov, S., Abbafati, C., Abera, S.F., Abraham, J.P., Abu-Rmeileh, N.M.E., Achoki, T., AlBuhairan, F.S., Alemu, Z.A., Alfonso, R., Ali, M.K., Ali, R., Guzman, N.A., Ammar, W., Anwari, P., Banerjee, A., Barquera, S., Basu, S., Bennett, D.A., Bhutta, Z., Blore, J., Cabral, Nonato, I.C., Chang, J-C., Chowdhury, R., Courville, K.J., Criqui, M.H., Cundiff, D.K., Dabhadkar, K.C., Dandona, L., Davis, A., Dayama, A., Dharmaratne, S.D., Ding, E.L., Durrani, A.M., Esteghamati, A., Farzadfar, F., Fay, D.F.J., Feigin, V.L., Flaxman, A., Forouzanfar, M.H., Goto, A., Green, M.A., Gupta, R., Hafezi-Nejad, N., Hankey, G.J., Harewood, H.C., Havmoeller, R., Hay, S., Hernandez, L., Husseini, A., Idrisov, B.T., Ikeda, N., Islami, F., Jahangir, E., Jassal, S.K., Jee, S.H., Jeffreys, J., Jonas, J.B., Kabagambe, E.K., Khalifa, S.E.A.H., Kengne, A.P., Khader, Y.S., Khang, Y-H., Kim, D., Kimokoti, R.W., Kinge, J.M., Kokubo, Y., Kosen, S., Kwan, G., Lai, T., Leinsalu, M., Li, Y., Liang, X., Liu, S., Logroscino, G., Lotufo, P.A., Lu, Y., Ma J., Mainoo, N.K., Mensah, G.A., Merriman, T.R., Mokdad, 
A.H., Moschandreas, J., Naghavi, M., Naheed, A., Nand, D., Narayan, K.M.V., Nelson, E.L., Neuhouser, M.L., M.I., Ohkubo, T., Oti, S.O., Pedroza, A., Prabhakaran, D., Roy, N., Sampson, U., Seo, H., Sepanlou, S.G., Shibuya, K., Shiri, R., Shiue, I., Singh, G.M., Singh, J.A., Skirbekk, V., Stapelberg, N.J.C., Sturua, L., Sykes, B.L., Tobias, M., Tran, B.Z., Trasande, L., Toyoshima, H., Van de Vijver, S., Vasankari, T.J., Veerman, J.L., Velasquez-Melendez, G., Vlassov, V.V., Vollset, S.E., Vos, T., Wang, C., Wang, XR., Weiderpass, E., Werdecker, A., Wright, J.L., Yang, Y.C., Yatsuya, H., Yoon, J., Yoon, S-J., Zhao, Y., Zhou, M., Zhu, S., Lopez, A.D., Murray, C.J.L., Gakidou, E., 2013. Global, regional, and national prevalence of overweight and obesity in children and adults during 1980-2013: a systematic analysis for the Global Burden of Disease Study. Lancet, 384, 766-781.

Nkobole N., Houghton, P.J., Husseina, A., Lall, N., 2011. Antidiabetic activity of Terminalia sericea constituents. Nat Prod Commun 6(11), 1585-1588.

Nortje, J.M., Van Wyk, B.E., 2015. Medicinal plants of the Kamiesberg, Namaqualand, South Africa. J. Ethnopharmacol., 171, 205-222.

Odeyemi, S., Bradley, G., 2018. Medicinal plants used for the traditional management of diabetes in the Eastern Cape, South Africa. Molecules 23, 2759. doi:10.3390/molecules23112759.

Ogunmodede, O.S., Saalu, L.C., Ogunlade, B., Akunna, G.G., and Oyewopo, A.O., 2012. An evaluation of the hypoglycaemic, antioxidant and hepatoprotective potentials of onion (Allium cepa L.) on alloxan-induced diabetic rabbits. Internat. J. Pharmacol. 8(1), 2129.

Oguntibeju, O.O., 2019. Hypoglycaemic and anti-diabetic activity of selected African medicinal plants. Int J Physiol Pathophysiol Pharmacol 11(6), 224-237. 
Ojewole, J.A.O., 2005. Antinociceptive, anti-inflammatory and antidiabetic properties of Hypoxis hemerocallidea Fisch. \& C.A. Mey. (Hypoxidaceae) corm ['African Potato’] aqueous extract in mice and rats. J. Ethnopharmacol. 103, 126-134.

Ojewole, J.A.O., Adewumni, C.O., 2000. Hypoglycaemic effects of methanolic leaf extract of Catharanthus roseus (Linn) G. Don (Apocynaceae) in normal and diabetic mice. Acta Med. Biol. 48(2), 55-58.

Olaokun,O.O, Alaba, A.E., Ligege, K., Mkolo, N.M., 2020. Phytochemical content, antidiabetes, anti-inflammatory antioxidant andcytotoxic activity of leaf extracts of Elephantorrhiza elephantina (Burch.)Skeels. S. Afr. J. Bot. 128, 319-325.

Olatunji, L.A., Okwusidi, J.I., Soladoye, A.O., 2005. Antidiabetic effect of Anacardium occidentale stem-bark in fructose-diabetic rats. Pharm. Biol. 43(7), 589-593.

Oyedemi, S.O., Bradley, G., Afolayan, A.J., 2009. Ethnobotanical survey of medicinal plants used for the management of diabetes mellitus in the Nkonkobe municipality of South Africa. J. Med. Plants Res., 3(12), 1040-1044.

Oyedemi, S.O., Yakubu, M.T., Afolayan, A.J., 2010. Antidiabetic activities of aqueous leaves extract of Leonotis leonurus in streptozotocin induced diabetic rats. J. Med. Plants Res., $5(1), 119-125$.

Oyedemi, S., Bradley, G., Afolayan, A., 2012. Antidiabetic activities of aqueous stem bark extract of Strychnos henningsii Gilg in streptozotocin-nicotinamide type 2 diabetic rats. Iranian J. of Pharm. Res., 11(1), 221-228.

Oyedemi, S., Koekemoer, T., Bradley, G., Van de Venter, M., Afolayan, A., 2013. In vitro anti-hyperglycemia properties of the aqueous stem bark extract from Strychnos henningsii (Gilg). Int. J. Diabetes Dev. Ctries. 33(2),120-127.

Ozougwu, J.C. 2011. Anti-diabetic effects of Allium cepa (onions) aqueous extracts on alloxaninduced diabetic Rattus novergicus. J. Med. Plants Res. 5(7), 1134-1139. 
Peer, N., Kengne, A.P., Motala, A.A., Mbanya, J.C., 2014. Diabetes in the Africa region: an update. Diabetes Res. Clin. Pract. 103, 197-205.

Pereira, A.S.P., Den Haan, H., Peña-García, J., Moreno, M.M., Pérez-Sánchez, H., Apostolides, Z., 2019. Exploring African medicinal plants for potential anti-diabetic compounds with the DIA-DB Inverse Virtual ScreeningWeb Server. Molecules 24, 2002, doi:10.3390/molecules24102002.

Pham, A.Q., Kourlas, H., Pham, D.Q., 2007. Cinnamon supplementation in patients with type 2 diabetes mellitus. Pharmacother. 27(4), 595-599.

Pheiffer, C., Pillay-Van Wyk, V., Joubert, J.D., Levitt, N., Nglazi, M.D., Bradshaw, D., 2017. The prevalence of type 2 diabetes in South Africa: a systematic review protocol. BMJ Philander, L. A., 2011. An ethnobotany of Western Cape Rasta bush medicine. J Ethnopharmacol. 138, 578- 594.

Rasoulia, H., Yaranic, R., Pociotc, F., Popović-Djordjević, J., 2020. Anti-diabetic potential of plant alkaloids: Revisiting current findings and future perspectives. Pharmacol. Res. 155, 104723. doi.org/10.1016/j.phrs.2020.104723.

Rawi, S.M., Mourad, I.M., Sayed, D.A., 2011. Biochemical changes in experimental diabetes before and after treatment with mangifera indica and psidium guava extracts. Int. J. Pharm. Bio Sci. 2(2), 29-41.

Ryan, E.A., Pick, M.E., Marceau, C., 2001. Use of alternative medicines in diabetes mellitus. Diabetic Med. 18, 242-245.

Sagbo, I.J., Van de Venter, M., Koekemoer, T., Bradley, G., 2018. In vitro antidiabetic activity and mechanism of action of Brachylaena elliptica (Thunb.) DC. Evid. Based Complement. Alternat. Med. 4170372. doi: 10.1155/2018/4170372. 
Saidu, A.N., Mann, A., Balogun, S., 2012. The hypoglycemic effect of aqueous extract of the Anacardium occidentale Linn leaves grown in Nigeria on normoglycemic albino rats. J. Emerg.Trends Engineer. Appl. Sci. 3(2), 302-308.

Sangi, S.M., Sulaiman, M.I., El-wahab, M.F., Ahmedani, E.I., Ali, S.S., 2015. Antihyperglycemic effect of thymoquinone and oleuropein, on streptozotocin-induced diabetes mellitus in experimental animals. Pharmacogn. Mag., 11(Suppl 2), S251.

Seetaloo, A.D., Aumeeruddy, M.Z., Kannan, R.R.R., Mahomoodally, M.F., 2019. Potential of traditionally consumed medicinal herbs, spices, and food plants to inhibit key digestive enzymes geared towards diabetes mellitus management - A systematic review. S. Afr. J. Bot. 120, 3-24.

Semenya, S., Potgieter, M., Erasmus, L., 2012. Ethnobotanical survey of medicinal plants used by Bapedi healers to treat diabetes mellitus in the Limpopo Province, South Africa. J. Ethnopharmacol. 141(1), 440-445.

Shafrir, E., 1996. Development and consequences of insulin resistance: lessons from animals with hyperinsulinaemia. Diabetes Metab. 22(2), 122-131.

Singh, S.N., Vats, P., Suri, S., Shyam, R., Kumria, M.M.L., Ranganathan, S., Sridharan, K., 2001. Effect of an antidiabetic extract of Catharanthus roseus on enzymic activities in streptozotocin induced diabetic rats. J. Ethnopharmacol. 76, 269-277.

Singh, M.P, Pathak, K., 2015. Animal models for biological screening of anti-diabetic drugs: An overview. Eur. J. Exp. Biol. 5(5), 37-48.

Stack, T., 2008. Metformin: A review. Drugs Today, 44(4), 303-314.

Street, R.A., Stirk, W.A., Van Staden, J., 2008. South African traditional medicinal plant tradechallenges in regulating quality, safety and efficacy. J. Ethnopharmacol. 119(3), 705710. 
Street, R.A., Prinsloo, G., 2012. Commercially important medicinal plants of South Africa: A review. J. Chem. 2013, 205048. doi.org/10.1155/2013/205048.

Soetedjo, N.N., McAllister, S.M., Ugarte-Gil, C., Firanescu, A.G., Ronacher, K., Alisjahbana, B., Costache, A.L., Zubiate, C., Malherbe, S.T., Koesoemadinata, R.C., Laurence, Y.V., 2018. Disease characteristics and treatment of patients with diabetes mellitus attending government health services in Indonesia, Peru, Romania and South Africa. Trop. Med. Int. Health 23(10), 1118-1128.

Sokeng, S.D., Lontsi, D., Moundipa, P.F., Jatsa, H.B., Watcho, P., and Kamtchouing, P., 2007. Hypoglycemic effect of Anacardium occidentale L. methanol extract and fractions on streptozotocin-induced diabetic rats. Global J. Pharmacol. 1(1), 1-5.

Song, R., 2016. Mechanism of metformin: a tale of two sites. Diabetes Care 39(2), 187-189.

Steyn, K., Kazenellenbogen, J.M., Lombard, C.J., Bourne, L.T., 1997. Urbanization and the risk for chronic diseases of lifestyle in the black population of the Cape Peninsula, South Africa. J. Cardiovasc. Risk 4, 135-142.

Tag, H., Kalita, P., Dwivedi, P., Das, A.K., Namsa, N.D., 2012. Herbal medicines used in the treatment of diabetes mellitus in Arunachal Himalaya, northeast, India. J. Ethnopharmacol. 141(3), 786-795.

Taj Eldin, I.M., Ahmed, E.M., Abd Elwahab, H.M., 2010. Preliminary study of the clinical hypoglycemic effects of Allium cepa (red onion) in type 1 and type 2 diabetic patients. Environ. Health Insights (4), 71-77.

The Plant List. A Working List of All Plant Species. Available from http://www.theplantlist.org/tpl1.1/search? Accessed 11 May 2020.

Tonascia, S., Meinert, C.L., 1986. Clinical Trials: Design, Conduct, and Analysis. Oxford University Press, UK. 
Toserkani, A., Jalali, M.R., and Najafzaheh, H., 2012. Changes of lipid profiles, glucose, and hemogram after administration of Ruta graveolens extract in diabetic rats. Comp. Clin. Pathol. 21, 1587-1592.

Thring, T.S.A., Weitz, F.M., 2006. Medicinal plant use in the Bredasdorp/Elim region of the Southern Overberg in the Western Cape Province of South Africa. J. Ethnopharmacol. $103,261-275$.

Ukwenya, V.O., Ashaolu, J.O., Adeyemi, D.O., Akinola, O., Caxton-Martins, E., 2012. Antihyperglycemic activities of methanolic leaf extract of Anacardium occidentale (Linn.) on the pancreas of streptozotocin-induced diabetic rats. J. Cell Anim. Biol. 6(14), 207-212.

Upendra Rao, M., Sreenivasulu, M., Chengaiah, B., Jaganmohan Reddy. K., Madhusudhana Chetty, C., 2010. Herbal medicines for diabetes mellitus: A review. Int. J. PharmTech. Res., 2(3), 1883-1892.

Upton, R., 2013. Stinging nettles leaf (Urtica dioica L.): Extraordinary vegetable medicine. J. Herbal Med. 3(1), 9-38.

Van de Venter, M., Roux, S., Bungu, L.C., Louw, J., Crouch, N.R. Grace, O.M., Maharaj, V, Pillay, P., Sewnariane, P., Bhagwandin, N., Folb, P., 2008. Antidiabetic screening and scoring of 11 plants traditionally used in South Africa. J. Ethnopharmacol. 119, 81-86. Van Huyssteen, M., Milne. P.J., Campbell, E.E., Van de Venter, M., 2011. Antidiabetic and cytotoxicity screening of five medicinal plants used by traditional African health practitioners in the Nelson Mandela Metropole, South Africa. Afr J Tradit Complement Altern Med. 8(2), 150-158.

Van Wyk, B.E., Oudtshoorn, B.V., Gericke, N., 1997. Medicinal Plants of South Africa. Briza Publications, South Africa. 
Van Wyk, B.E., De Wet, H., Van Heerden, F. R., 2008. An ethnobotanical survey of medicinal plants in the southeastern Karoo, South Africa. S. Afr. J. Bot. 74, 696-704.

Van Wyk, B-E., Gorelik, B., 2017. The history and ethnobotany of Cape herbal teas. S. Afr. J. Bot. 110, 18-38.

Van Wyk, B-E., 2020. A family-level floristic inventory and analysis of medicinal plants used in Traditional African Medicine. J. Ethnopharmacol. 249, 112351.

Von Koenen, E., 1996. Medicinal, Poisonous, and Edible Plants in Namibia, $1^{\text {st }}$ ed. Klaus Hess Publishers, Windhoek, Namibia.

Vorster, H.H., Venter, C.S., Wissing, M.P., Margetts, B.M., 2005. The nutrition and health transition in the North West Province of South Africa: a review of the THUSA (Transition and Health during Urbanisation of South Africans) study. Public Health Nutrit. 8, 480-490.

Watt, J.M., Breyer-Brandwijk, M.G., 1962. The Medicinal and Poisonous Plants of Southern and Eastern Africa, 2nd ed. Livingstone, Edinburg and London.

World Health Organisation, 2016. Global Report on Diabetes. Geneva. Available from https://www.who.int/diabetes/global-report/en/. Accessed 18 April 2020.

World Health Organisation. Diabetes, 2019. Factsheet on Diabetes 2019, Available from https://www.who.int/news-room/fact-sheets/detail/diabetes. Accessed 21 April 2019.

Yassa, H.D., Tohamy, A.F., 2014. Extract of Moringa oleifera leaves ameliorates streptozotocin-induced diabetes mellitus in adult rats. Acta Histochemica., 116(5), 844854.

Yusuf, U.A., Adeeyo, O.A., Salawu, E.O., Enaibe, B.U., Omotoso, O.D., 2012. Allium cepa protects renal functions in diabetic rabbit. World J. Life Sci. Med. Res. 2(2), 86-90.

Zimmet, P., Alberti, K.G.M.M. and Shaw, J., 2001. Global and societal implications of the diabetes epidemic. Nature, 414(6865), 782-787. 
